AMANDA OLIVOTTI FERREIRA

\title{
Obtenção e caracterização de células do broto hepático de ratos para terapia celular
}




\section{Obtenção e caracterização de células do broto hepático de ratos para terapia celular}

Dissertação apresentada ao Programa de Pós-Graduação em Anatomia dos Animais Domésticos e Silvestres da Faculdade de Medicina Veterinária e Zootecnia da Universidade de São Paulo para obtenção do título de Mestre em Ciências

Departamento:

Cirurgia

Área de concentração:

Anatomia dos Animais Domésticos e Silvestres

Orientadora

Dra. Rose Eli Grassi Rici

São Paulo

2011 
Autorizo a reprodução parcial ou total desta obra, para fins acadêmicos, desde que citada a fonte.

DADOS INTERNACIONAIS DE CATALOGAÇÃO-NA-PUBLICAÇÃO

(Biblioteca Virginie Buff D’Ápice da Faculdade de Medicina Veterinária e Zootecnia da Universidade de São Paulo)

Ferreira, Amanda Olivotti

FMVZ Obtenção e caracterização de células do broto hepático de ratos para terapia celular / Amanda Olivotti Ferreira. -- 2011. $135 \mathrm{f}$. : il.

Dissertação (Mestrado) - Universidade de São Paulo. Faculdade de Medicina Veterinária e Zootecnia. Departamento de Cirurgia, São Paulo, 2011.

Programa de Pós-Graduação: Anatomia dos Animais Domésticos e Silvestres.

Área de concentração: Anatomia dos Animais Domésticos e Silvestres.

Orientador: Dra. Rose Eli Grassi Rici.

1. Células-tronco embrionária e fetal. 2. Broto hepático. 3. Citometria de fluxo. 4. Transaminases hepáticas. 5. Peroxidação lipídica. I. Título. 


\section{CERTIFICADO}

Certificamos que o Projeto intitulado "Isolamento, cultivo e diferenciação de células do broto hepático para utilização em terapia celular", protocolado sob o n $1377 / 2008$, utilizando 40 (quarenta) camundongos, sob a responsabilidade da Profa. Dra. Maria Angélica Miglino, está de acordo com os princípios éticos de experimentação animal da Comissão de Bioética da Faculdade de Medicina Veterinária e Zootecnia da Universidade de São Paulo e foi aprovado na reunião do dia 23 de abril de 2008 .

We certify that the Research "Isolation, culture and differentiation of stem cells from the hepatic bud for cellular therapy utilization", utilizing 40 (forty) mice, protocol number 1375/2008, under the responsibility Profa. Dra. Maria Angélica Miglino, agree with Ethical Principles in Animal Research adopted by Bioethic Commission of the School of Veterinary Medicine and Animal Science of University of São Paulo and was approved in the meeting of day 04/23/08.

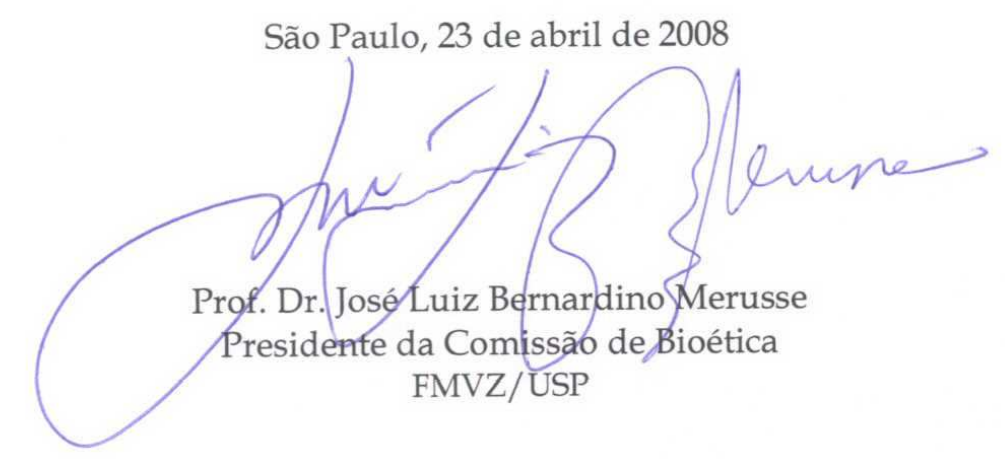




\section{FOLHA DE AVALIAÇÃO}

Nome: FERREIRA, Amanda Olivotti

Título: Obtenção e caracterização de células do broto hepático de ratos para terapia celular

Dissertação apresentada ao Programa de Pós-Graduação em Anatomia dos Animais Domésticos e Silvestres da Faculdade de Medicina Veterinária e Zootecnia da Universidade de São Paulo para obtenção do título de Mestre em Ciências

Data:

\section{Banca Examinadora}

Prof.Dr Instituição:

Assinatura: Julgamento:

Prof. Dr. Instituição:

Assinatura: Julgamento:

Prof. Dr. Instituição:

Assinatura: Julgamento: 


\section{DEDICATÓRIA}

Em todos os momentos importantes da minha vida, ela sempre esteve por perto Abdicando de diversas coisas por mim.

Muitas vezes aquilo foi sacrificante, mas ela nunca deixou transparecer.

Sempre demonstrou estar segura e forte para passar por qualquer obstáculo Nunca se permitiu fracassar nem desistir, por isso sempre foi a minha fortaleza.

Passamos por tantas coisas juntas

Fomos unidas como irmãs, confidentes e melhores amigas

Divertimo-nos muito e aprontamos " várias"!

Vibramos uma com a vitória da outra,

Sempre juntando forças para sair em busca de uma vida melhor.

Ela sofreu comigo todas as minhas angústias,

Enxugou todas as minhas lágrimas,

Nunca me deixou desistir dos meus sonhos.

Ensinou-me que na vida é preciso ter garra para vencer os desafios

Que algumas coisas são difíceis, mas não impossíveis.

Que é preciso ter esperança e fé para acreditar que tudo ficará melhor.

Hoje vejo que a sua força e o seu amor guiaram-me pela vida,

Dando-me as asas de que precisava para voar.

Agradeço todos os dias a Deus por ter me dado o presente de fazer parte da vida dela

Por todas essas razões que dedico todo este trabalho

Ao maior bem da minha vida,

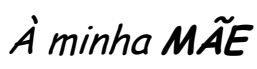

Sylvia Helena Olivotti Ferreira 


\section{AGRADECIMENTOS}

- Ao meu pai José Carlos, que, mesmo com toda simplicidade e ingenuidade, sempre me apoiou em tudo. Ele sempre foi o meu exemplo de humildade, bondade e caráter; aquele que me ensinou a amar os animais.

- Ao meu irmão Leonardo e ao meu querido amigo Rodrigo, que foram sempre meus exemplos de dedicação, profissionalismo e trabalho.

- Ao meu avô Jair (in memorian), por ter me ensinado a importância do estudo e da determinação. Mostrou-me, com toda sua inteligência, que os livros são a melhor forma de se conhecer o mundo.

- À minha avozinha Landina (in memorian), por todo imenso amor de Vó que tive presente durante minha vida. Agradeço demais a todas as lições de vida e ensinamentos. Realmente, ajudaram a me tornar a pessoa que sou, afinal, grande parte de mim vem dela; da sua doçura, da sua delicadeza, da sua grandeza, da imensa mulher que foi sempre dedicada a ajudar ao próximo e tratando a todos como irmãos. Só me deixou a árdua tarefa de compreender o significado da palavra morte e o pior de tudo, aprender a conviver com a palavra saudade. Minha vozinha sempre será a minha mais bela lembrança. "Mãezinha, eu quero te ver lá no céu..."

- Ao Conrado, por todo companheirismo, carinho, dedicação, apoio em tudo e ajuda sempre. Por me conhecer e me aceitar com todos os meus defeitos. Obrigada pela imensa ajuda nesta etapa importante da minha vida e por compreender tudo que estou passando.

- A toda minha família, minha avó Rosinha, meus tios, tias e primas.

- Às minhas amigas Cris e Patinha, pelo apoio, torcida, por toda conversa paralela, pelas muitas risadas e situações engraçadas. Por tudo que passamos juntas, amigas do peito grande! 
- Ao Caio, José Roberto e Tânia, pelo abrigo, força e carinho. Obrigada por tudo! Sem a ajuda de vocês não teria conseguido chegar até aqui. E Obrigada ao Fumaça Roberto por todas as lembranças divertidas que levarei para o resto de minha vida!

- À minha amiga Elaine Cristina Aparecida, por todas as risadas, confidências, regimes loucos, carinho, paciência e pelo imenso companheirismo.

- Aos meus Caros amigos Dilayla Kelly Cristina e Sarmentinho, pela diversão e companheirismo no nosso Lar.

- Aos meus amigos Lucas José Botelho, pelo seu charme e simpatia; Arthur Cássio Paraíbas, por ser bisneto de Lampião e ao Best pela força e momentos divertidos.

- Ao meu "primeiro" orientador Dr. Alex Sander Machado, pela oportunidade de conhecer a Universidade de São Paulo e, principalmente, Cabo Polônio no Uruguai. Por me ensinar a ter paixão pelo o que faço. Agradeço por me mostrar bons caminhos.

- Ao Prof. Dr. Ricardo Romão Guerra, por todas as oportunidades, pela paciência em todos os momentos. Obrigada pela ajuda nos momentos difíceis. Agradeço por me ensinar a caminhar.

- À minha Orientadora Dra. Rose Eli Grassi Rici, pela atenção, ajuda e colaboração neste projeto. Obrigada por dividir comigo este momento e por todos os dias que ficamos loucas juntas.

- Ao Prof. Dr. José Roberto kfoury Jr, pelo apoio a mim dado na orientação inicial deste projeto. E por me permitir usar o seu laboratório para a realização do experimento.

- À Profa. Dra Maria Angélica Miglino, pela oportunidade a mim dada neste departamento. Por todos os ensinamentos durante as aulas e reuniões. Por se mostrar sempre com entusiasmo ao fazer ciência, buscando, infinitamente, por novas descobertas.

- À Dra. Norma e Ms. Dayane Alcântara, pelos ensinamentos, paciência e ajuda. Ser-lhes-ei eternamente grata. Sem dúvida, fazem grande parte desta conquista. 
- Às amigonas Fernanda Faião e Mirian, pela imensa ajuda na realização dos experimentos e pela paciência em me ensinar.

- Ao amigo Bruno José, por todas as noites acordados para formatar este trabalho. Obrigada pelas referências e risadas!

- Ao técnico de laboratório Ronaldo Agostinho, que mesmo tendo aquele "jeitão bruto" de ser, sempre me ajudou em tudo, mostrando-se um amigão durante todo o período que estive aqui, desde que entrei como estagiária até o término deste mestrado. Muita coisa que sei aprendi com ele. Obrigada!

- À recepcionista Jaqueline, uma "belezinha" de pessoa que torna o ambiente de trabalho confortante e agradável. Sempre pró-ativa para ajudar.

- À Dra. Janaína Monteiro, por ter me ajudado na realização do projeto, sempre disposta a ajudar.

- Ao Augusto, Maicon, Diogo, Índio por toda ajuda a mim dada durante esta jornada.

- Aos colegas de trabalho Joãozinho, Matheus, Marcolino, Bruno Estrupício, Letícia, Renata, Drika, André (Bebel), Márcio, Marina, Greyson, Thaís, Manaus, Bragança, Aline, Maumau, Álvaro, Sônia, Rose Bosh, Paula, Catarina, Atanásio, Valdir (Alfredo) que sempre estavam presentes no dia-a-dia de uma pós-graduação divertida.

- A todos os outros funcionários, professores e colegas que diretamente ou indiretamente participaram da realização de meu trabalho.

- A CAPES pelo apoio financeiro.

- E por fim, UM BIG AGRADECIMENTO a todos os ratos Fischer (in memorian), que tornaram esse projeto realidade. A vida de todos não será em vão. Espero do fundo coração, que todos estejam abençoados e protegidos por São Francisco de Assis. E se puderem me perdoem. 


\section{AGRADECIMENTO MAIS QUE ESPECIAL}

- Ao inesquecível Prof. Dr. Durvanei Augusto Maria, por todo carinho, atenção, cuidado, amizade, pela orientação em todo o processo. Por todos os momentos divertidos deste período, pelas muitas risadas e cafezinhos ao longo do dia. Obrigada por ter acreditado em $\operatorname{mim} e$ por todos os ensinamentos que levarei para o resto da minha vida. Agradeço por ter estado comigo nesta caminhada. Sem dúvida, um dos maiores exemplo de bondade, competência e acima de tudo alegria de viver!!! "... dançando lambada ê... dançando lambada ah..." 
"A alegria não está nas coisas, está em nós" 


\section{RESUMO}

FERREIRA, A. O. Obtenção e caracterização de células do broto hepático de ratos para terapia celular. [Obtaining and characterization of strains of cells of the liver of rats to bud stem cells]. 2011.135f. Dissertação (Mestrado em Ciências) Faculdade de Medicina Veterinária e Zootecnia. Universidade de São Paulo, São Paulo, 2011.

As células-tronco são capazes de se diferenciarem em praticamente todos os tipos celulares, podendo ser utilizadas em terapias de substituição em várias doenças. Células de linhagens hepáticas embrionárias e fetais pode ser uma fonte importante para a terapia celular em indivíduos com doenças hepáticas, pois possuem um alto índice de diferenciação em hepatócitos e células do ducto biliar. O objetivo deste trabalho foi avaliar o potencial e o controle da resposta proliferativa de células do broto hepático de ratos Fischer 344 em cultura. A obtenção das células do broto hepático foi realizada nos períodos 12,5; 14,5 e 16,5 dias de gestação e os fragmentos foram cultivados em meio DMEM-F12. A caracterização morfológica foi realizada em microscopia invertida de luz e eletrônica de varredura. A caracterização dos marcadores de células mesenquimais, do citoesqueleto, progressão e fases do ciclo celular, morte celular, e do potencial elétrico mitocondrial foram realizadas por citometria de fluxo. A função bioquímica foi realizada pela análise das transaminases hepáticas e pela produção de radicais livres lipoperoxidados. Os resultados encontrados no acasalamento dos ratos isogênicos da linhagem Fischer 344 seguiu o protocolo de $12 \mathrm{~h}$ de luz, alcançando o índice reprodutivo satisfatório e reprodutível. $\mathrm{O}$ isolamento e separação do broto hepático desta linhagem de ratos permitiu a obtenção, expansão e caracterização de uma cultura primária nos diferentes dias de gestação 12,5; 14,5 e 16,5. Os aspectos morfológicos encontrados foram de células fusiformes do tipo fibroblast-like para todos os períodos de gestação em cultura. As análises das transaminases hepáticas TGO e TGP, mostraram se em concentrações menores no período 12,5 dias de gestação. A expressão dos marcadores de células-tronco de origem mesenquimais (CD90, Nanog, Oct 3/4 e STRO1), marcadores do citoesqueleto (CK8, CK18 e Desmina), marcadores envolvidos na checagem e progressão do ciclo celular (P53, P21, P27 e Ciclina D1) e marcadores envolvidos na morte celular (Anexina V/PI, Caspase 3, Bax, Bad e Bcl2) mostraram diferencialmente expressos, nos diferentes períodos gestacionais. A análise do potencial elétrico mitocondrial nos períodos de gestação de 14,5 e 16,5 dias, foi maior na proporção de células inativas com menor capacidade funcional ou metabólica, quando comparada ao período de 12,5 dias ou mesmo em relação ao hepatócito normal de um rato adulto. Análise das fases do ciclo celular observou-se uma concentração de célula na fase G0/G1, repercutindo na modulação da capacidade de proliferação e aumento na proporção de células com DNA fragmentado, nas CBH no período de 16,5 dias em comparação aos demais períodos e ao hepatócito normal. O aumento da fragmentação do DNA em média de 3,5 e 2,3 vezes, respectivamente nos períodos de 12,5 e 14,5 dias de gestação. A capacidade de síntese e de divisão celular das $\mathrm{CBH}$ foi mantida em todos os períodos de gestação. Os radicais livres lipoperoxidados mostraram quantidades insignificantes em CBH nos diferentes dias de gestação.

Palavras Chaves: Células-tronco embrionária e fetal. Broto hepático. Citometria de fluxo. Transaminases hepáticas. Peroxidação lipídica. 


\section{ABSTRACT}

FERREIRA, A. O. Obtaining and characterization of strains of cells of the liver of rats to bud stem cells. [Obtenção e caracterização de células do broto hepático de ratos para terapia celular]. 2011.135f. Dissertação (Mestrado em Ciências) Faculdade de Medicina Veterinária e Zootecnia. Universidade de São Paulo, São Paulo, 2011.

Stem cells are able to differentiate into virtually all cell types and can be used in replacement therapies in various diseases. Cells of embryonic and fetal liver lines can be an important source for cell therapy in patients with liver disease because they have a high rate of differentiation into hepatocytes and biliary duct cells. The aim of this study was to evaluate the potential and control of the proliferative response of liver bud cells during the maturation of hepatocytes in culture. The acquirement of liver bud cells was performed for 12.5, 14.5 and 16.5 days of gestation and the fragments were cultured in DMEM-F12. Morphological characterization was performed on inverted light microscopy and scanning electron microscopy. The characterization of mesenchymal cell markers, cytoskeleton, and progression stages of the cell cycle, cell death and mitochondrial electric potential were performed by flow cytometry. The biochemical function was performed by analysis of liver transaminases and the production of free radicals lipoperoxidados. The results found in rats' mating isogenic Fischer 344 followed the protocol of 12 hours of light reaching the reproductive rate satisfactory. The isolation and separation of the liver bud of this strain of mice allowed the isolation, expansion and characterization of a primary culture at different days of gestation, 12.5, 14.5 and 16.5 days. The morphological features were found of spindle cell type to fibroblast-like cells of the liver bud in culture. Analyses of hepatic transaminases GOT and GPT showed lower concentrations in the period 12.5 days of gestation. The expression of stem cell markers of mesenchymal origin (CD90, Nanog, Oct STRO1 and 3/4), cytoskeletal markers (CK8, CK18 and desmin) markers involved in checking and cell cycle progression (P53, P21, P27 and Cyclin D1) and markers involved in apoptosis (Annexin V / PI, caspase 3, Bax, Bad and Bcl2) showed differentially expressed in different gestational periods. In the analysis of mitochondrial electrical potential in the gestation periods of 14.5 and 16.5 days, it was observed the higher proportion of quiescent cells with lower metabolic of functional capacity when compared to the periodo of 12.5 days or even compared to a normal hepatocyte adult rat. In the analysis of cell cycle phases it was observed the concentration of cell in the G0/G1 phase, resulting in modulation of proliferation capacity and the increase in the proportion of cells with fragmented DNA, CBH in the period 16.5 days compared to other periods and the normal hepatocyte. The increase of DNA fragmentation on average 3.5 and 2.3 times respectively in the periods of 12.5 and 14.5 days of gestation. The synthesis and cellular division of $\mathrm{CBH}$ was maintained in all stages of pregnancy. The free radicals lipoperoxidados showed insignificant amounts of $\mathrm{CBH}$ in the days of gestation.

Keywords: Embryonic stem cells and fetal. Liver bud. Flow cytometry. Liver transaminases. Lipid peroxidation. 


\section{LISTA DE ABREVIATURAS}

$\begin{array}{ll}\text { AFP } & \text { alfa-fetoproteína } \\ \text { ALB } & \text { albumina } \\ \text { ALT } & \text { alamina amino transferase }\end{array}$

Anexina V/PI indicam morte celular por apoptose (Anexina V) ou necrose (PI)

AST aspartato amino transferase

APAF-1 apoptotic protease fator ativador de 1

BAX proteínas pró- apoptóticas

BAD proteínas pró-apoptóticas

BCL-2 proteínas anti-apoptótica, pois inibe a liberação do citocromo-c

BG-250 Coomassie brilliant blue

BMP proteínas morfogenéticas do osso

BSA soro albumina bovina

Caspase 3 indica morte celular por apoptose

CBH células do Broto Hepático

Ciclina D1 proteína reguladores das CKK's (quinases dependente de ciclinas), envolvidas na fase G1/S.

CD grupo de diferenciação

CD18 Integrina beta-2

CD34 reage com células progenitoras hematopoiéticas e endoteliais da medula óssea.

CD45 proteína tirosina fosfatase, comum em leucócitos e outras células hematopoéticas diferenciadas.

CD90 antígeno de superfície celular Thy-1.

CD271 receptor de baixa afinidade para o fator de crescimento P75

CITED 2 interacting transativador 2

CK citoqueratinas

CK 8 citoqueratina 8, baixo peso molecular, anticorpo monoclonal marca as células epiteliais não escamosas.

CK18 citoqueratinas 18 de baixo peso molecular, marca células do epitélio ductal e glandular. 
Desmina marcador de células musculares lisas, estriadas cardíacas e esqueléticas.

DMEM/F12 Dulbecco's Modified Eagle Médium Nutrient Mixture F-12 Ham

DMSO dimetilsulfóxido

DNA ácido desoxirribonucleico

DP desvio padrão

FGF fatores de crescimento de fibroblastos

FITC isotiocianato de fluoresceína

HGF fator de crescimento hepático

HNF fatores de transcrição nuclear

Hyclone soro fetal bovino com alto grau de pureza e qualidade

LPO lipoperoxidação

MDA malondialdeído

MEC matriz extracelular

$\mathrm{mL} \quad$ mililitro

mM milimolar

$\mathrm{mol} / \mathrm{L} \quad$ moléculas por litro

MTT 3-[(4,5- dimethylthiazol-2-yl)-2,5- diphenyltetrazolium bromide])

n número de amostras analisadas

$\mathrm{NaCl} \quad$ cloreto de sódio

Nanog determinante de células-tronco embrionárias e germinativas são fatores de transcrição envolvidos na regulação da supressão de genes que levam a diferenciação e manutenção da pluripotência

nm nanômetro

nM nanomol

OCT3/4 fator de transcrição de células-tronco embrionárias e germinativas pluripotentes

P21 proteínas envolvidas na progressão do ciclo celular, reguladora da transição da fase G1-S e G2-M

P27 proteínas envolvidas na progressão do ciclo celular, reguladora da transição da fase G1-S e G2-M

P53 atua impedindo a progressão do ciclo celular na transição $\mathrm{G} 1 / \mathrm{S}$, na presença de danos à molécula de DNA

PBS Solução tampão fosfato de sódio 


\begin{tabular}{ll} 
pH & potencial hidrogeniônico \\
PI & iodeto de propídio \\
RNAse & ribonuclease \\
RPM & rotações por minuto \\
STRO 1 & do inglês, stroma cell surface antigen 1 \\
SFB & soro fetal bovino \\
TBA & ácido tiobarbitúrico \\
TBARS & substâncias relativas do ácido tiobarbitúrico \\
TCA & ácido tricloroacético \\
TGO & transaminases Glutâmico Oxalacética \\
TGP & transaminases Glutâmico Pirúvica \\
TNF & fator de necrose tumoral \\
TRK & receptor tirosina quinase \\
U & unidade \\
ug/mL & unidade grama por mililitro \\
uL & unidade litro \\
V/L & volume por litro \\
\hline
\end{tabular}

VCAM-1 molécula de adesão vascular 1 


\section{LISTA DE FIGURAS}

Figura 1 - Características morfológicas de apoptose e necrose.

Figura 2 - Representação simplificada das duas principais vias envolvidas na apoptose.

Figura 3 - Esquema ilustrativo das fases do ciclo celular, onde: G0- repouso; G1 Produção de enzimas necessárias para produção de outras proteínas e RNA; S- síntese de DNA; G2- período pré-mitótico; MMitose.

Figura 4 - Fotografia de rato da linhagem isogênica Fischer 344. A e B:aspecto do animal adulto e C: laparotomia exploratória da rata prenhe de 14.5 dias de estação.

Figura 5 - Isolamento do embrião de rato Fischer 344. A, B e C- Embriões de 12,5 dias após o acasalamento isolados da placenta. C- Embrião isolado de 12,5 dias e C'- Broto hepático isolado do embrião. 59

Figura 6 - Isolamento do embrião de ratos da linhagem Fischer 344. A- Fetos com 16,5 dias após fecundação. B e C- Embriões em CBH 12,5 dias após o acasalamento 72

Figura 7 - Broto hepático de um embrião de rato Fischer 344 12,5 dias após o acasalamento. Nota-se presença de 4 segmentos estando 2 segmentos de cada lado do embrião. O broto hepático neste período gestacional encontra-se logo abaixo do coração como evidenciado na foto $\left(^{*}\right)$....... 73

Figura 8 - Feto de rato da linhagem Fischer 344, a fresco de 14,5 dias de gestação. Nota-se em detalhe o fígado isolado. 
Figura 9 - Fotomicrografias de microscópio invertido representativas das células do broto hepático de ratos Fischer 344, onde A: CBH 12,5, B e C: CBH 14,5 dias e CBH 16,5 dias de gestação. Aumento de 20x

Figura 10- Fotomicrografias obtida em microscópico invertido evidenciando a morfologia das células dos brotos hepático do embriões de ratos em seus diferentes dias de gestação. A e D (CBH12,5 dias), B e E (CBH 14,5dias) e $C$ e $F$ (CBH 16,5 dias). 40x.Coloração Hematoxilinaeosina.

Figura 11 - Fotomicrografia da microscopia eletrônica de varredura das células do broto hepático de ratos Fischer nos períodos 12,5 dias (figura A e B) setas amarelas e 14,5dias (figura $C$ e vermelhas.

Figura 12- Fotomicrografia da microscopia eletrônica de varredura das células do broto hepático de ratos nos períodos de 16,5 dias (setas brancas) Notase detalhes da organização da monocamanda de células e fibras da matriz extracelular.

Figura 13- Histograma representativo do potencial elétrico mitocondrial. Curva preta - controle de fluorescência ; curva verde - CBH 16,5 dias; curva vermelho - $\mathrm{CBH} 14,5$ dias ; curva roxa . $\mathrm{CBH} 12,5$ dias

Figura 14 - Histogramas das curvas (overlay) da distribuição do conteúdo do DNA nas diferentes fases do ciclo celular das células do broto hepático de ratos Fischer 344. Em destaque aumento da proporção de células com DNA fragmentado em células CBH 16,5 dias e aumento de proporção de células em divisão celular G2/M 


\section{LISTA DE GRÁFICOS}

Gráfico 1 - Gráfico contendo os índices reprodutivos das ratas da linhagem Fischer 344 à medida que foi modificado o fotoperíodo da fêmea e/ou do macho.

Gráfico 2 - Gráfico de barras representando os valores de média tDP para os valores de TGO (U/L) das células $\mathrm{CBH}$ nos diferentes dias de gestação em comparação ao hepatócito de rato normal

79

Gráfico 3 - Gráfico de barras representando os valores de média \pm DP para os valores de TGP (U/L) das células $\mathrm{CBH}$ nos diferentes dias de gestação em comparação ao hepatócito de rato normal

Gráfico 4 - Gráfico de barras representando os valores de média \pm DP para os marcadores de células mesenquimais expressos em células do broto hepático nos diferentes dias de gestação obtidos por citometria de fluxo.

82

Gráfico 5 - Gráficos dot plot representativo obtido por citometria de fluxo para os marcadores mesenquimais CD90 (A), NANOG (B), OCT3/4 (C) e STRO1 (D), em células do broto hepático de ratos Fischer 344 nos períodos 12,5; 14,5 e 16,5 dias. Adquiridas pelo programa CellQuestPro e analisado no programa WinMDI2.9.

Gráfico 6 - Gráfico de barras representando os valores de média \pm DP para os marcadores de citoesqueleto expressos em células do broto hepático nos diferentes dias de gestação obtidos por citometria de fluxo

Gráfico 7 - Gráficos dot plot representativo obtido por citometria de fluxo para os marcadores de citoesqueleto CK-8 (A), CK-18 (B) e Desmina (C), em 
células do broto hepático de ratos Fischer 344 nos períodos 12,5; 14,5 e 16,5 dias. Adquiridas pelo programa CellQuestPro e analisado no programa WinMDI 2.9.

Gráfico 8 - Gráfico de barras representando os valores de média \pm DP para os reguladores de progressão do ciclo celular expressos em células do broto hepático nos diferentes dias de gestação obtidos por citometria de fluxo

Gráfico 9 - Gráficos dot plot representativo obtido por citometria de fluxo para os marcadores de ciclo celular P53 (A), P21 (B), P27 (C) e Ciclina D1 (D), em células do broto hepático de ratos Fischer 344 nos períodos 12,5; 14,5 e 16,5 dias. Adquiridas pelo programa Cell Quest Pro e analisado no programa WinMDI2.9.

Gráfico 10 - Gráfico de barras representando os valores de média \pm DP para os marcadores de vias de morte celular programada (apoptose) e necrose, expressos em células do broto hepático de ratos Fischer 344 nos diferentes dias de gestação obtidos por citometria de fluxo.

Gráfico 11 - Gráficos dot plot representativo obtido por citometria de fluxo para os marcadores de vias de morte celular Anexina/ PI (A), Caspase-3 (B), BAX (C), BAD (D), BCl-2 (E), em células do broto hepático de ratos Fischer 344 nos períodos 12,5; 14,5 e 16,5 dias. Adquiridas pelo programa CellQuestPro e analisado no programa WinMDI 2.9 . 92

Gráfico 12 - Gráfico de barras representando os valores de média \pm DP para os valores expressos do potencial elétrico da mitocôndria das células $\mathrm{CBH}$ nos diferentes períodos de gestação, em comparação ao hepatócito de rato normal........................................................ 94 
Gráfico 13 - Gráfico de barras representando as médias e desvio padrão das diferentes fases do ciclo celular das populações de células do broto hepático. Observa-se a maior proporção de células na fase de

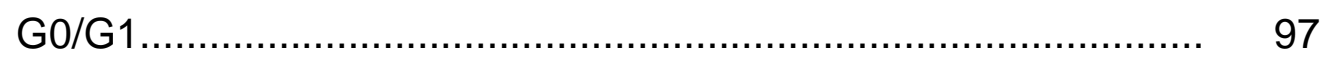

Gráfico 14 - Gráfico das frações das fases do ciclo celular das células do broto hepático CBH 12, 5 dias.......................................................... 98

Gráfico 15 - Gráfico das frações das fases do ciclo celular das células do broto hepático CBH 14, 5 dias........................................................ 98

Gráfico 16 - Gráfico das frações das fases do ciclo celular das células do broto hepático CBH16, 5 dias............................................................ 99

Gráfico 17 - Gráfico de barras representando os valores de média \pm DP para produção de radicais livres lipoperoxidados (LPO) de células $\mathrm{CBH}$ nos diferentes dias de gestação em comparação ao meio de cultura e do hepatócitos de rato normal....................................................... 101 


\section{LISTA DE TABELAS}

Tabela 1 - Valores de média de expressão TGO de células do broto hepático de diferentes períodos de cultura em comparação ao hepatócito normal

Tabela 2 - Valores de média de expressão TGP (U/L) da CBH nos diferentes períodos de gestação em comparação ao hepatócito normal

Tabela 3- Valores de média de expressão dos marcadores de células-tronco mesenquimais obtido por citometria de fluxo em $\mathrm{CBH}$ de diferentes períodos de gestação

Tabela 4 - Valores de média de expressão dos marcadores de citoesqueleto obtido por citometria de fluxo em $\mathrm{CBH}$ de diferentes períodos de gestação

Tabela 5 - Valores de média de expressão dos marcadores de ciclo celular obtidos por citometria de fluxo em $\mathrm{CBH}$ de diferentes períodos de gestação

Tabela 6- Valores de média de expressão dos marcadores de vias de morte celular programada em células obtidas por citometria de fluxo em $\mathrm{CBH}$ de diferentes períodos de gestação 90

Tabela 7 - Valores de média e desvio padrão do potencial elétrico mitocondrial em $\mathrm{CBH}$ nos diferentes períodos de gestação.

Tabela 8 - Valores de média e desvio padrão das diferentes fases do ciclo celular das populações de células do broto hepático de ratos Fischer 344, nos diferentes dias de gestação obtido por citometria de fluxo 
Tabela 9 - Valores de média \pm DP de expressão de peroxidação lipídica (LPO) das $\mathrm{CBH}$ nos diferentes períodos de gestação em comparação ao meio de cultura e ao hepatócito de rato normal........................................... 100 


\section{LISTA DE APÊNDICES}

Apêndice A - Análise estatística do broto hepático de ratos Fischer 344 em diferentes idades gestacionais 12,$5 ; 14,5$ e 16,5 dias, para TGO. 122

Apêndice B - Análise estatística do broto hepático de ratos Fischer 344 em diferentes idades gestacionais 12,$5 ; 14,5$ e 16,5 dias, para TGP.

Apêndice C - Análise estatística do broto hepático de ratos Fischer 344 em diferentes idades gestacionais $12,5,14,5$ e 16,5 dias, para 0 marcador de células mesenquimais CD90.

123

Apêndice D - Análise estatística do broto hepático de ratos Fischer 344 em diferentes idades gestacionais $12,5,14,5$ e 16,5 dias, para o marcador de células mesenquimais NANOG.

123

Apêndice E - Análise estatística do broto hepático de ratos Fischer 344 em diferentes idades gestacionais $12,5,14,5$ e 16,5 dias, para o marcador de células mesenquimais ОСТ $3 / 4$.

Apêndice F - Análise estatística do broto hepático de ratos Fischer 344 em diferentes idades gestacionais 12,5, 14,5 e 16,5 dias, para o marcador de células mesenquimais STRO-1.

Apêndice G - Análise estatística do broto hepático de ratos Fischer 344 em diferentes idades gestacionais $12,5,14,5$ e 16,5 dias, para o marcador de citoesqueleto CK-8

Apêndice H - Análise estatística do broto hepático de ratos Fischer 344 em diferentes idades gestacionais $12,5,14,5$ e 16,5 dias, para o marcador de citoesqueleto CK-18. 
Apêndice I - Análise estatística do broto hepático de ratos Fischer 344 em diferentes idades gestacionais $12,5,14,5$ e 16,5 dias, para o marcador de citoesqueleto DESMINA.

Apêndice $\mathrm{J}$ - Análise estatística do broto hepático de ratos Fischer 344 em diferentes idades gestacionais $12,5,14,5$ e 16,5 dias, para o marcador progressão do ciclo celular P53.

126

Apêndice K -Análise estatística do broto hepático de ratos Fischer 344 em diferentes idades gestacionais $12,5,14,5$ e 16,5 dias, para o marcador progressão do ciclo celular P21

Apêndice L - Análise estatística do broto hepático de ratos Fischer 344 em diferentes idades gestacionais $12,5,14,5$ e 16,5 dias, para o marcador progressão do ciclo celular P27 ............................................... 127

Apêndice M - Análise estatística do broto hepático de ratos Fischer 344 em diferentes idades gestacionais $12,5,14,5$ e 16,5 dias, para o marcador progressão do ciclo celular CICLINA D1 ................... 128

Apêndice N - Análise estatística do broto hepático de ratos Fischer 344 em diferentes idades gestacionais 12,5, 14,5 e 16,5 dias, para o marcador de vias de morte celular ANEXINA V

Apêndice $O$ - Análise estatística do broto hepático de ratos Fischer 344 em diferentes idades gestacionais 12,5, 14,5 e 16,5 dias, para o marcador de morte celular $\mathrm{PI}$ 129

Apêndice P - Análise estatística do broto hepático de ratos Fischer 344 em diferentes idades gestacionais $12,5,14,5$ e 16,5 dias, para o marcador de morte celular CASPASE 3. 
Apêndice Q - Análise estatística do broto hepático de ratos Fischer 344 em diferentes idades gestacionais $12,5,14,5$ e 16,5 dias, para 0 marcador de vias de morte celular BAX.................................... 130

Apêndice R - Análise estatística do broto hepático de ratos Fischer 344 em diferentes idades gestacionais $12,5,14,5$ e 16,5 dias, para o marcador de morte celular BAD............................................. 130

Apêndice $S$ - Análise estatística do broto hepático de ratos Fischer 344 em diferentes idades gestacionais 12,5, 14,5 e 16,5 dias, para o marcador de vias de morte celular BCL-2

Apêndice T - Análise estatística do broto hepático de ratos Fischer 344 em diferentes idades gestacionais 12,5, 14,5 e 16,5 dias, para o marcador de citoesqueleto CK-18 .......................................................... 132

Apêndice U - Análise estatística do broto hepático de ratos Fischer 344 em diferentes idades gestacionais 12,5, 14,5 e 16,5 dias, para o ciclo celular na fase G0/G1 ...................................................... 133

Apêndice V - Análise estatística do broto hepático de ratos Fischer 344 em diferentes idades gestacionais 12,5, 14,5 e 16,5 dias, para o ciclo celular na fase S................................................................ 133

Apêndice W - Análise estatística do broto hepático de ratos Fischer 344 em diferentes idades gestacionais 12,5, 14,5 e 16,5 dias, para o ciclo celular na fase $\mathrm{G} 2 / \mathrm{M}$. 134

Apêndice X - Análise estatística do broto hepático de ratos Fischer 344 em diferentes idades gestacionais 12,5, 14,5 e 16,5 dias, para o ciclo celular na fase DNA fragmentado. 
Apêndice $Y$ - Análise estatística do broto hepático de ratos Fischer 344 em diferentes idades gestacionais 12,5; 14,5 e 16,5 dias, para LPO 135

Apêndice Z - Curva padrão Bradford (proteínas total)..................................... 136 


\section{SUMÁRIO}

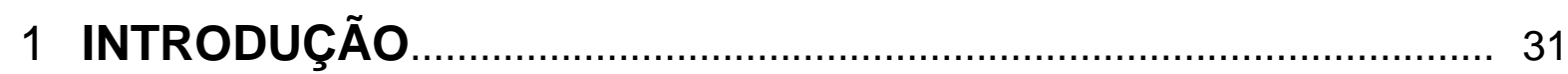

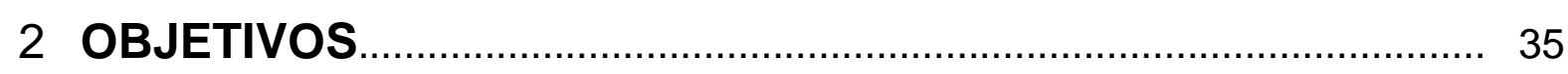

2.1 Objetivos gerais................................................................... 36

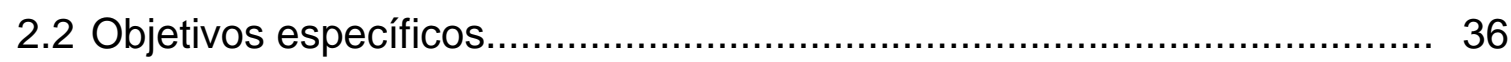

3 REVISÃO DE LITERATURA ................................................................... 37

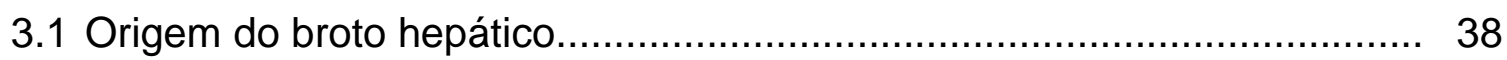

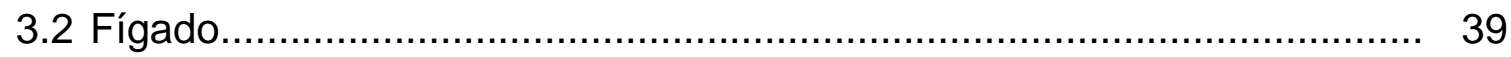

3.3 Desenvolvimento embrionário...................................................... 40

3.4 Hepatogênese ............................................................................... 41

3.5 Células-tronco e terapia celular............................................... 43

3.6 Cultivo celular............................................................................ 46

3.7 Análises Bioquímicas............................................................ 46

3.8 Citometria de fluxo e marcadores celulares........................................ 47

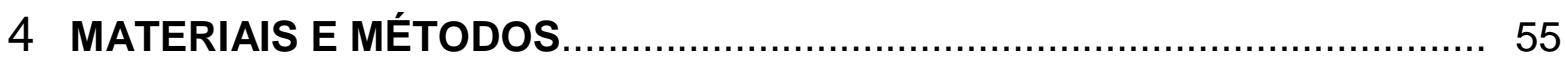

4.1 Obtenção de célula broto hepático.................................................. 56

4.1.1 Animais e amostras.............................................................. 56

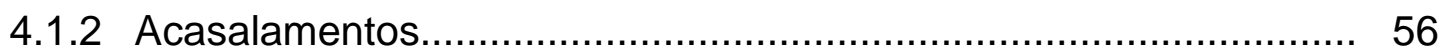

4.1.3 Colheita do material.......................................................... 57

4.1.4 Cultivo celular.............................................................. 58

4.1.5 Congelamento celular para banco de células-tronco.................... 59

4.2 Caracterização morfológica da cultura de células do broto hepático....... 59

4.2.1 Microscopia Eletrônica de Varredura ......................................... 60

4.3 Análise das Transaminases hepáticas................................................. 60

4.3.1 Quantificação de concentração de proteínas totais...................... 60

4.3.2 Transaminase glutâmico oxalacética hepática (TGO).................. 61

4.3.3 Transaminase glutâmico pirúvica hepática (TGP) .................... 62

4.4 Análises de marcadores por citometria de fluxo................................. 62 
4.4.1 Marcadores de células mesenquimais.......................................... 63

4.4.2 Marcadores de citoesqueleto.................................................. 63

4.4.3 Marcadores envolvidos na checagem e progressão do ciclo celular 64

4.4.4 Marcadores envolvidos na morte celular...................................... 65

4.4.5 Análise do potencial elétrico mitocondrial ................................... 65

4.4.6 Análise das fases do ciclo celular.............................................. 66

4.4.6.1 Incorporação do lodeto de Propídio (PI) e Leitura das Amostras.. 66

4.4.6.2 Interpretação dos Resultados................................................... 66

4.5 Determinação in vitro de produtos de radicais peroxidados dos lipídios

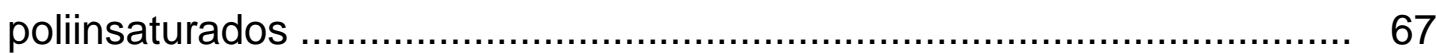

4.6 Análise estatística .................................................................. 68

5 RESULTADOS

5.1 Obtenção de célula do broto hepático ……………........................... 70

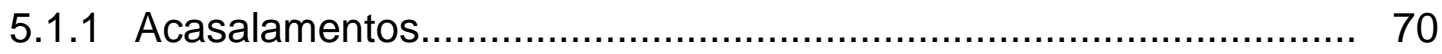

5.1.2 Isolamento e separação do broto hepático dos embriões e fetos de

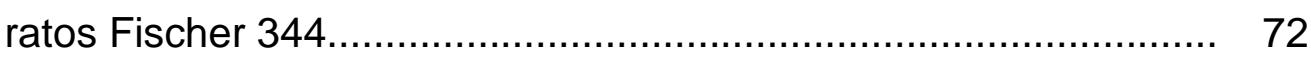

5.2 Caracterização dos aspectos morfológicos das células do broto hepático 74

5.2.1 Fotodocumentação do Cultivo Celular........................................... 74

5.2.2 Microscopia Eletrônica de Varredura............................................ 75

5.3 Análises Bioquímicas....................................................................... 78

5.3.1 Transaminase Glutâmico Oxalacética (TGO)............................ 78

5.3.2 Transaminase Glutâmico Pirúvica (TGP).................................... 79

5.4 Análises dos marcadores por citometria de fluxo.................................. 80

5.4.1 Marcadores de Células Mesenquimais - células-tronco.................. 81

5.4.2 Marcadores de citoesqueleto................................................... 84

5.4.3 Reguladores do ciclo celular..................................................... 87

5.4.4 Marcadores de vias de morte celular......................................... 90

5.4.5 Análise do Potencial Elétrico Mitocondrial..................................... 93

5.4.6 Análise das Fases do Ciclo Celular............................................. 95

5.5 Determinação in vitro de produtos da peroxidação lipídica por quantificação de TBARS (LPO)... 
6 DISCUSSÃO.

102

7 CONCLUSÃO. 109 REFERÊNCIAS 112 APÊNDICES 


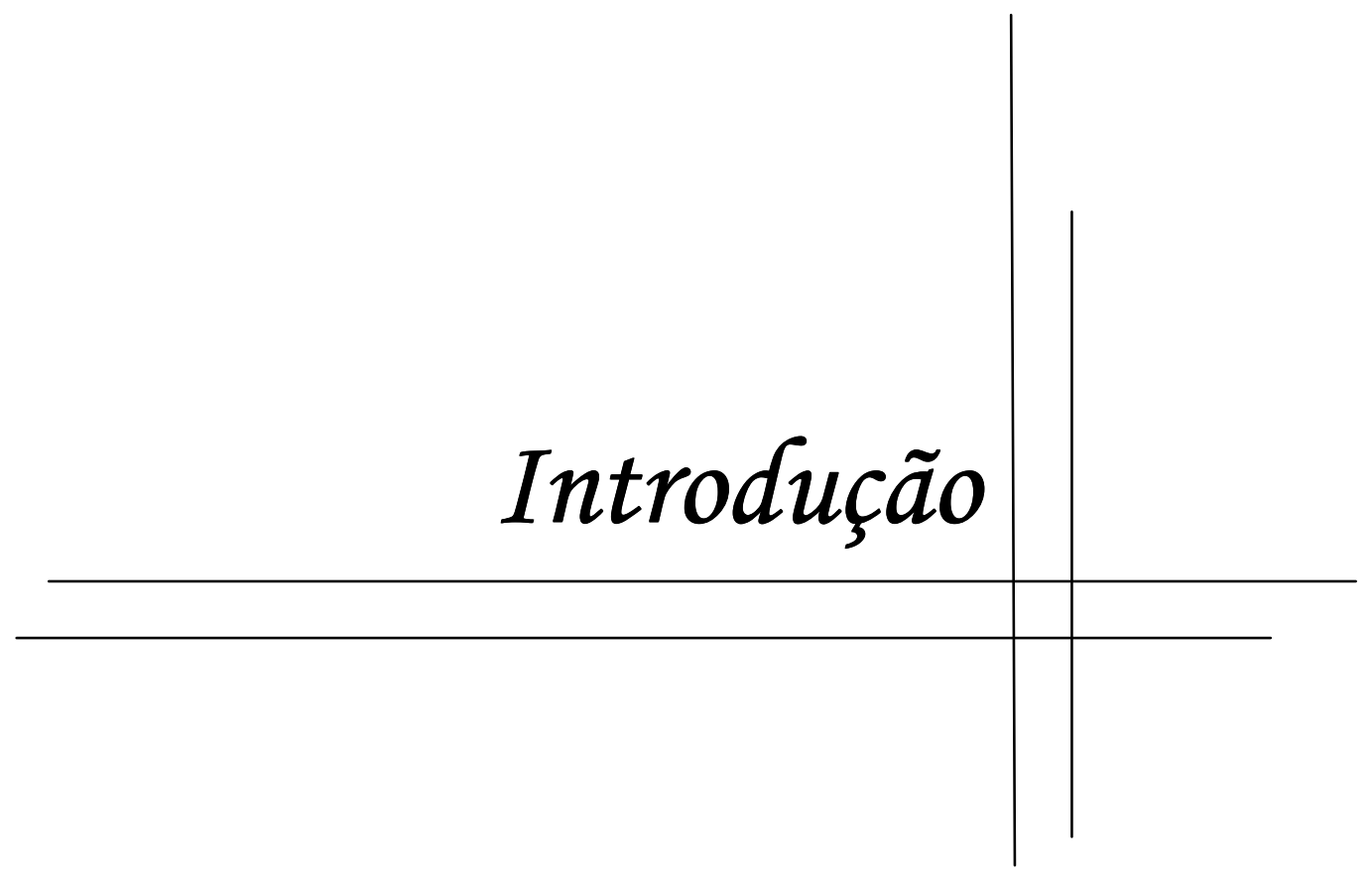




\section{INTRODUÇÃO}

Embriologicamente o broto hepático (divertículo hepático), surge na parte caudal do intestino anterior e cresce no mesoderma do septo transverso. Esse mesoderma forma o tecido conjuntivo do fígado, o tendão central do diafragma e o mesentério ventral do intestino, que o próprio fígado separa em duas partes (MOORE et al., 2001)

As células no corpo mostram uma notável variedade na capacidade de se dividir e crescer. Algumas células atingem um estado diferenciado e maduro e, normalmente, não se dividem. Tais células são mencionadas como células pósmitóticas. Outras células, chamadas de células-tronco, apresentam divisões contínuas por toda a vida. Muitas outras células são intermediárias entre esses dois extremos e permanecem quiescentes na maior parte do tempo, porém, podem ser estimuladas a se dividir através de sinais apropriados. Um exemplo são os hepatócitos. Se o fígado for lesado, a divisão celular pode ser deflagrada para compensar as células perdidas (KIERSZENBAUM, 2008).

As células-tronco possuem três propriedades: auto-renovarão, proliferação e diferenciação. Elas têm o potencial para gerar um grande número de células maduras continuamente durante a vida (KIERSZENBAUM, 2008). As células-tronco podem ser classificadas em três categorias de acordo com o período de isolamento durante a ontogênese: embrionária, fetal e adulta. $O$ termo refere-se a células com habilidade em gerar células filhas com características similares às da célula mãe, bem como diferenciar-se em células especializadas (GACE, 2000).

A primeira população de células-tronco foi identificada na medula óssea de camundongos adultos por McCulloch e Till em 1960. Este trabalho pioneiro identificou as características de células-tronco nas células-tronco hematopoiéticas da medula óssea (BECKER; MCCULLOCH; TILL,1963). Atualmente há um grande número de populações de células-tronco multipotentes isoladas e caracterizadas a partir de tecidos adultos (CAPLAN, 1991; FRIEDENSTEIN; PIATETZKY-SHAPIRO; PETRAKOVA, 1966;; PITTENGER et al.,1999). 
As células-tronco embrionárias são uma classe especial de células-tronco derivadas de embriões mamíferos no estágio de blastocisto. Neste estágio, células da massa celular interna, que vão dar origem a todos os tecidos do indivíduo adulto, ainda não se diferenciaram e podem ser colocadas em cultura de forma a estabelecer uma linhagem de células-tronco embrionárias. A capacidade dessas células de se multiplicar em cultura sem perder a pluripotência, assim como a possibilidade de induzir sua diferenciação em tipos celulares específicos, tornou as células-tronco embrionárias uma poderosa ferramenta de pesquisa e uma promissora fonte de tecidos para transplante (ZAGO; COVAS, 2006).

As células-tronco fetais são uma alternativa de células-tronco recém descoberta que podem ser isoladas a partir do próprio feto e de estruturas extras fetais de suporte. O principal tipo de células-tronco isolada dos tecidos fetais é a células-tronco mesenquimal que possui um potencial de expansão superior as células-tronco derivadas de tecidos adultos e é menos imunogênica, pois não expressa antígeno tipo II de superfície de leucócito humano (HLA) (MIAO et al.,2006).

As doenças, envolvendo órgãos endodermicamente derivados, particularmente pulmões, fígado e pâncreas, incluindo fibrose cística, hepatite crônica e diabetes respectivamente, afetam milhares de pessoas no mundo. Uma via de tratamento para esses pacientes é estimular a regeneração do tecido atingido in vivo ou gerar tecido de substituição in vitro. Experimentos com células-tronco têm sido realizados para tratar doenças em órgãos mesodermicamente derivados (sistema hematopoiético), e tecidos ectodermicamente derivados (pele) têm sido cultivados para o tratamento de vítimas queimadas. O sucesso destes tratamentos gera ótimas perspectivas para a terapia celular em doenças de órgãos oriundos da endoderme (SPENCE; WELLS, 2007).

A camada endodérmica embrionária dá origem ao epitélio do sistema digestório e do trato respiratório, que por sua vez compreende os órgãos: tireóide, pulmões, fígado, vesícula biliar e pâncreas. Particularmente, no fígado, ainda que sejam atribuídas propriedades regenerativas, muitas das lesões são tão prejudiciais que este mecanismo de reparação é insuficiente, tornando a transplantação a única opção (MURACA ; GERUNDA; NERI , 2002; SELDEN; HODGSON, 2004). 
O uso de hepatócitos primários, derivados de um número reduzido de células de fígado adulto para cultivo celular, poderia ser utilizado como uma solução para o número limitado de doadores humanos. Contudo, observa-se que estas células não possuem grande habilidade de proliferação in vitro. Este mesmo problema não é verificado em células-tronco embrionárias, as quais mantêm seu potencial de diferenciação para diversos tipos celulares e consequentemente as torna fonte importante para a terapia celular (PARK; LEE, 2005). Outra fonte importante são as células de linhagens hepáticas fetais pré-estabelecidas que, de acordo com Kiyota; Matsushinta e Ueoka, (2007), promovem maior índice de diferenciação.

Os avanços na compreensão dos mecanismos de controle, envolvidos na formação e desenvolvimento hepático, vêm gerando diversas implicações em: diagnósticos de enfermidades hepáticas observadas em indivíduos jovens e adultos; diferenciação in vitro de células-tronco adultas e embrionárias em tecido hepático; e tratamento de lesões hepáticas agudas e crônicas, inclusive com uso de terapia a partir de células-tronco (MCLIN; ZORN, 2006). Diversos autores têm evidenciado que muitas destas vias moleculares, envolvidas no crescimento e desenvolvimento do fígado, vêm sendo observadas no desencadeamento e evolução de doenças hepáticas, bem como em processos regenerativos e de neo formações tumorais (BEHRENS et al. 2002; LJUBIMOVA et al.,1997; PARK et al., 2001; SAKATA et al., 1996; SCHWABE et al. 2003; STURM et al., 2004TAKAYASU et al., 2001; WANG et al. 2002; YANG et al., 2003; WANG et al. 2003).

Avaliar o potencial e o controle da resposta proliferativa de células do broto hepático em diferentes idades gestacionais, durante a maturação dos hepatócitos em cultura pode ser uma fonte importante para a terapia celular em indivíduos com doenças hepáticas ou nos defeitos genéticos na formação do parênquima hepático e biliar. 


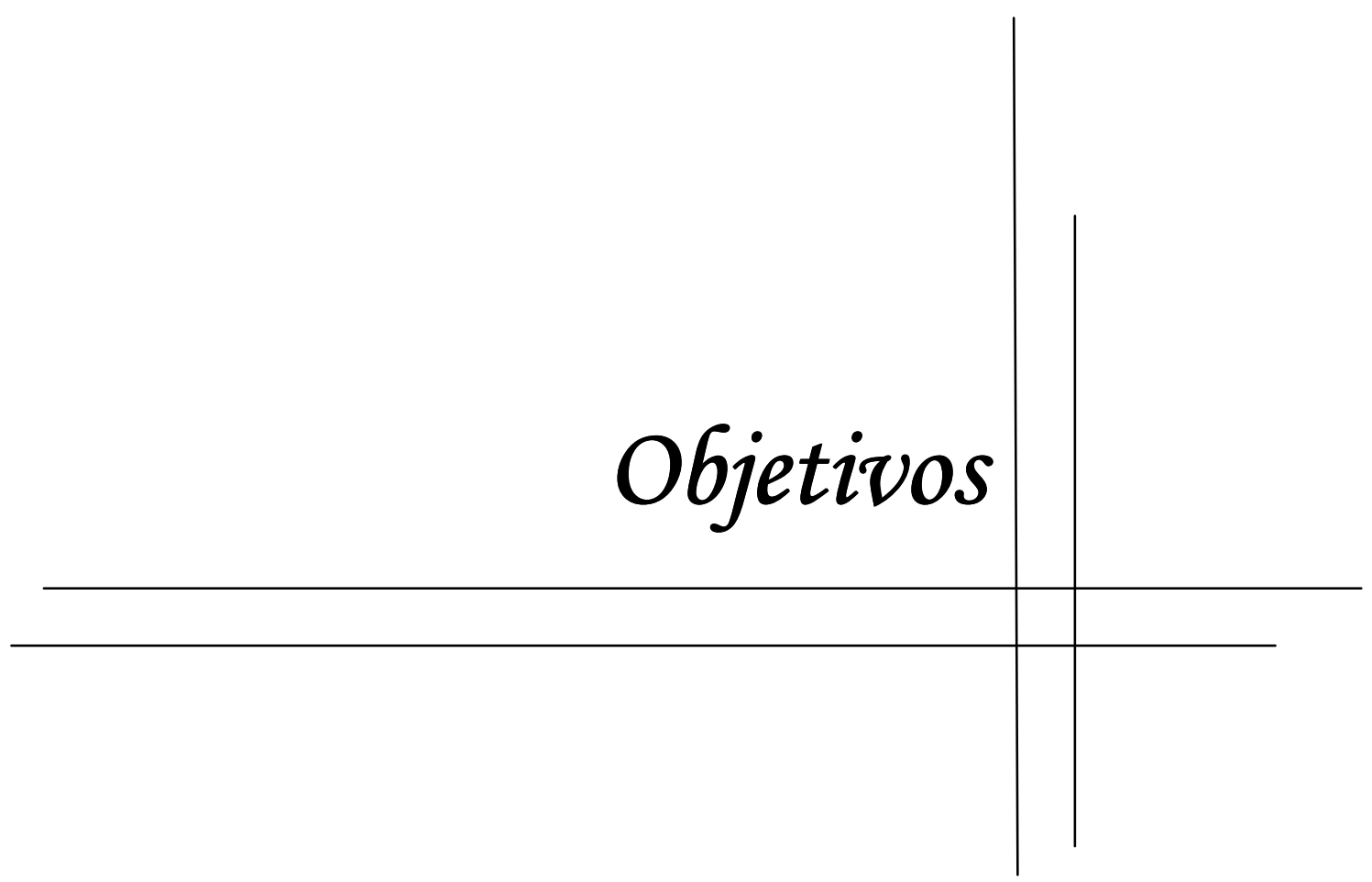




\section{OBJETIVOS}

As células do broto hepático de ratos Fischer 344 podem ser consideradas uma célula-tronco como uma fonte utilizada em terapia celular?

\subsection{OBJETIVOS GERAIS}

- Avaliar o potencial e o controle da resposta proliferativa de células do broto hepático, durante a sua maturação em cultura.

\subsection{OBJETIVOS ESPECÍFICOS}

- Obtenção do broto hepático de ratos Fisher 344 nas diferentes idades gestacionais;

- Cultivo, expansão e caracterização dos marcadores das células do broto hepático. 


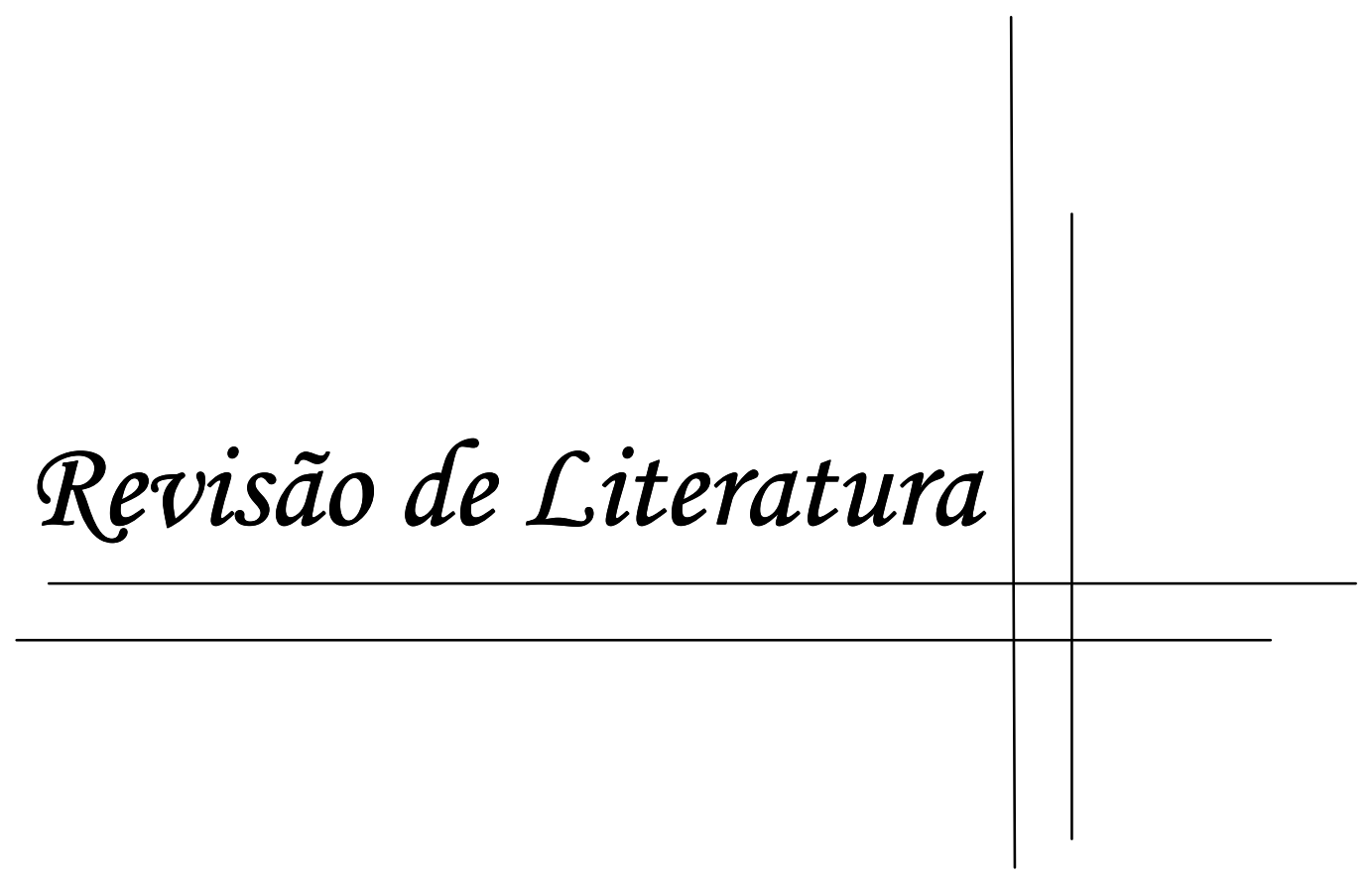




\section{REVISÃO DE LITERATURA}

Os avanços na compreensão dos mecanismos de controle envolvidos na formação e desenvolvimento hepático vêm gerando diversas implicações em diagnósticos de enfermidades hepáticas observadas em indivíduos jovens e adultos. Diferenciação in vitro de células-tronco adultas e embrionárias em tecido hepático e tratamento de lesões hepáticas agudas e crônicas, uso de terapia a partir de célulatronco (MCLINEZORN, 2005). A revisão de literatura nos dará subsídios para uma melhor compreensão das células de linhagens hepáticas embrionárias e fetais em ratos Fischer 344.

\subsection{Origem do broto hepático}

O broto hepático (divertículo hepático) surge na parte caudal do intestino anterior e cresce no mesoderma do septo transverso. Esse mesoderma forma o tecido conjuntivo do fígado, o tendão central do diafragma e o mesentério ventral do intestino, que o próprio fígado separa em duas partes: omento menor, que se estende do fígado ao esôfago inferior, estômago e duodeno superior, e o ligamento falciforme, que se estende do fígado até a parede ventral do corpo, e que abriga a veia umbilical em sua borda livre (caudal). Essa associação próxima do fígado ao septo transverso esta evidenciada pelo fato de o tendão central do diafragma permanecer ligado diretamente ao fígado na região chamada não revestida do fígado (o restante do fígado é coberto pelo peritônio visceral). A porção proximal do broto hepático forma o ducto biliar e também dá origem a outro broto do qual se formam o ducto cístico e a vesícula biliar. Durante a vida fetal (da 10 semana ao 7 mês), o fígado atua como o principal órgão hematopoiético até que sejam estabelecidos os recursos da medula óssea (BANKS, 1994).

Curiosamente, o intestino anterior, em toda a sua extensão, é capaz de formar tecido hepático, mas esse potencial é inibido por fatores secretados que provêm de tecidos vizinhos, inclusive do notocórdio e do mesoderma não cardíaco. Entretanto, na região do intestino anterior formadora do fígado a ação inibitória desses fatores é contrabalançada pelos FGFs secretados pelo mesoderma cardíaco 
adjacente (dois negativos formam um positivo). O efeito final é o aumento da expressão dos fatores de transcrição nuclear HNF3 e HNF4 pelo hepatócito, que induz as células do endoderma para se diferenciarem em tecido hepático (SADLER, 2007).

\subsection{Fígado}

O fígado é o segundo maior órgão do corpo e a maior glândula. Está situado na cavidade abdominal abaixo do diafragma. O fígado é o órgão no qual os nutrientes absorvidos no trato digestivo são processados e armazenados para utilização por outros órgãos. É, portanto, uma interface entre o sistema digestivo e o sangue. Grande parte do sangue que vai para o fígado chega pela veia porta (70$80 \%$ ); uma menor porcentagem é suprida pela artéria hepática. Todos os nutrientes absorvidos pelo intestino chegam ao fígado pela veia porta, exceto os lipídios complexos (quilomícrons), que chegam ao fígado pela artéria hepática. A posição do fígado no sistema circulatório é ideal para captar, transformar e acumular metabólitos e para a neutralização e eliminação de substâncias tóxicas. A eliminação ocorre na bile, uma secreção exócrina do fígado, importante para a digestão de lipídios. O fígado também exerce função muito importante na produção de proteínas plasmáticas, como a albumina e outras proteínas carregadoras (JUNQUEIRA; CARNEIRO, 2008).

O fígado é revestido por uma cápsula delgada de tecido conjuntivo (cápsula de Glisson), que se torna mais espessa no hilo, por onde a veia porta e a artéria hepática penetram no fígado e por onde saem os ductos hepáticos direito e esquerdo e os linfáticos. Estes vasos e ductos são circundados por tecido conjuntivo ao longo de toda a sua extensão, até o término (ou origem) nos espaços porta entre os lóbulos hepáticos. Neste ponto, forma-se uma delicada rede de fibras reticulares que suporta os hepatócitos (células do fígado) e células endoteliais dos capilares sinusóides (JUNQUEIRA; CARNEIRO, 2008).

O componente estrutural básico do fígado é a célula hepática, ou hepatócito. Estas células epiteliais são agrupadas em placas interconectadas. Em cortes histológicos, unidades estruturais denominadas lóbulos hepáticos. O lóbulo hepático 
é formado por uma massa poligonal de tecido cujo tamanho oscila. Em algumas regiões da periferia dos lóbulos existe tecido conjuntivo contendo ductos biliares, vasos linfáticos, nervos e vasos sanguíneos. Estas regiões, os espaços porta, estão presentes nos cantos dos lóbulos (JUNQUEIRA; CARNEIRO, 2008).

\subsection{Desenvolvimento embrionário}

O desenvolvimento embrionário dos vertebrados tem sido estudado por muito tempo, e durante as últimas duas décadas um enorme progresso foi obtido no estudo da definição das linhagens celulares, do potencial de desenvolvimento celular em embriões jovens e na compreensão dos mecanismos moleculares que regulam a modelagem e diferenciação celular. $O$ desenvolvimento embrionário no camundongo leva de 18 a 20 dias, já o do rato gira em torno 21 a 22 dias (CUBAS et al., 2007).

Os dois primeiros folhetos embrionários já se encontram diferenciados no blastocisto no dia 3,5 (em camundongo) após a fecundação $(E 3,5)$, sendo que a implantação ocorre um dia mais tarde (KAUFMAN; BARD, 1999; ROSSANT; TAM, 2002). O desenvolvimento prossegue rapidamente após a implantação, com a insinuação do embrião à forma cilíndrica. Subsequentemente, a formação dos três folhetos embrionários (ectoderme, mesoderme e endoderme), no começo da gastrulação (E6,5 em camundongo) ocorre mudanças morfológicas dramáticas. Durante a gastrulação, a disposição do corpo com seus eixos principais são estabelecidos, seguindo-se a organogênese, em torno do dia 10,5 (em camundongo). Nesse momento, o desenvolvimento embrionário da maioria dos órgãos primordiais já está definido (ROSSANT; TAM, 2002).

A endoderme embriônica é uma camada simples de epitélio pavimentado, formada por volta do dia 7,5 (em camundongo), cuja função compreende a formação do trato digestório e respiratório do embrião. Após 24 horas deste processo, iniciamse movimentos morfogenéticos na região anterior da endoderme, que resultam na formação do intestino primitivo anterior cujo epitélio, nesse estágio, é cubóide. 0 intestino anterior dá origem à tireóide, pulmões, fígado, vesícula biliar, estômago e 
pâncreas. Dentre as vias que implicam na formação do intestino anterior, estão FGF, Wnt, ácido retinóico e hedgehog (GRAPIN-BOTTON, 2005).

Embriões devem ser classificados de acordo com a idade, cumprimento, peso ou número de somitos, no caso de espécies jovens. O desenvolvimento do camundongo é similar ao do rato, com algumas diferenças, nos ratos o desenvolvimento é mais avançado do que em camundongos em alguns estágios. Geralmente quando o período gestacional é curto, o desenvolvimento embrionário é rápido e o número de filhotes em uma ninhada é grande. Neste caso, o ritmo de desenvolvimento difere sensivelmente nas fases iniciais, mas nos estágios posteriores as diferenças tendem a ser menores (MONIE, 1976).

O desenvolvimento embrionário dos ratos é similar ao dos outros vertebrados, a gastrulação inicia-se no oitavo dia de gestação $(E 8,5)$. A formação dos somitos começa no final de E9,5 e durante E10,5, quando o intestino anterior e posterior tornam-se visíveis e o processo de desenvolvimento hepático se inicia, o que se dá pela conectividade da endoderme do intestino anterior com o desenvolvimento do coração. Proteínas morfogenéticas do osso (BMPs) e fatores de crescimento de fibroblastos (FGFs) sinalizam o início do septo transverso e o desenvolvimento do coração respectivamente, e fatores de transcrição ativam genes hepáticos específicos que regulam a hepatogênese (GOTTINGEN, 2006)

\subsection{Hepatogênese}

O processo de hepatogênese é composto por múltiplos estágios de desenvolvimento. Durante o desenvolvimento embrionário, a indução da destinação hepática depende de interações recíprocas entre o endoderma ventral do intestino anterior e o tecido mesenquimal adjacente (ZARET, 2002). Aproximadamente no E8 (em camundongo) a parede ventral do endoderma do intestino anterior inicia seu desenvolvimento para uma destinação hepática em resposta às ações indutivas de fatores de crescimento, incluindo FGF liberado pelo mesoderma cardíaco adjacente e pelas BMPs advindas do mesênquima do septo transverso (BAHARVAND et al., 2006; DUNCAN, 2003). 
As células da endoderme do intestino anterior começam a proliferar e diferenciar em hepatoblasto, levando à formação do broto hepático em E9 (em camundongos). Uma vez que o broto hepático é gerado e os hepatoblastos do intestino anterior migram formando cordões em direção ao septo mesenquimal transverso, as células dentro do ambiente hepático embriônico se organizam para uma segunda diferenciação celular gerando uma arquitetura hepática complexa (ZHAO; DUNCAN, 2005).

A diferenciação do hepatoblasto em hepatócitos e em células do epitélio biliar (cholangiócitos) começa em torno do E13,5 (em camundongos). Esta diferenciação final, na linhagem celular hepática em camundongos, ocorre até por volta do E17, quando: a maior parte das células adota uma morfologia cuboidal característica; observam-se canalículos formados no tecido; e detectam-se enzimas e proteínas necessárias para o exercício da função hepática nas células que formam o fígado do embrião (MCLIN; ZORN, 2006).

O fígado embrionário representa o maior sítio de hematopoiese durante 0 desenvolvimento embrionário. Nos ratos, o broto hepático começa a se desenvolver com 10 dias de gestação $(E 10,5)$, juntamente com a maturação da medula óssea e baço, as células hematopoiéticas saem do fígado para suas destinações finais, enquanto o fígado inicia a organização de sua estrutura e desenvolve numerosas funções metabólicas tornando-se maduro ( GOTTINGEN, 2006).

Dentre os fatores envolvidos na regulação do desenvolvimento hepático encontram-se HNF1a e $\beta$, HNF3 $\alpha$, e $\gamma$, HNF4a, HNF6 (COSTA et al., 2003; DUNCAN, 2000) e Cited2 (QU; LAM; DOUGHMAN, 2007). Trabalhos sugerem que HNF4a atua como regulador central da hepatogênese, através da ativação da cascata de fatores de transcrição que geram o perfil final da expressão gênica do hepatócito maduro (WATT et al, 2003). Para Parviz et al. (2003) e Rhee et al. (2003) o HNF4a é o maior regulador da expressão gênica hepática, atuando tanto no desenvolvimento, como na diferenciação celular em linhagem hepática. O Cited, conforme descrito por Withington et al. (2002), também desempenha função essencial no desenvolvimento embriônico hepático em camundongo. Ela é altamente expressa por fígados fetais do E12,5 até E16,5 (QU; LAM; DOUGHMAN, 2007). Na embriogênese do camundongo, a expressão do Cited2 também é evidenciada nos mesênquima do septo transverso, a região a qual dá origem ao 
fígado maturo (DUNCAWOODIE; RODRIGUEZ; BEDDINGTON, 1998) e possui atuação como co-ativador do HNF4a. Outro fator de crescimento, o HGF, também está envolvido na hepatogênese, atuando na mantença dos hepatócitos a partir da metade da hepatogênese (BAHARVAND et al., 2006).

As células não diferenciadas do epitélio hepático de ratos, conforme observações de Bisgaard et al. (1994) expressam CK14 e vimentina. Enquanto que uma vez diferenciadas em hepatócitos expressam albumina, AFP, CK18 e glicogênio e as células do ducto biliar expressam glutamil transpeptidase (GGT) e CK19. No entanto, o fígado embrionário não possui muitas das funções hepáticas de um vertebrado adulto, que o torna centro metabólico do organismo, sendo estas adquiridas durante os estágios peri e pós-natal (BADVE et al., 2000).

A separação de células hepáticas progenitoras em fetos humanos entre 13-20 semanas foi obtida por Nyamath et al. (2007) por meio de separação magnética, isolando as células CD34+, e eliminando as CD45+ (linhagens linfóides e mielóides), aumentando assim em quatro vezes a positividade para AFP (marcador para hepatócitos fetais). Entretanto, apesar do sucesso, apenas 4,1 a 5,5\% das células apresentaram-se positivas para CD34 (marcador para células hepáticas progenitoras).

A obtenção de células do ducto biliar através da diferenciação de células endodermais hepáticas foi descrito por Shiojiri e Koike (1997) em um método de cocultivo dessas células com células mesenquimais heterólogas.

\subsection{Células-tronco e terapia celular}

Apesar da grande diversidade de células que podem ser reconhecidas em tecidos adultos, todas derivam de uma única célula ovo, após a fecundação de um óvulo por um espermatozóide. Essa única célula tem a propriedade de formar todos os tecidos do indivíduo adulto. Inicialmente, essa célula totipotente divide-se formando células idênticas, mas, muito precocemente na formação do embrião, os diferentes grupos celulares vão adquirindo características especializadas e, ao 
mesmo tempo, vão restringindo sua capacidade de diferenciação (ZAGO; COVAS, 2006).

No entanto, na maioria dos tecidos adultos existem reservas de células com capacidade de multiplicar-se, diferenciando-se naquele tecido a que pertencem e ao mesmo tempo mantendo esta própria reserva de células indiferenciadas. Essas células-tronco tecidos específicas são as responsáveis pela manutenção da integridade dos tecidos adultos, pelo reparo de tecidos lesados e pela remodelação dos tecidos e órgãos. Essas células progenitoras capazes de diferenciar-se em tecidos adultos especializados são denominadas células-tronco (ZAGO; COVAS, 2006).

Células-tronco diferem de outras células do organismo por apresentarem três características: a) são células indiferenciadas e não especializadas; b) são capazes de se multiplicar por longos períodos mantendo-se indiferenciadas, de forma que um pequeno número pode originar uma grande população de células semelhantes; c) são capazes de se diferenciar em células especializadas de um tecido particular. Em essência, as células-tronco são capazes de fazer "divisões assimétricas", ou seja, podem originar células que permaneçam indiferenciadas, repondo o pool de célulastronco, ou alternativamente podem se diferenciar em células especializadas (ZAGO; COVAS, 2006).

São células capazes de dar origem aos mais de 250 tipos diferentes de tecidos do adulto. São obtidas a partir do embrião em sua fase precoce de desenvolvimento e cultivadas in vitro. Incluem células derivadas do embrião, do feto ou de um tipo de célula híbrida em um processo chamado de transferência de núcleo somático (ZAGO; COVAS, 2006).

Quando o óvulo (contendo 23 cromossomos de origem materna ou metade do material genético nuclear de uma célula do corpo) é fecundado pelo espermatozóide (contendo 23 cromossomos de origem paterna), forma-se uma célula cujo núcleo contém 23 pares de cromossomos. Essa célula sofre repetidas divisões formando um "embrião" que, se conseguir implantar-se no útero, poderá desenvolver-se até a fase final de um feto e finalmente um adulto. Na fase inicial deste processo (4 ou 5 dia), o embrião (neste momento chamado de blastocisto) contém uma camada externa e uma massa celular interna. As células da massa interna vão dar origem ao feto e a parte dos tecidos extrafetais (âmnio e alantóide), ao passo que a camada 
externa de células (trofoectoderma) vai originar alguns tecidos restritos da placenta. Essas células da massa celular interna podem ser retiradas e cultivadas, dando origem a linhagens de células-tronco embrionárias, que têm capacidade de diferenciar-se nos diversos tecidos do adulto. (ZAGO; COVAS, 2006).

O número limitado de doadores de fígado para transplantes e a ausência de proliferação em culturas de hepatócitos, são os maiores fatores limitantes para as terapias que envolvam transplante hepático e hepatocitário, respectivamente. Essas características invibializam a utilização desses tratamentos em grande escala. Em contrapartida, progenitores hepáticos são altamente expansíveis in vitro in vivo. Essas células são capazes de extensiva proliferação e subsequente diferenciação em células do ducto biliar e hepatócitos (MALHI et al., 2002). Sendo assim, fígados fetais e embriônicos oferecem uma importante fonte de progenitores hepáticos para aplicações clínicas.

É sabido que durante a gestação (5 semanas em humanos) o processo de hematopoese migra temporariamente do saco vitelino para o fígado fetal (MIGLIACCIO et al., 1986), sendo o principal sítio de hematopoese no feto até o desenvolvimento da medula óssea. Diante desse fato, fica evidente a importância do estudo do fígado embrionário, não só para a Terapia Celular de doenças de órgãos oriundos do endoderma, mas, também advindas de tecidos hematopoiéticos.

Estudos utilizando hepatócitos primários suínos têm sido realizados visando o transplante para fígados de pacientes com falência hepática fulminante (WATANABE et al., 1997). Entretanto, a possibilidade de zoonoses e o uso de células xenogênicas para terapia humana têm limitações práticas. Outro obstáculo, é que hepatócitos primários, derivados de fígado adulto, não têm a habilidade de proliferar in vitro (PARK; LEE, 2005). Contudo, células-tronco embrionárias proliferam indefinidamente in vitro, mantendo seu potencial de diferenciação para quase todos os tipo celulares, sendo essencial o estabelecimento de métodos para proliferação de células-tronco hepáticas como uma fonte bipotencial para diferenciação de hepatócitos e células do ducto biliar in vitro (THOMSON et al., 1998). Essas linhagens além de promover possíveis tratamentos para doenças hepáticas, também têm importância nas pesquisas in vitro na elaboração de novos medicamentos, visto que o fígado é o principal órgão de desintoxicação do corpo (POUTON; HAYNES, 2005). 


\subsection{Cultivo celular}

A manutenção de células humanas, animais ou vegetais vivas fora do organismo (in vitro), é conhecida como cultura de células. Fornecida as condições apropriadas, as maiores partes destas células podem viver, multiplicar-se e até expressar propriedades particulares em uma placa ou garrafa de cultura (FRESHNEY, 1995).

De acordo com Banks (1992) a cultura celular é um método de observação direta das células vivas. Os antibióticos tornaram este método uma simples técnica rotineira. As técnicas de cultura permitem a observação, manipulação e testes contínuos das células semeadas sem qualquer risco ao doador. A diferenciação celular, as transformações celulares, a citogenética, o metabolismo celular, as interações intercelulares, as relações entre o parasita e os hospedeiros biológicos foram estudados por esta técnica.

A cultura celular vem sendo utilizada como sucesso em diferentes áreas como: obtenção de vacinas mais eficientes, métodos diagnósticos, reprodução humana, preservação de espécies animais ameaçadas de extinção, conhecimento de processos infecciosos e da biologia da célula tumoral, terapia gênica direcionando genes normais para substituir genes defeituosos em células tumorais, clonagem de embriões, entre outros (FRESHNEY, 1995).

\subsection{Análises Bioquímicas}

As transaminases ou aminotransferases, são enzimas presentes dentro das células do nosso organismo, sendo responsáveis pela metabolização das proteínas. As duas principais aminotransferases são a AST (aspartato aminotransferase) e ALT (alaninaaminotransferase). Estas enzimas estão presentes em várias células do nosso corpo e apresentam-se em grande quantidade no hepatócitos (células do fígado). O fígado é o órgão responsável pela metabolização de todas as substâncias presentes no sangue. A AST (TGO) está presente também nas células dos músculos e do coração, enquanto que a ALT (TGP) é encontrada quase que 
somente dentro das células do fígado. A ALT é, portanto, muito mais específica para o fígado que a AST. Toda vez que uma célula que contenha AST ou ALT sofre uma lesão, essas enzimas "vazam" para o sangue, aumentando a sua concentração sanguínea. Portanto, é fácil entender porque doenças do fígado, que causam lesão dos hepatócitos, cursam com níveis sanguíneos elevados de AST (TGO) e ALT (TGP) (VASCONCELOS; ALMEIADA; BACHUR, 2007).

\subsection{Citometria de fluxo e marcadores celulares}

A Citometria de fluxo é uma técnica utilizada para contar, examinar e classificar partículas microscópicas suspensas em meio líquido em fluxo. Permite a análise de vários parâmetros simultaneamente, sendo conhecida também por citometria de fluxo multiparamétrica. Através de um aparelho de detecção ópticoeletrônico são possíveis análises de características físicas e/ou químicas de uma simples célula (SAELENS et al, 2004).

O desenvolvimento tecnológico nas últimas décadas está direcionado para a elucidação dos mecanismos básicos que regulam a morte celular por apoptose, vias de sinalização de segundos mensageiros e nos eventos associados dos mediadores farmacologicamente ativos no controle da morte celular. O processo de morte celular possui um papel essencial na manutenção da homeostase tecidual incluindo o câncer, no controle do processo de proliferação (SAELENS et al, 2004).

A via de morte celular mitocondrial promove eventos apoptóticos mediado por vias de morte intrínseca (mitocondrial) e extrínseca (receptores de morte - família dos receptores do TNF). A morte celular intrínseca atua com a presença de membros pró-apoptóticos da família Bcl-2, mais precisamente, elementos da subfamília BH3 estas proteínas, que incluem a Bid, Bim. A interação entre proteínas das subfamílias BH3 e Bax leva à oligomerização dos elementos do último grupo, seguido de inserção na membrana externa da mitocôndria. Estas moléculas passam, então, a constituir canais de saída de proteínas intermembranares desde a mitocôndria até ao citoplasma, incluindo o citocromo c e o fator indutor da apoptose. O citocromo c, liberado, ativa uma proteína citoplasmática designada de Apaf-1, a 
qual recruta e ativa a pró-caspase-9, constituindo um complexo proteico denominado de apoptossoma. A caspase- 9 , na sua função de "caspase iniciadora", irá requerer e ativar a caspase-3, "executora", a qual degradará proteínas importantes para a viabilidade celular (HOWARD; PELC, 1953).

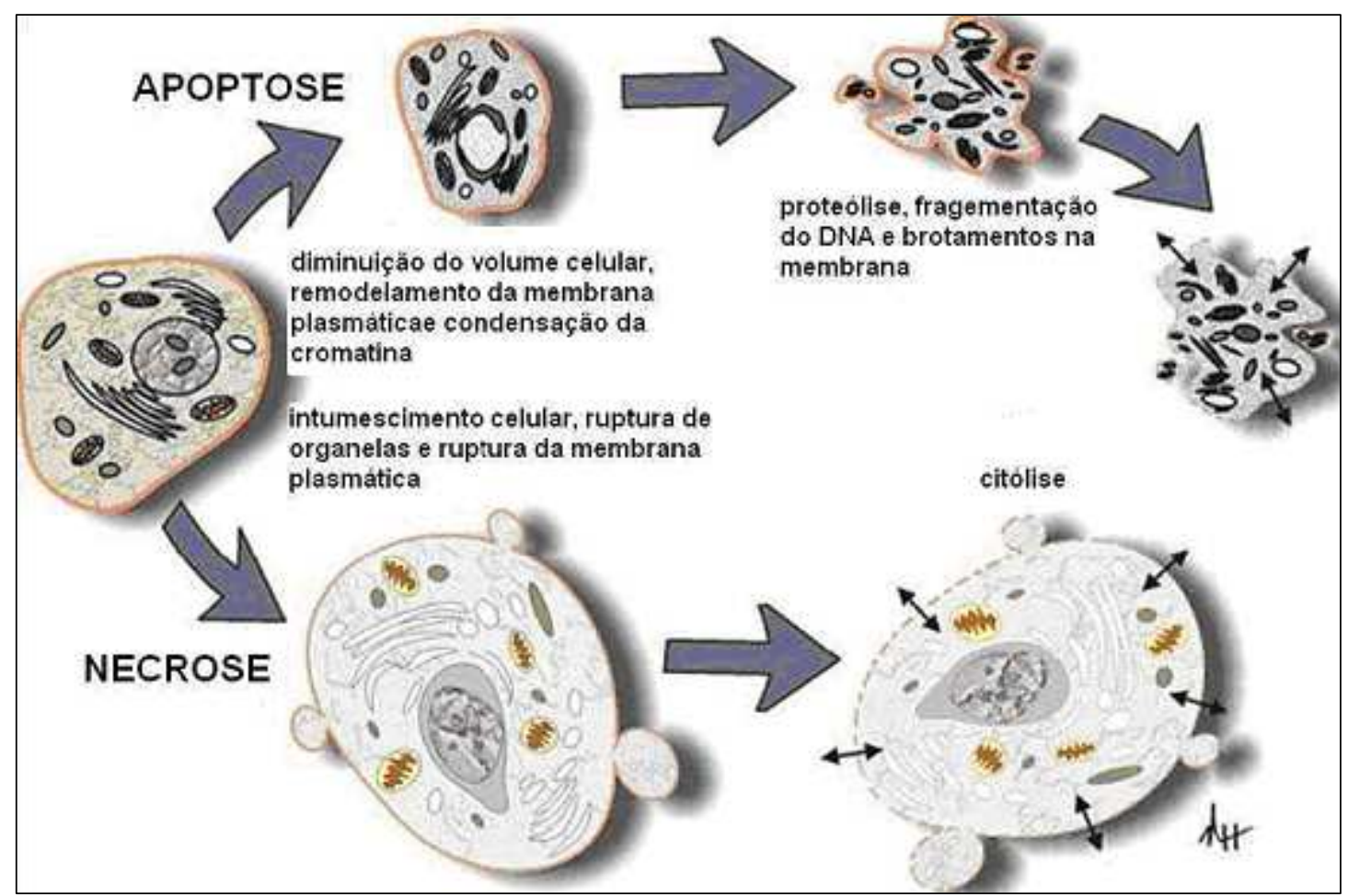

Figura 1 - Características morfológicas de apoptose e necrose

A apoptose pode ser dividida em três fases: de iniciação, efetora e de degradação. A fase de iniciação é altamente dependente do tipo de estímulo apoptótico recebido pela célula por via endógena ou por receptores de superfície com domínios de morte (por exemplo, estresse oxidativo, erros no DNA, desbalanço iônico e presença de citocinas). Esta primeira fase pode influenciar a eficácia das fases seguintes (efetora e de degradação). A fase efetora há ativação da cascata de caspases, constituída da ativação de proteases, nucleases, e de outros intermediários que participam dessa fase. A fase de degradação, na qual a célula adquire as características bioquímicas e morfológicas características desse processo (GREEN; KROEMER, 1998). (Figura1) 
As características ultraestruturas típicas da apoptose são resultantes dos eventos ocorridos nas fases efetora e de degradação: diminuição do volume celular, condensação da cromatina, cariorex, e eventuais brotamentos nas membranas, formando corpos apoptóticos (HAIL et al., 2006; KROEMER; GALLUZZI; BRENNER, 2007;). Há duas vias principais de regulação da apoptose: 1) Apoptose mediada por receptores de morte (TNF, TNFR1, TRAMP, TRAIL e de Fas) presentes na membrana plasmática, denominada via extrínseca e 2) Apoptose mediada pela mitocôndria denominada via intrínseca (HAIL et al., 2006; HAJRA; LIU, 2004;).

Tanto a via extrínseca quanto a intrínseca possuem um grupo independente de caspases iniciadoras que convergem sinais para o mesmo grupo de caspases efetoras com finalidade de executar eventos intracelulares que resultarão na morte celular programada (HAJRA; LIU, 2004; ZHANG et al., 2004). A via extrínseca é iniciada por associação de monômeros de diferentes receptores de morte na membrana plasmática e, ao se agruparem, promovem o recrutamento de proteínas adaptadoras (COHEN, 1997; HAIL et al., 2006).

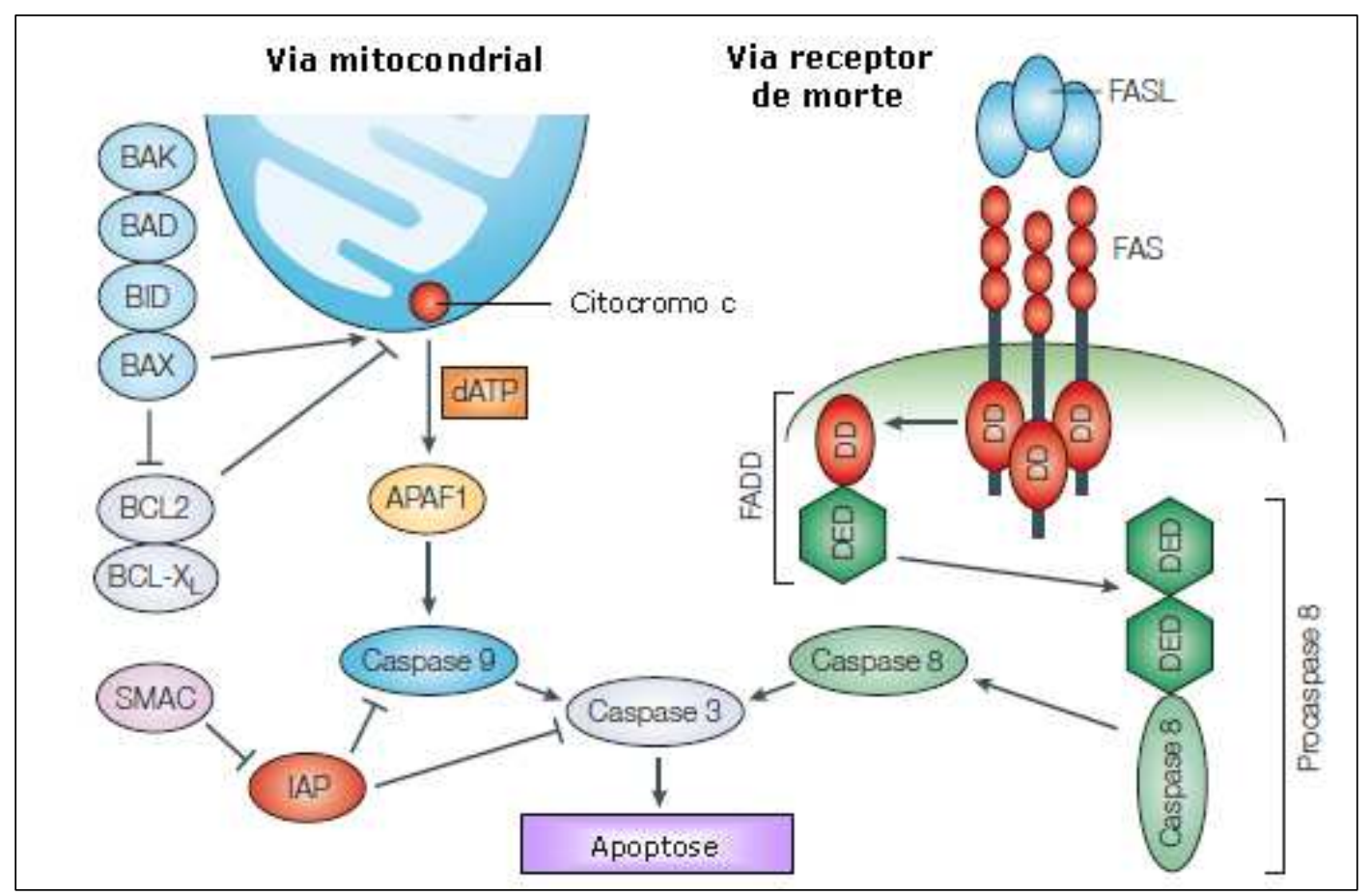

Figura 2- Representação simplificada das duas principais vias envolvidas na apoptose 
A via mitocondrial ou intrínseca envolve alterações na permeabilidade mitocondrial, permitindo o extravasamento do citocromo $\mathrm{C}$, o qual após associar-se a proteínas adaptadoras (APAF-1), culmina na formação do apoptossomo e ativação das caspases 9 e 3 , desencadeando em morte celular por apoptose. As proteínas $B c l-2$ e $B c l-x l$ inibem a liberação do citocromo $C$, enquanto que as proteínas $B A D$, BID e BAX, induzem a liberação dessa molécula. Já a via receptor de morte, ou via extrínseca, caracteriza-se pela ativação de receptores de morte (ex. FAS), os quais uma vez ativados, associam-se a proteínas adaptadoras (ex. FADD), formando o complexo desencadeador de morte DISC que culmina na ativação das caspases $8 \mathrm{e}$ 3, e morte celular por apoptose (Figura 2).

A morte programada ativada pelos receptores de morte celular é desencadeada por membros da superfamília dos receptores de necrose tumoral (TNF), que inclui quase 20 membros receptores de citoquinas, como TNFR1, Faz. Estas proteínas recrutam proteínas adaptadoras, incluindo FADD, com domínios de morte citosólicos vinculado a pro-caspases 3,7 é particularmente a caspase 8 (COWLED; EVDOKIOU ,1998).

O conceito de ciclo celular introduzido em 1953 tem auxiliado no delineamento de diversos eventos que governam a proliferação das células de mamíferos. Durante o ciclo celular podem ser distintas as populações celulares nas seguintes fases: G1 ("Gap 1"), intervalo após a mitose durante o qual as células se preparam para iniciar a síntese de DNA. Este período é caracterizado pela transcrição gênica e tradução, levando à síntese de proteínas necessárias para a síntese de DNA; S período no qual ocorre a duplicação do DNA celular e o G2/M ("Gap 2") intervalo após a síntese de DNA, durante o qual as células se preparam para a divisão e a mitose propriamente dita (SAELENS et al., 2004). 


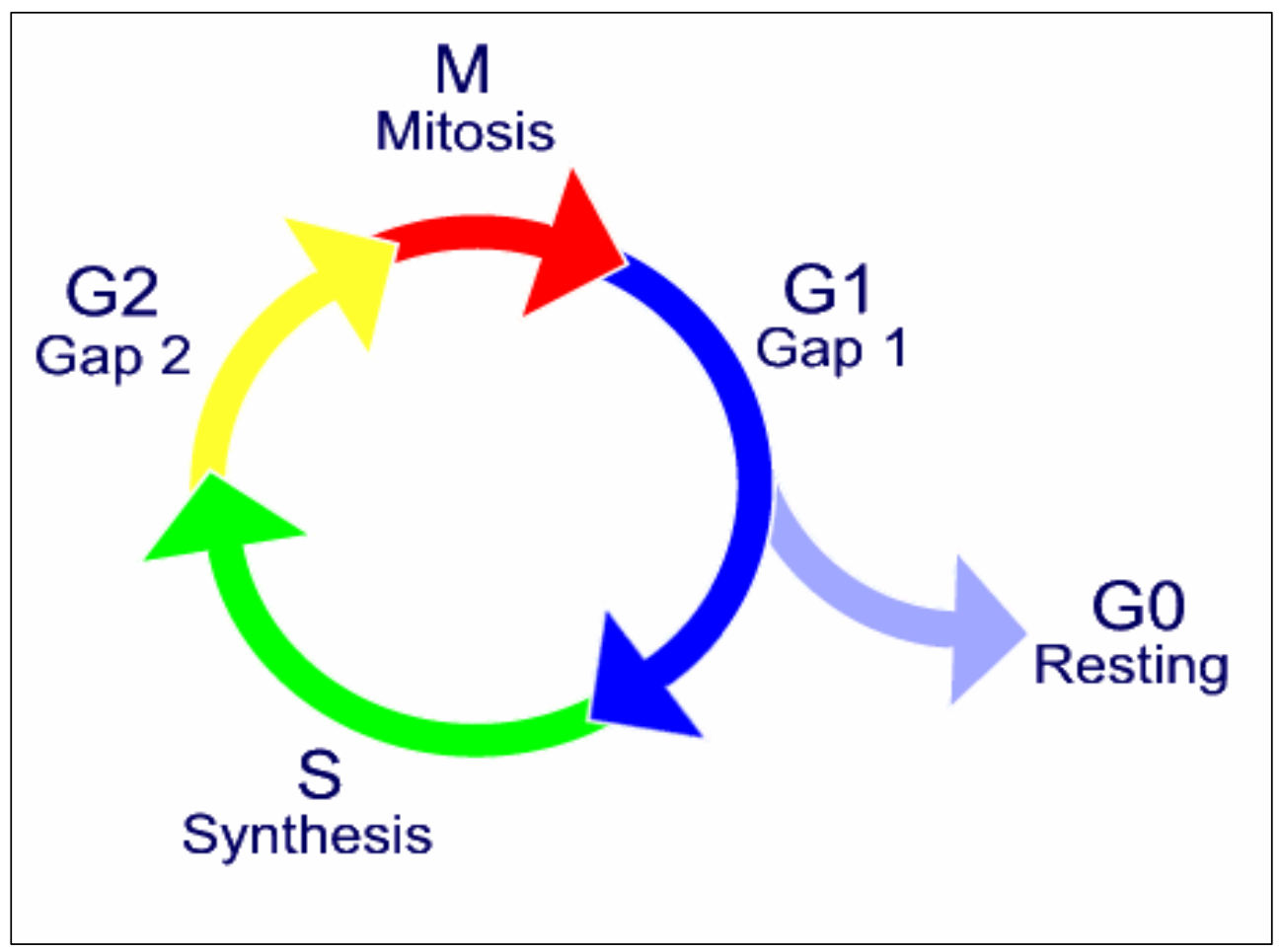

Figura 3 - Esquema ilustrativo das fases do ciclo celular, onde: G0repouso; G1 - Produção de enzimas necessárias para produção de DNA, outras proteínas e RNA; S- síntese de DNA; G2- período pré-mitótico; M- Mitose

O ciclo celular é um processo através do qual uma célula somática duplica seu material genético e o reparte igualmente às suas células-filhas. É didaticamente dividido em duas fases principais: a intérfase e a mitose. Na intérfase ocorre a duplicação do DNA e a preparação para a fase seguinte: a mitose, na qual ocorre a divisão celular propriamente dita, finalidade maior do ciclo celular. A mitose, apesar de ocupar uma pequena parte do ciclo, é crucial para o crescimento e diferenciação do organismo, levando o zigoto às aproximadamente 100 trilhões de células do indivíduo adulto, participando inclusive dos processos de renovação celular (HOWARD; PELC, 1986). Para que o ciclo seja iniciado, uma seqüência ordenada de eventos necessita ocorrer, determinando o processo de divisão: 1) Ligação de um fator de crescimento a um receptor específico na membrana plasmática;2) Ativação deste receptor (proteína transmembrana), que ativa proteínastransdutoras de sinais presentes no citoplasma através do domínio interno do receptor; 3) Transmissão do sinal, por estas proteínas transdutoras, até o núcleo; 4) Ativação de proteínas regulatórias nucleares; 5) Iniciação e progressão do ciclo celular. 
Análises moleculares de cânceres têm revelado que proteínas envolvidas no ponto de checagem G0/G1 - S estão inativas na maioria dos casos, e que alterações no ponto de checagem da ocorrência de danos no DNA parecem ser responsáveis pela resistência das células tumorais a agentes quimioterápicos ou irradiação. Em contraste, alterações no ponto de checagem G2/M são encontradas mais raramente. Algumas alterações no complexo mecanismo regulatório da transição G0/G1- S, maior alvo de alterações em câncer, envolvem deleção ou super expressão de genes ou mutações pontuais que impossibilitam a função gênica, com resultado comum de alteração do balanço fosforilação/desfosforilação, determinando o estado proliferativo da célula (STEBEL et al., 2000).

O controle da proliferação celular ocorre, sobretudo, na fase G1, e a parada do crescimento de células de mamíferos pode ser concluída nesta fase, pela depleção de fatores de crescimento ou soro ou em condições de cultura sob alta densidade celular. $O$ estado de parada de crescimento é alternativamente chamado de repouso, G0 ou fase quiescente do ciclo. A saída do ciclo celular para um estado de parada de crescimento reversível (G0) é um processo ativo que envolve a expressão e atividade de produtos de genes de parada de crescimento. Sob estas condições, um programa intrínseco de expressão gênica é induzido e genes envolvidos na parada de crescimento começam a ser altamente expressos (STEBEL et al., 2000).

Os marcadores reguladores do ciclo celular de reparo e de indução de morte celular programa utilizados foram P53, P21, P27 e ciclina D1. A P53 é um fator de transcrição codificado pelo gene supressor de tumor TP53, expresso constitutivamente na maioria das células e tecidos. Durante a exposição à estress genotóxicos e não genotóxicos, a P53 é ativada atuando como um fator de transcrição ou de repressão de genes que induzem a parada do crescimento, reparo, apoptose ou senescência (MEPLAN; RICHARD; HAINAUT, 2000).

As atividades dos complexos ciclina-CDK são reguladas por fatores chamados inibidores de CDK-s. Existem duas classes principais de inibidores: as familias Cip/Kip e INK-4/ARF. Dentro da família Cip/Kip destacam-se P21, P27 e P53. Esses inibidores funcionam como supressores do tumor e estão frequentemente alterados em tumores. A atividade transcricional de P21 esta sob o controle da proteína P53. A P21 também irá competir com a ciclina D com a mesma 
intenção de provocar a parada do ciclo celular. A P27 responde aos seus supressores de crescimento e irá competir com o complexo E/CDK-2, também provocando uma parada do ciclo celular no ponto de restrição G1/S (SCHWABE et al., 2003)

Os membros da família Bcl-2 regulam a apoptose. Esta família inclui membros pró- apoptóticos (Bax, Bad) e anti-apoptóticos (Bcl-2). A família bcl-2 possui cerca de vinte proteínas já identificadas, cada uma delas com duas ou mais isoformas. Dentre essas proteínas, bax, bak, bcl-Xs, bok, bad, bid exercem função proapoptóticas enquanto as proteínas bcl-2, bcl-XL, bl-w, mcl-1 têm função antiapotótica. $\mathrm{Na}$ mitocôndria, durante a apoptose, algumas modificações dessas proteínas podem ocorrer (ZHANG et al., 2004).

Em muitos estudos marcadores hematopoiéticos como CD34 e Thy-1, embora restritos às células-tronco hematopoiéticas, têm sido usados para identificação e isolamento de progenitores hepáticos. Essas células são caracterizadas pela presença de marcadores hepáticos como (alfa-feto-proteína) AFT, albumina e citoqueratinas (CK) específicas (CK-18 e 19). Fiegel et al. (2003), utilizaram CK18 (marcador hepático) e Thy-1 (marcador hematopoiético) para o isolamento de potenciais populações de células progenitoras hepáticas de fígados de ratos em desenvolvimento. Os mesmos autores demonstraram que as células ovais, que são células-tronco de fígado adulto, também são positivas para esses marcadores fenotípicos (FIEGEL et al., 2006).

O fator de transcrição Oct-3 / 4 (codificado pelo locus Pou5f1) é expresso durante 0 desenvolvimento precoce das células que têm capacidade de diferenciação totipotentes ou pluripotentes (ROSNER et al., 1990). Oct-3 / 4 de proteína presente no núcleo das oito células e todas as células de embriões no estágio de mórula subseqüentes. Quando os embriões se desenvolvem dentro do blastocisto, o trofoectoderma é formada na camada externa dos embriões como a primeira linhagem de células especificação. Oct-04/03 não é expresso pelas células do trofoectoderma, que é a continuação da massa celular interna, o qual mantém a pluripotência (OKAMOTO, et al., 1990). OCT-04/03 regula diversos genes, incluindo FGF-4, UTF1, Sox2, Fbx15, Rex-1 e osteopontina. OCT-4 de transcrição é inicialmente ativo como um fator materno nos ovócitos, mas permanece ativo em embriões durante o período de pré-implantação (SCHOLER et al.,1990). Sua 
expressão está associada a um fenótipo indiferenciado e tumores. Manipulação gênica da expressão knockdown Oct-4 promove a diferenciação, demonstrando assim a um papel desses fatores na auto-renovação de células embrionárias estaminais. Oct-4 pode formar um heterodímero com Sox2, de modo que estes dois se ligam ao DNA de proteínas em conjunto, e induzir a diferenciação de células estaminais (PESCE; SCHOLER, 2001).

NANOG é uma transcrição fator crítico envolvido com auto-renovação de células indiferenciadas as células-tronco embrionárias. Em humanos, esta proteína é codificada pelo gene NANOG, expresso em células-tronco embrionárias (ESC) sendo um fator chave na manutenção da pluripotência (CHAMBERS et al., 2003). NANOG atua em conjunto com outros fatores como POU5F1 e SOX2 envolvidos na auto-renovação de células indiferenciadas as células-tronco embrionárias e na formação de qualquer um dos três folhetos embrionários (endoderma, ectoderma, mesoderma) (PAN; THOMSON, 2007). É por esta razão que a compreensão dos mecanismos que mantêm a pluripotência de uma célula é fundamental para entender como as células-tronco, e pode levar a futuros avanços no tratamento de doenças degenerativas (MITSUI et al., 2003).

A oxidação de lipídios, ou autoxidação, se inicia com a formação de radicais livres, e os hidroperóxidos formados podem causar alterações que podem desencadear a peroxidação e como conseqüência a formação de Espécies Reativas do Metabolismo do oxigênio (ERMO). A membrana é uma das estruturas mais atingidas em decorrência da peroxidação lipídica, que acarreta alterações na estrutura e na permeabilidade das membranas celulares. Consequentemente há perda da seletividade na troca iônica e liberação do conteúdo de organelas, como as enzimas hidrolíticas dos lisossomas, e formação de produtos citotóxicos (como o malonaldeído), culminando com a morte celular. 


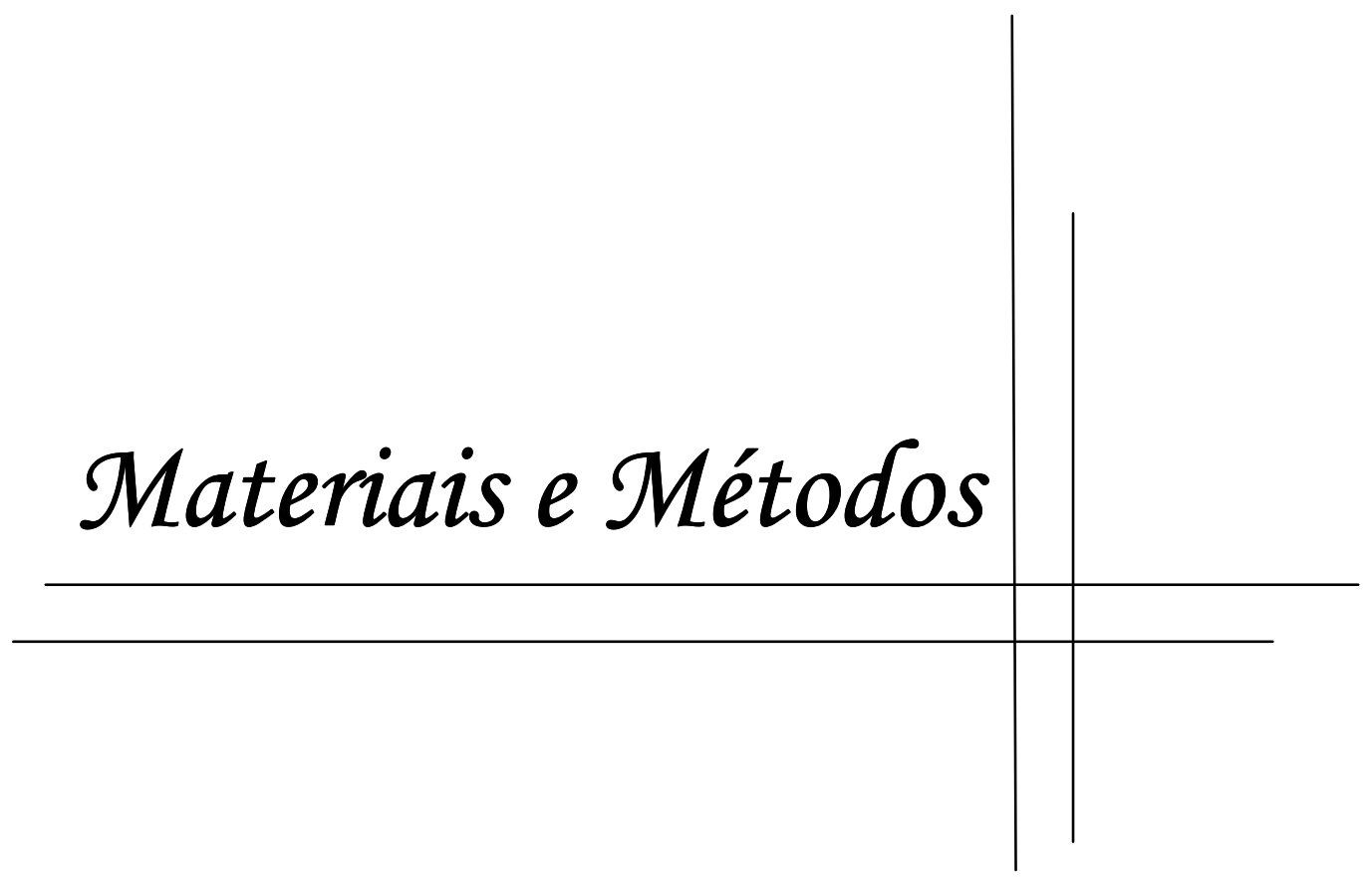




\section{MATERIAIS E MÉTODOS}

As etapas dos materiais e métodos utilizados serão descritos abaixo:

\subsection{Obtenção de célula do broto hepático}

$\mathrm{Na}$ obtenção das células do broto hepático embrionárias e fetais, foram utilizados 40 ratos da linhagem isogênica Fischer 344 do biotério do Instituto Química (IQ - USP)

\subsubsection{Animais e Amostras}

Os ratos da linhagem isogênica Fischer 344, foram alojados no biotério (padrão SPF) do Instituto de Química da Universidade São Paulo (IQ - USP). O material coletado foi processado nos laboratórios do Programa de Pós-Graduação de Anatomia dos Animais Domésticos e Silvestres- Departamento de Cirurgia, FMVZ-USP.

\subsubsection{Acasalamento}

As fêmeas foram alojadas em grupos de três por caixa, os machos foram alojados individualmente. As fêmeas foram transferidas para as caixas dos machos ao final da tarde para pernoite, retiradas na manhã seguinte entre as sete às oito da manhã. Cada fêmea foi avaliada por meio de esfregaços vaginais para averiguação do ciclo estral e presença de espermatozóides, indicativos de acasalamento.

O esfregaço foi realizado com auxílio de swab e colocado sob lâmina histológica para posterior análise em microscópio óptico. A visualização de um ou mais espermatozóides ao microscópio óptico é indicativa de acasalamento, e tendo 
essa indicativa a fêmea acasalada era separada em uma gaiola sozinha para evitar qualquer tipo de estresse durante o período gestacional e a contagem era iniciada 0,5 dias pós a fecundação, assim como o controle de peso e da conformação abdominal das mesmas. Os ratos foram mantidos em ambientes com ciclos de luz e sombra controlados por timer e sob lâmpada fluorescente de 20 watts (Figura 4).

\subsubsection{Colheita do Material}

Os animais foram inicialmente colocados em uma caixa de indução onde receberam isofluorano em oxigênio a $100 \%$. Ao apresentarem sinais de relaxamento muscular, foram retirados da caixa de contenção e a eutanásia foi realizada com auxílio de máscara de tamanho apropriado e o anestésico administrado através de circuito de Magill adaptado para ratos. A confirmação da eutanásia foi pela ausência das freqüências cardíaca e respiratória, reflexo do globo ocular com relaxamento muscular.

Os embriões de 12,5 dias, e os fetos 14,5 e 16,5 dias de gestação, foram coletados por meio de uma incisão pré-retroumbilical nas ratas Fischer 344 prenhe. Identificando os cornos uterinos estes foram removidos da cavidade abdominal. Incisões cirúrgicas nos sacos gestacionais foram realizadas, a fim de promover a exposição dos embriões e fetos, bem como dos anexos. Os embriões e os fetos foram coletados em placas de Petri e lavados com solução de PBS-L, a coleta do broto hepático foi realizada por meio de uma incisão longitudinal no intestino primitivo do embrião com o auxílio das lupas estéreo microscópico e matérias para micro cirurgia (Figura 5).

Todo o material foi coletado sob condições assépticas adequadas, sendo todo o procedimento realizado dentro do fluxo laminar do Laboratório de Cultivo Celular do Programa de Pós-Graduação de Anatomia dos Animais Domésticos e Silvestres da FMVZ - USP. Os materiais utilizados, a superfície de contato e o ambiente foram esterilizados, reduzindo assim as chances de qualquer tipo de contaminação das amostras. 


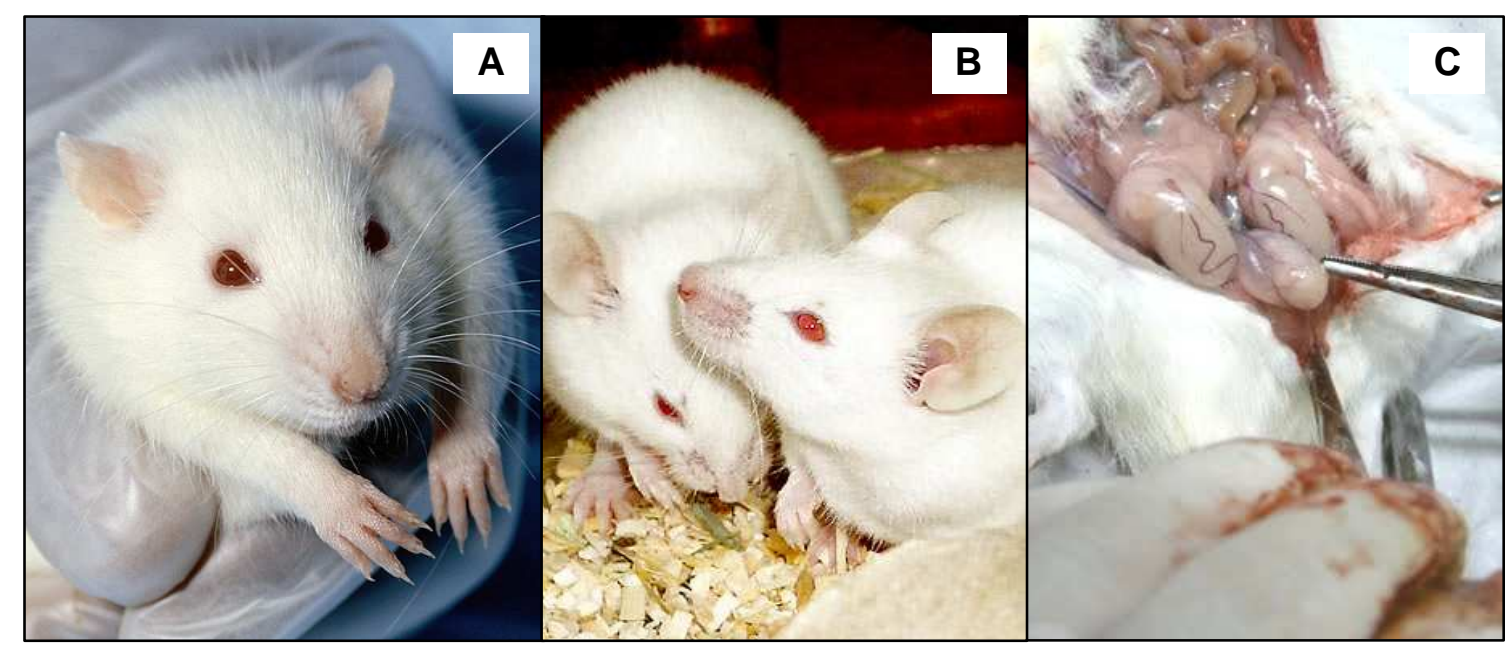

Figura 4 - Fotografia de rato da linhagem isogênica Fischer 344. A e B: aspecto do animal adulto e C: laparotomia exploratória da rata prenhe de 14.5 dias de gestação

\subsubsection{Cultivo Celular}

As amostras (broto hepático) coletadas foram lavadas com solução de PBS. Estas estruturas foram debridados manualmente, com auxílio de uma lâmina de bisturi até a obtenção de um homogeneizado dos fragmentos.

Os fragmentos resultantes foram implantados em garrafas de cultivo, as quais foram previamente preenchidas com meio de cultura: DMEM/F12, 15\% Soro Fetal Bovino (hyclone), $1 \%$ de estreptomicina, penicilina e glutamina. As células foram incubadas a uma temperatura de $37^{\circ} \mathrm{C}$, com umidade relativa próxima de $100 \% \mathrm{e}$ atmosfera gasosa de $5 \%$ de $\mathrm{CO}_{2}$.

O meio utilizado neste trabalho para a expansão das células do broto hepático foi o meio de cultura DMEM F12, suplementado com $1 \%$ de glutamina, $1 \%$ de aminoácidos não essenciais, $1 \%$ de antibiótico e $15 \%$ de soro fetal bovino (hyclone). Após a confluência das garrafas de $25 \mathrm{~cm}^{2}$, as células da garrada foram submetidas à dissociação enzimática das células aderentes por tripsinização, centrifugação, ressuspendidas e recultivadas para novas garrafas com maior superficie para aumento da densidade celular e congelamento para constituição de um banco de células. 

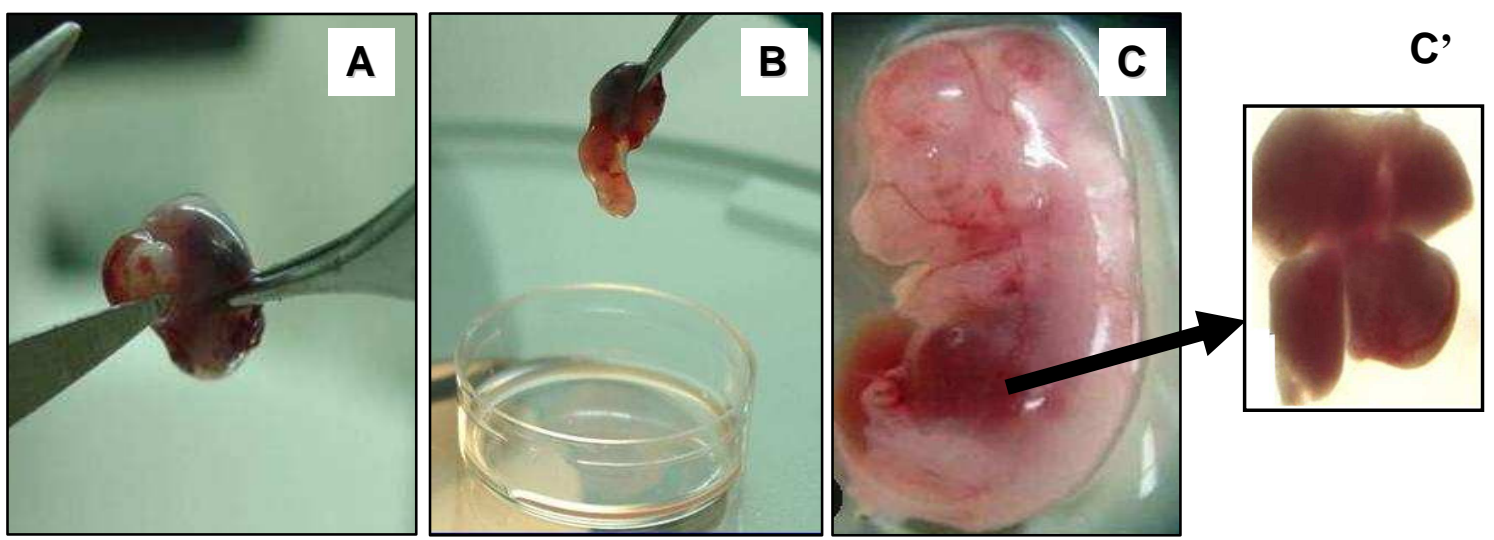

Figura 5 - Isolamento do embrião de rato Fischer 344. A, B e C- Embriões 12,5 dias após o acasalamento isolados da placenta. C- Embrião isolado12,5 dias de gestação e C'- Broto hepático isolado do embrião

\subsubsection{Congelamento Celular para banco de células}

As amostras das suspensões das células do broto hepático nos diferentes estágios embrionário e fetais foram contadas, usando a técnica de coloração, azul de trypan e congelados em tampão citrato (2 mM), sucrose $25 \mathrm{mM}$ e 0,05\% dimetil sulfóxido (DMSO), e mantidas em nitrogênio líquido no LCT ( Laboratório de Célulatronco ) da Faculdade de Medicina Veterinária e Zootecnia da USP até o momento de sua utilização. Neste trabalho foram utilizadas as passagens P3 à P6 das células do broto hepático após o descongelamento.

\subsection{Caracterização morfológica da cultura de células do broto hepático}

Todos os aspectos de crescimento celular foram acompanhados pela fotodocumentação das garrafas em microscopia invertida acopladas a um sistema de captura de imagem CCD- Sony.

As células, cultivadas em placas de Petri sobre lamínulas, foram fixadas em paraformol $4 \%$ por $2 \mathrm{hs}$ e coradas com Hematoxilina-eosina, em seguida fotografadas em microscópio invertido, acoplado a um sistema de captura de imagem CCD- Sony. 


\subsubsection{Microscopia Eletrônica de Varredura}

As células foram cultivadas em placas de Petri de $3 \mathrm{~cm}$ de diâmetro. Após a confluência, o meio de cultivo foi retirado e colocado o fixador glutaraldeído (3\%). Após 2 horas o fixador foi retirado e as placas foram lavadas em água destilada e pós fixadas em tetróxido de ósmio 1\% por 1 hora, seguida de lavagens em água destilada e série crescente de álcool etílico $\left(50^{\circ}-1009\right.$. As placas com o cultivo celular foram secas em estufa $37^{\circ}$. Na seqüência, foram submetidas a um revestimento metálico ("sputting") com ouro no aparelho metalizador EMITECH K550, sendo analisadas e fotografadas em microscópio eletrônico de varredura LEO 435VP do Programa de Pós-Graduação dos Animais Domésticos e Silvestres da FMVZ - USP.

\subsection{Análise das transaminases hepáticas}

As células do broto hepático de ratos foram analisadas bioquimicamente através das transaminases hepáticas (TGO e TGP)

\subsubsection{Quantificação de Concentração de Proteínas Totais}

O método de Bradford é uma técnica para a determinação de proteínas totais que utiliza o corante "Coomassie brilliant blue" BG-250. Este método é baseado na interação entre o corante BG-250 e macromoléculas de proteínas que contém aminoácidos de cadeias laterais básicas ou aromáticas. No pH de reação, a interação entre a proteína de alto peso molecular e o corante BG-250 provoca o deslocamento do equilíbrio do corante para a forma aniônica, que absorve fortemente em $595 \mathrm{~nm}^{46}$.

A determinação da concentração de proteínas totais foi realizada a partir de uma curva-padrão com concentrações de uma solução de albumina que variam de 2,5 á $25 \mu \mathrm{g} / \mathrm{mL}$. Através dos valores de absorbância obtidos confeccionou-se curva- 
padrão e determinou-se a equação da reta. Assim, obtivemos os valores respectivos das concentrações das amostras a partir das respectivas absorbâncias.

As células do broto hepático ( $\mathrm{CBH} 12,5$ dias; $\mathrm{CBH}$ 14,5 dias e $\mathrm{CBH} 16,5$ dias) foram cultivadas em meio DMEN- F12, suplementado com $15 \%$ de soro fetal bovino e antibióticos, em placas de 6 orifícios com a concentração inicial de $1 \times 10^{5}$ células/mL por 24 horas para adesão e confluência celular. Após este período, 0 meio de cultura foi removido, as células foram tripsinizadas, recolhidas em um microtubo e em seguida foi adicionado o mesmo volume de tampão PBS com 10\% de soro fetal bovino. As amostras foram centrifugadas por 10 minutos á 1500 rpm e os sobrenadantes descartados. Ao pellet resultante foi adicionado $200 \mu \mathrm{L}$ de PBS e os microtubos foram mergulhados em nitrogênio líquido por 1 minuto para rompimento das membranas celulares. As amostras foram centrifugadas por 15 minutos á 8000 rpm e os sobrenadantes recolhidos. Em um microtubo foi adicionado $700 \mu \mathrm{L}$ de tampão PBS, $100 \mu \mathrm{L}$ do sobrenadante recolhido e $200 \mu \mathrm{L}$ do reagente de Bradford. Após agitação moderada, a leitura foi realizada no espectrofotômetro no comprimento de onda de 594nm.

Os valores de proteínas totais foram expressos em microgramas por mililitro $(\mu \mathrm{g} / \mathrm{mL})$.

\subsubsection{Transaminase glutâmico oxalacética hepáticas (TGO)}

Exames laboratoriais bioquímicos complementares são imprescindíveis para avaliar a capacidade funcional de órgãos vitais, como também em diversas situações de neoplasias e a sua relação determina os índices de proliferação celular.

No entanto, níveis elevados das enzimas hepáticas aspartato aminotransferase (AST) e alanina aminotransferase (ALT) indicam severos danos ao fígado. Estas enzimas foram analisadas com o kit da Bioclin®.

Foi utilizado o método colorimétrico .O substrato para TGO foi composto pelo tampão fosfato $0,1 \mathrm{~mol} / \mathrm{L} \mathrm{pH} 7,4$, ácido $\mathrm{L}$ aspártico $0,153 \mathrm{~mol} / \mathrm{L}$, ácido alfa cetoglutárico $2 \mathrm{mmol} / \mathrm{L}$ e azida sódica 7,7mmol/L. Alíquota de $100 \mu \mathrm{L}$ das amostras dos diferentes períodos de gestação foram homogeneizada e incubada a $37^{\circ} \mathrm{C}$ por 
30 minutos com $250 \mu \mathrm{L}$ do substrato a $37 \square \square \mathrm{c}$ e após adicionado $250 \mathrm{~mL}$ de 2,4dinitrofenilhidrazina $1,0 \mathrm{mmol} / \mathrm{L}$ e ácido clorídrico $1,0 \mathrm{~mol} / \mathrm{L}$, Alíquotas de $250 \mu \mathrm{L}$ foram Transferida para as cubetas e medido a absorbância ou transmitância em 505 nm (490-540), acertando o zero com água destilada ou deionizada. A cor é estável por 30 minutos. Foi calculado os valores de TGO através da curva de calibração. Se o resultado obtido for acima de 180 unidades, diluir a amostra com $\mathrm{NaCl}$ 0,85\% e proceder-se nova determinação. $O$ valor obtido foi multiplicado pelo fator de diluição e a quantidade foi expressa em V/L.

\subsubsection{Transaminase glutâmico pirúvica hepática (TGP)}

A técnica utilizada foi a mesma da anterior, com apenas algumas diferenças. O substrato utilizado foi tampão Fosfato $0,1 \mathrm{~mol} / \mathrm{L} \mathrm{pH} \mathrm{7,4,} \mathrm{L-Alanina} 0,2 \mathrm{~mol} / \mathrm{L}$, Ácido Alfa Cetoglutárico $2 \mathrm{mmol} / \mathrm{L}$ e azida sódica $7,7 \mathrm{mmol} / \mathrm{L}$. e incubado a $37 \mathrm{c} \mathrm{com}$ $250 \mu \mathrm{L}$ das amostras de $\mathrm{CBH}$ das diferentes idades de gestação..Homogeneizar e deixar em repouso por 20 minutos a temperatura ambiente. A reação foi bloqueada pela adição de hidróxido de Sódio. Homogeneizado por inversão e deixar em repouso por 5 minutos à temperatura ambiente. Alíquotas de 250 ul foram transferidas para as cubetas e medidas a absorbância ou transmitância em 505 nm, Os valores de TGP foram obtidos através da curva de calibração. Se o resultado obtido for acima de 140 unidades para Transaminase Pirúvica, a amostra foi diluída em solução salina e procedeu-se nova leitura. O valor obtido foi multiplicado pelo fator de diluição.

\subsection{Análises de marcadores por citometria de fluxo}

Após o crescimento e expansão celular, as células em cultura foram tripsinizadas e inativadas com Soro Fetal Bovino (Hyclone $\left.{ }^{\circledR}\right)$, colocada em tubos de $15 \mathrm{~mL}$ em câmara de fluxo laminar previamente esterilizada com álcool $70 \%$ e UV durante 20 minutos. Em seguida o material foi centrifugado à 1500rpm durante 10 
minutos para a formação do precipitado celular. Após a centrifugação, foi descartado o sobrenadante e ressuspendido em $5 \mathrm{ml}$ solução salina $0,9 \%$ para lavagem, centrifugado à $1500 \mathrm{rpm}$ durante 10 minutos. Após a centrifugação foi descartado novamente o sobrenadante e acrescentado o tampão FACs Flow, a suspensão foi transferida para tubos de citometria, e adicionados os anticorpos Ck-8, Ck-18, Desmina, STRO-1, CD90, OCT3/4, Nanog, Ciclina D1, P53, P21, P27, Bax, Bad, Bcl-2, Caspase-3 e Anexina V/PI; incubados por 15 minutos a 4ํㅡ. Análises de expressão foram realizadas em Citômetro de Fluxo FACSCalibur em 10.000 eventos, e as aquisições analisadas pelo programa Win Mdi 2.8. A expressão de marcadores foi determinada pela comparação com um isotipo controle marcado com o fluorocromo FITC inespecífico.

A avaliação da expressão anticorpos citoplasmáticos e nucleares Oct 3/4, Stro1, Nanog, Ciclina D1, Bax, Bad, P21, P27, P53 e CD90, as células foram permeabilizadas previamente com $10 \mu \mathrm{l}$ de Triton X-100 (0,1\%) por 30 minutos antes da adição dos anticorpos primários específicos e após 2 horas foi adicionado o anticorpo secundário (Alexa-Fluor 486 - Invitrogen) marcado com FITC.

\subsubsection{Marcadores de Células Mesenquimais}

Após o crescimento e expansão das culturas, as células do broto hepático foram incubadas com os seguintes marcadores de células mesenquimais:

- CD90 (R\&D Syatems): Marcador expresso em uma série de linhagens celulares fibroblásticas e estromais, endotélio, e algumas linhagens celulares tumorais. Está envolvido na adesão e migração (SICLARI; QIN,2010).

- STRO-1 PE (Santa Cruz): Marcador de superfície expresso em células-tronco mesenquimais (SICLARI; QIN,2010).

- OCT3/4 e NANOG (Santa Cruz): determinante de células-tronco embrionárias e germinativas são fatores de transcrição envolvidos na regulação da supressão de genes que levam a diferenciação e manutenção da pluripotência (SICLARI; QIN, 2010). 


\subsubsection{Marcadores de Citoesqueleto}

Após o crescimento e expansão das culturas, as células do broto hepático foram incubadas com os seguintes marcadores de citoesqueleto:

- CK-8 (Santa Cruz): Citoqueratina 8, baixo peso molecular, anticorpo monoclonal marca as células epiteliais não escamosas.

- CK-18 (Santa Cruz): Citoqueratina de baixo peso, marca células do epitélio ductal e glandular.

- DESMINA (M.D): marcador de células musculares lisas, estriadas cardíacas e esqueléticas.

\subsubsection{Marcadores Envolvidos na Checagem e Progressão do Ciclo Celular}

Após o crescimento e expansão das culturas, as células do broto hepático foram incubadas com os seguintes marcadores reguladores dos pontos de checagem e progressão do ciclo celular:

- P21 e P27 FITC (Santa Cruz): Proteínas envolvidas na progressão do ciclo celular, reguladora da transição da fase G1-S e G2-M consecutivamente (COQUERET, 2003).

- P53 PE (Santa Cruz): Atua impedindo a progressão do ciclo celular na transição G1/S, na presença de danos à molécula de DNA. A expressão de proteína P53 e sua mutação estão associados com o pobre diagnóstico em neoplasias (TRIEB; KOTZ, 2000).

- Ciclina D1 (Santa Cruz): Proteína reguladora das CDK's (quinases dependente de ciclinas), envolvidas na fase G1/S. A amplificação ou aumento da expressão altera a progressão do ciclo celular (COQUERET,2003). 


\subsubsection{Marcadores Envolvidos na Morte Celular}

Após o crescimento e expansão das culturas, as células do broto hepático foram incubadas com os seguintes marcadores envolvidos na morte celular:

- Bax (Santa Cruz) e Bad (Cell Signaling): Proteínas pró-apoptóticas (CHORNA; DATSYUK; STOIK,2005).

- Bcl-2 (Santa Cruz): Proteína anti-apoptótica, pois inibe a liberação do citocromo-c (CHORNA; DATSYUK; STOIK,2005).

- Anexina V/PI (Southern Biotech): indicam morte celular por apoptose (Anexina V) ou necrose (PI) (GRIVICICHI; REGNER; ROCHA, 2007).

- Caspase-3 FITC (Santa Cruz): indicam morte celular por apoptose (GRIVICICHI; REGNER; ROCHA, 2007).

\subsubsection{Análise do Potencial Elétrico Mitocondrial}

Para a análise do potencial de membrana mitocondrial $(\Delta \psi \mathrm{m})$ foi utilizado o fluorocromo Rodamina 123 (Invitrogen, EUZ). A mitocôndria é uma organela citoplasmática relacionada ao metabolismo energético. Na membrana mitocondrial interna, está localizada a cadeia transportadora de elétrons que produz energia a partir do fluxo de elétrons e consequente fosforilação oxidativa. A Rodamina 123 é uma sonda fluorescente que é captado quando elétrons são doados para a cadeia respiratória. Quando o gradiente eletroquímico é formado, a Rodamina 123 é captada ocorrendo a diminuição da emissão de sua fluorescência. A Rodamina 123 permeia a membrana da mitocôndria e inibe processos de transporte, especialmente a cadeia transportadora de elétrons, retardando a respiração interna.

As células do broto hepático dos ratos Fischer 344 foram tripsinizadas e centrifugadas a 1500rpm, por 10 minutos, o sobrenadante foi descartado, e adicionas $5 \mu \mathrm{L}$ de Rodamina $123(5 \mathrm{mg} / \mathrm{mL})$. A seguir, as células foram incubadas em estufa de $\mathrm{CO}^{2}(5 \%)$, a $37^{\circ} \mathrm{C}$ por 30 minutos. Após este período, os tubos foram centrifugados, o sobrenadante foi descartado e o precipitado foi ressuspendido em 
10 $\mu \mathrm{L}$ de solução tampão para citometria, Fac's Flow (BD). A análise da marcação com a Rodamina 123 nas células hepáticas foi realizada em citômetro de fluxo FACScalibur (BD) pela aquisição de 10.000 eventos. Os dados foram analisados pelo programa Win MDI 2.8.

\subsubsection{Análise das fases do Ciclo Celular}

As células em cultivo foram tripsinizadas, centrifugadas durante 10 minutos à 15000 rpm, o sobrenadante foi descartado, e as células ressuspendidas em tampão para citometria (FACS FLOW- BD). As células foram centrifugadas novamente durante 3 minutos à 2000rpm e descartado o sobrenadante. As células foram cuidadosamente ressuspendidas em $1 \mathrm{ml}$ de etanol 70\% RNAse, transferidas para microtubos e armazenadas à uma temperatura de $-20^{\circ} \mathrm{C}$.

\subsubsection{Incorporação do lodeto de Propídio (PI) e Leitura das Amostras}

As amostras fixadas e armazenadas previamente foram centrifugadas à 2000rpm por 5 minutos. O sobrenadante foi descartado, as células ressuspendidas em $1 \mathrm{ml}$ de tampão de citometria e centrifugadas novamente. Após a centrifugação, o sobrenadante foi descartado e as células ressuspendidas em solução de PI, preparada a partir de $5 \mathrm{~mL}$ de PBS (tampão fosfato de sódio $\mathrm{pH}=7,4$ ), ao qual foram adicionados $5 \mu \mathrm{L}$ de Triton $100(0,01 \% \mathrm{v} / \mathrm{v}), 50 \mu \mathrm{L}$ de RNAse A $(2 \mathrm{mg} / \mathrm{mL})$ e $20 \mu \mathrm{L}$ de iodeto de propídio $(5 \mathrm{mg} / \mathrm{mL})$. Em seguida realizou-se a aquisição dos dados em Citômetro de Fluxo FACSCalibur em 10.000 eventos, e para análise foi utilizado o programa Win Mdi 2.8. 


\subsubsection{Interpretação dos Resultados}

O lodeto de Propídio (PI) é um fluorocromo que se intercala estequiometricamente às duplas fitas de DNA. A fluorescência foi captada em FL-2, e ela é proporcional ao conteúdo de DNA na célula. Células diplóides que não estejam replicando (fases G0/G1 do ciclo celular) possuem conteúdo de células 2n, emitindo sinais de menor intensidade que as células situadas na fase $S$, durante a qual ocorre o aumento do conteúdo de DNA. Células em fase $S$, por sua vez, geram sinais de menor intensidade que aquelas situadas em G2/M até que completem a replicação do conteúdo de DNA para $4 \mathrm{n}$, que permanece assim durante a fase G2 até a mitose, na qual cada célula mãe da origem a duas células filhas.

As células situadas no pico hipodiplóide (Sub-G1) possuem conteúdo de debris celulares e DNA fragmentado, característicos de eventos de morte celular.

Todos os sinais gerados são amplificados e convertidos pelo aparelho em pulsos, permitindo a construção dos gráficos de distribuição das células no ciclo celular. Considerando a existência de uma relação proporcional entre o aumento do conteúdo de DNA e a área do pulso gerado.

\subsection{Determinação in vitro de produtos de radicais peroxidados dos lipídios poliinsaturados}

Os sobrenadantes das culturas celulares utilizadas após a confluência em média de $80 \%$ para a metodologia do MTT, foram recolhidos antes do teste de citotoxicidade MTT e congeladas imediatamente a $-20^{\circ} \mathrm{C}$ até o momento da análise da peroxidação lipídica.

A quantificação da peroxidação de lipídeos em culturas celulares é baseada na formação de substâncias reativas ao ácido tiobarbitúrico (TBARs), ${ }^{\text {ohkawa }}$ predominantemente o malondialdeído (MDA), que ocorre após a lipoperoxidação das membranas celulares. Estas substâncias produzem uma coloração característica que é medida espectrofotometricamente. 
As amostras foram descongeladas em temperatura ambiente. Em microtubo foi adicionado $50 \mu \mathrm{L}$ da amostra com $250 \mu \mathrm{L}$ de ácido tricloroacético (TCA) $20 \%$. Em outro microtubo, $50 \mu \mathrm{L}$ da mesma amostra foi adicionada juntamente com $250 \mu \mathrm{L}$ de ácido tiobarbitúrico - TBA 0,86\%. Os microtubos foram colocados em banho-maria $\left(100{ }^{\circ}\right)$ ) por 20 minutos, seguido de resfriamento á $0^{\circ} \mathrm{C}$ por 20 minutos. Os microtubos foram centrifugados á 8000 RPM por 4 minutos e o sobrenadante foi utilizado para a quantificação das TBARS. A leitura foi realizada em espectrofotômetro no comprimento de onda de 535nm.

O cálculo da medida de lipoperoxidação foi realizado descontando o valor do branco respectivo de cada série, subtraindo a absorbância da série de TBA da média da série de TBA e dividindo-se pelo coeficiente molar do MDA. Os resultados foram expressos em nmoles de MDA por mililitro.

\subsection{Análise Estatística}

As análises estatísticas foram realizadas pelo método de Variância ANOVA seguido de teste comparativo múltiplo de TUKEY-KRAMER. Os valores foram expressos em média \pm desvio padrão, considerando-se como valores significantes $\mathrm{p}<0.05$. 
Resultados

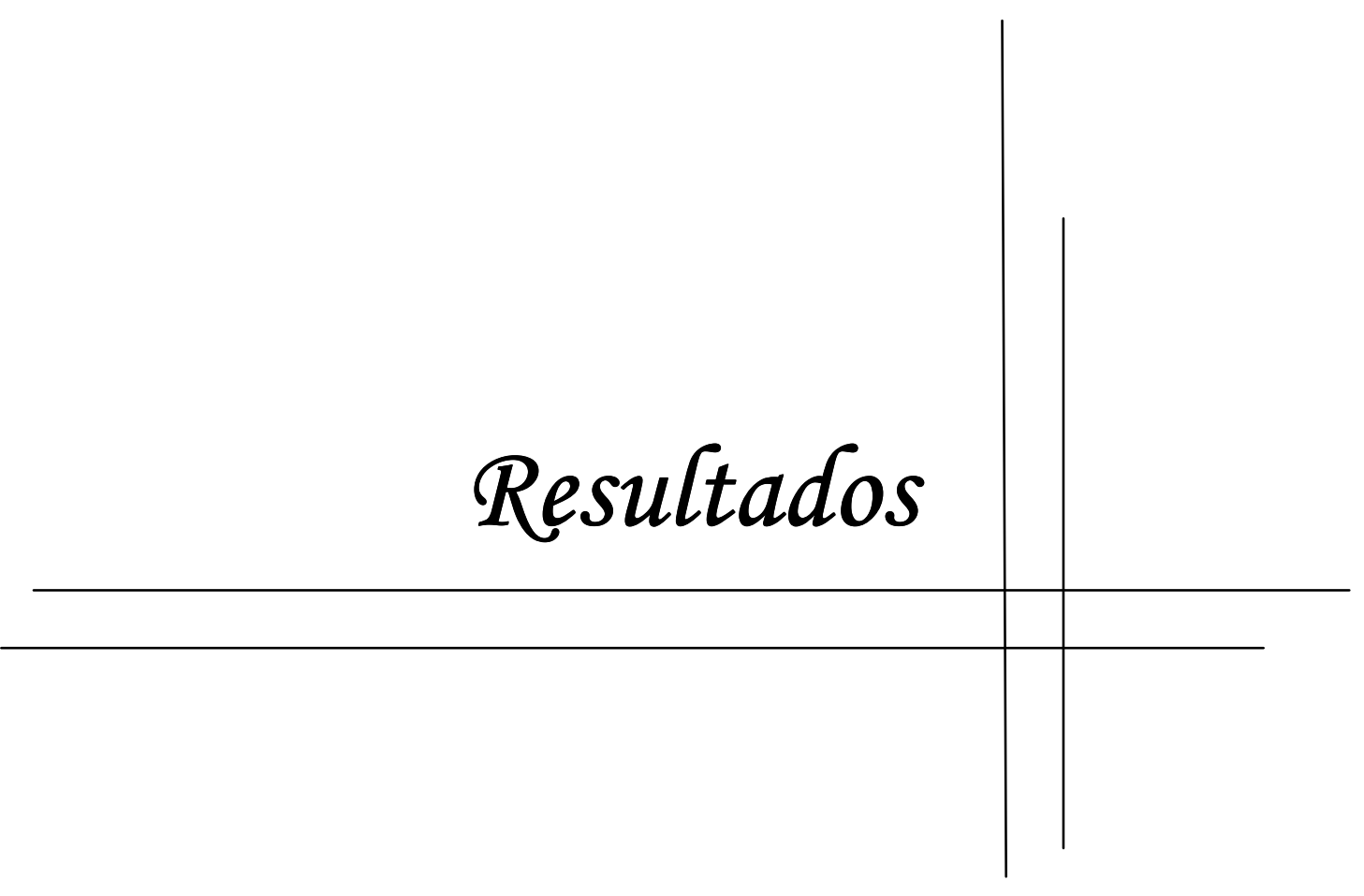

69 


\section{RESULTADOS}

Os resultados obtidos foram descritos de acordo com a metodologia aplicada.

\subsection{Obtenção de célula do broto hepático}

Os resultados da obtenção das células do broto hepático para o cultivo celular estão descritos abaixo:

\subsubsection{Acasalamentos}

As fêmeas foram alojadas em grupos de três em gaiolas plásticas. Os machos foram alojados individualmente e transferidos para as caixas das fêmeas ao fim da tarde para per noite, sendo retirados na manhã seguinte. Foram realizados lavados vaginais para verificação do ciclo estral e presença de espermatozóides indicativos de acasalamento.

Os ratos foram mantidos em ambiente com ciclos de luz e sombra controlados por timer e sob lâmpada fluorescente de 20 watts. As combinações de diferentes fotoperíodos aos quais machos e fêmeas foram submetidos foram testadas em três fases:

Fase 1: As fêmeas foram separadas e submetidas a 3 diferentes fotoperíodos:

- grupo 1; fotoperíodo de $12 \mathrm{hs}$;

- grupo 2; fotoperíodo de $14 \mathrm{hs}$;

- grupo 3; fotoperíodo de $16 \mathrm{hs}$. Os machos foram mantidos em fotoperíodo de $12 \mathrm{hs}$.

Fase 2: Machos e fêmeas em diferentes fotoperíodos nas seguintes combinações:

- grupo 4 - machos fotoperíodo $16 \mathrm{hs}$ e fêmeas fotoperíodo $12 \mathrm{hs}$; 
- grupo 5 - machos fotoperíodo $16 \mathrm{hs}$ e fêmeas fotoperíodo $16 \mathrm{hs}$;

- grupo 6 - machos fotoperíodo $14 \mathrm{hs}$ e fêmeas fotoperíodo $14 \mathrm{hs}$.

Fase 3: Machos e fêmeas em diferentes fotoperíodos nas seguintes combinações:

- grupo 7 - machos fotoperíodo $14 \mathrm{hs}$ e fêmeas fotoperíodo $12 \mathrm{hs}$;

- grupo 8 - machos fotoperíodo $14 \mathrm{hs}$ e fêmeas fotoperíodo $16 \mathrm{hs}$;

- grupo 9 - machos fotoperíodo $16 \mathrm{hs}$ e fêmeas fotoperíodo $14 \mathrm{hs}$.

O 'N" dos grupos de 1 a 9 foram os seguintes: grupo 1: 67; grupo 2: 27; grupo 3: 31; grupo 4: 25; grupo 5: 27; grupo 6: 25; grupo 7: 21; grupo 8: 18; grupo 9: 21. As combinações de diferentes fotoperíodos aos quais machos e fêmeas foram submetidos apresentaram os seguintes índices de prenhez: grupo 1: 4,5\%; grupo 2 : 14,9; grupo 3: 22.7\%; grupo 4: 8,0\%; grupo 5: 7.4\%; grupo 6: $13.1 \%$; grupo 7 : 14.3\%, grupo 8: 44.5\% e grupo 9: 9.5\%. O Gráfico dos resultados dos acasalamentos se encontra no gráfico 1 .

\section{ÍNDICE ACASALAMENTOS}

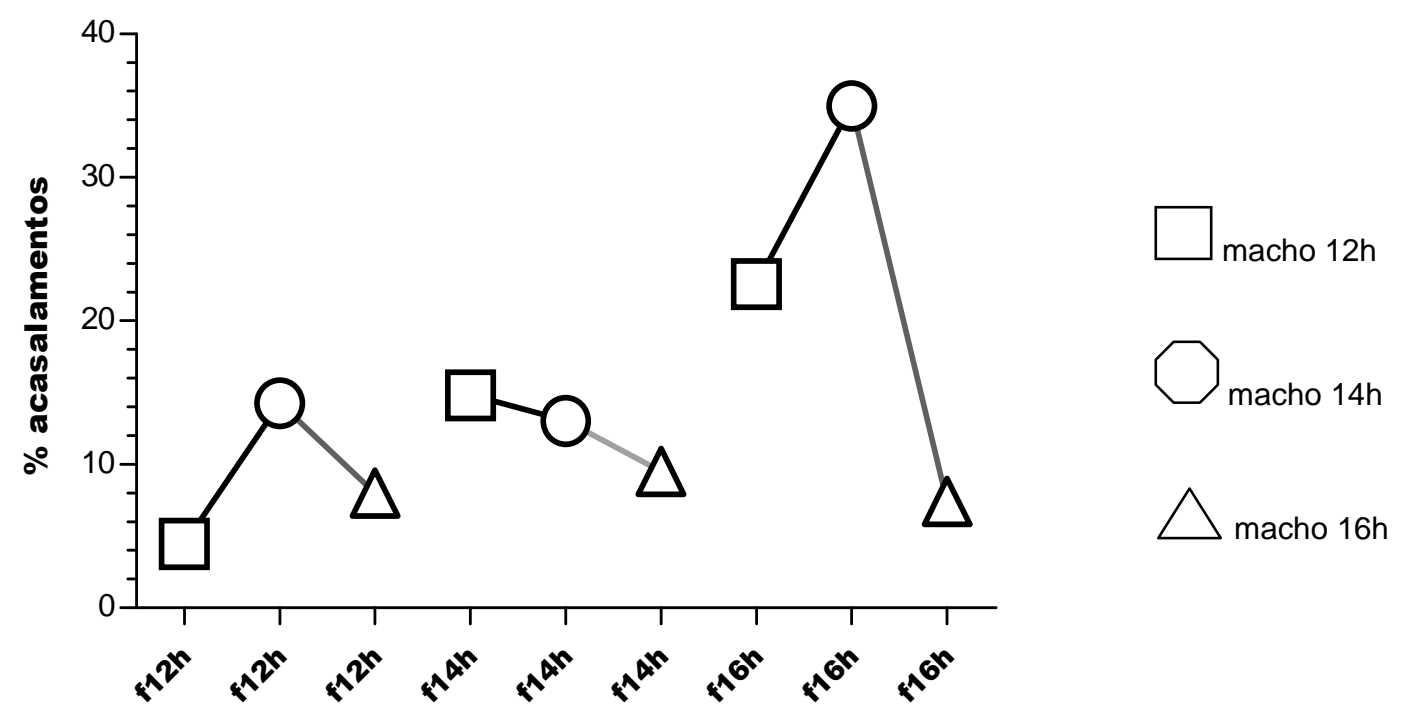

Gráfico 1- Gráfico contendo os índices reprodutivos das ratas da linhagem Fischer 344 à medida que foi modificado o fotoperíodo da fêmea 


\subsubsection{Isolamento e separação do broto hepático dos embriões e fetos de ratos Fischer 344}

$O$ isolamento dos embriões e fetos dos ratos nos diferentes dias gestacionais (12,5; 14,5 e 16,5 dias) foi realizado após a retirada do útero gravídico cavidade abdominal das fêmeas e sua lavagem em solução de PBS com $3 \%$ da solução estreptamicina/ penicilina. Para a coleta do broto hepático, os sacos gestacionais foram abertos sob lupa estereoscópica situado dentro de fluxo laminar para evitar possíveis contaminações. Os embriões a partir 12,5 dias possuiam um tamanho, que proporcionava o adequado isolamento do broto hepático (Figura 6). 0 embrião foi separado de suas membranas por divulcionamento, com auxílio de duas agulhas de seringa de insulina. Após esse divulcionamento, os embriões foram lavados novamente com PBS adicionados com $3 \%$ de antibióticos (Figura 7).

O broto hepático do embrião12,5 já se encontrava como 4 pequenos segmentos, sendo encontrado 2 segmentos em cada lado, entretanto sua forma não se assemelhava com a de um fígado adulto. Os brotos hepáticos dos fetos em 14,5 (Figura 8), 16,5 dias de gestação já apresentavam-se maiores do que os embriões em 12,5.dias.

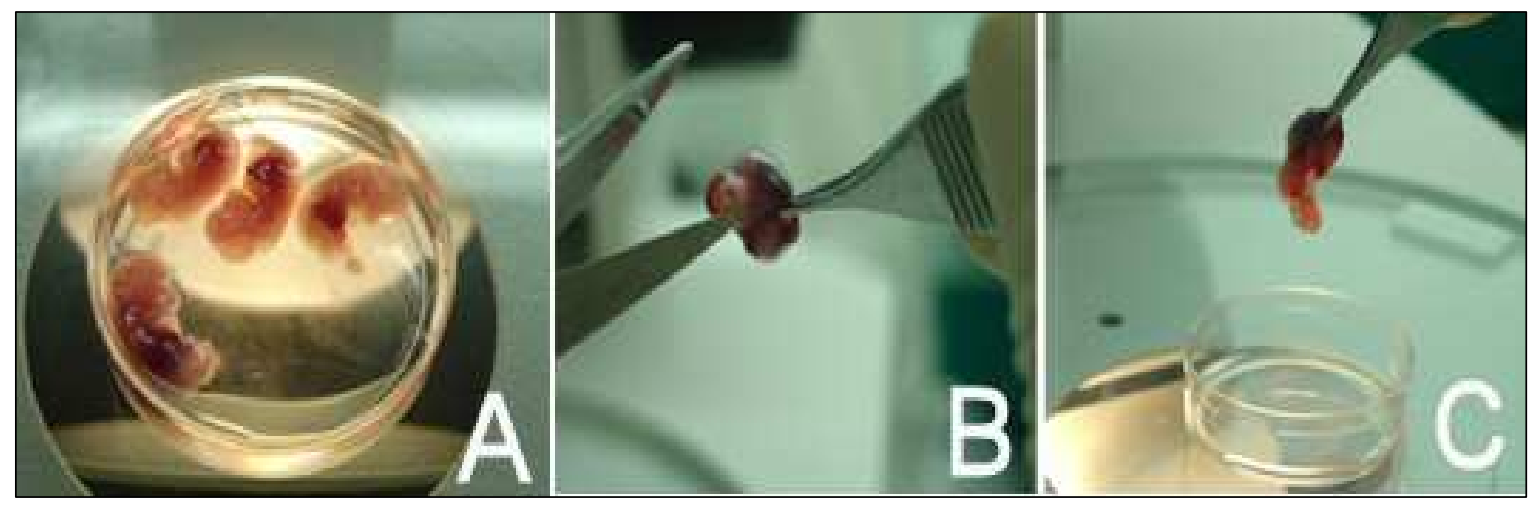

Figura 6- Isolamento do embrião de rato da linhagem Fischer 344. A- Fetos com 16,5 dias após acasalamento. B e C- Embriões em 12,5 dias após 0 acasalamento isolados da placenta 


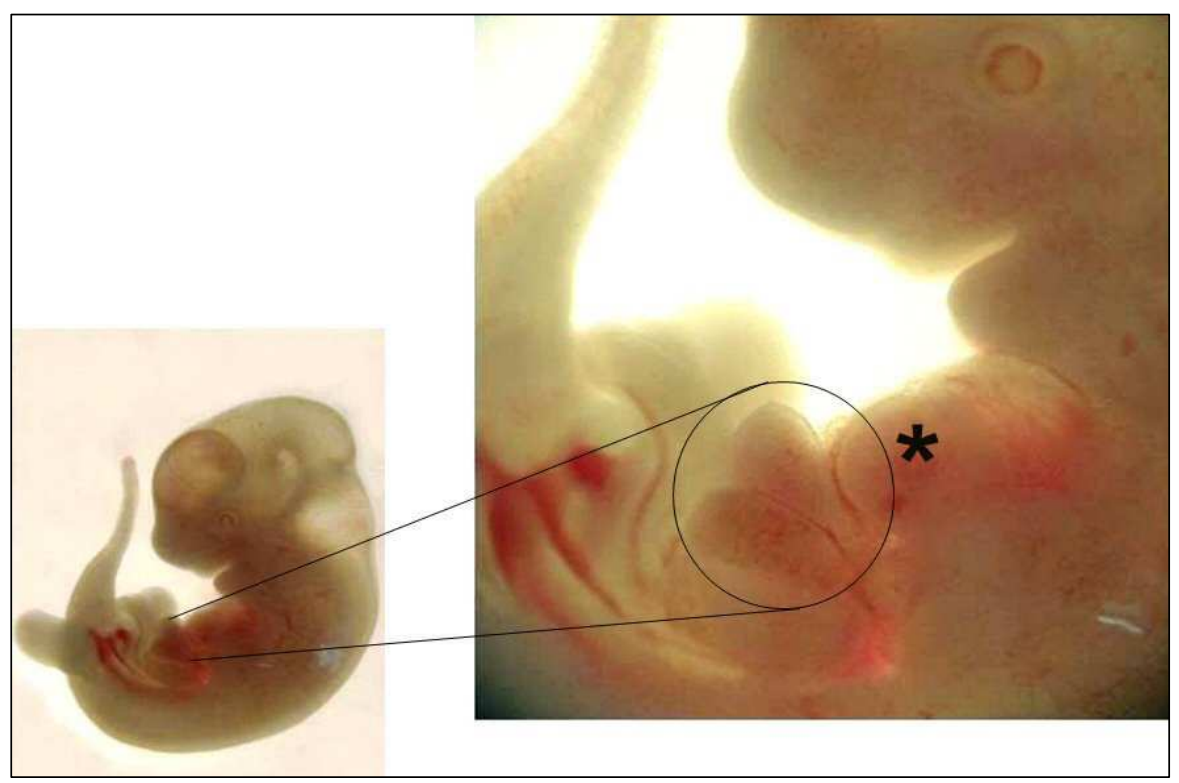

Figura 7- Broto hepático de um embrião de rato Fischer 344 12,5 dias após o acasalamento. Nota-se presença de 4 segmentos estando 2 segmentos de cada lado do embrião. O broto hepático neste período gestacional encontra-se logo abaixo do coração como evidenciado na foto $\left(^{*}\right)$

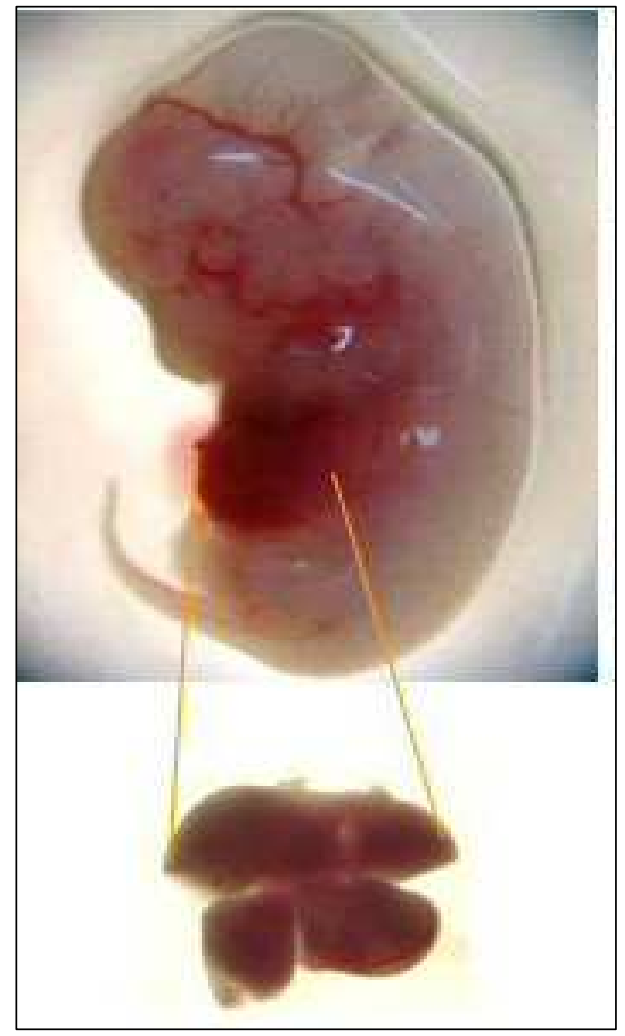

Figura 8- Feto de rato da linhagem F344, a fresco de 14,5 dias de gestação. Nota-se em detalhe o fígado isolado 


\subsection{Caracterização dos aspectos morfológicos das células do broto hepático}

Os resultados da caracterização dos aspectos morfológicos das células do broto hepático estão descritos a seguir:

\subsubsection{Fotodocumentação do Cultivo Celular}

Após a obtenção das células do broto hepático dos embriões e fetos, foram analisados os aspectos morfológicos do cultivo celular através da fotodocumentação das garrafas de culturas em microscópio invertido.

As fotomicrografias das células do broto hepático dos embriões e fetos demonstraram morfologia celular fusiforme do tipo fibroblast like, representado nas figuras 9 e 10 nos diferentes períodos analisados. As células isoladas apresentaram morfologia fibroblastóide, com núcleo delimitado, com 2 ou 3 nucléolos evidentes e citoplasma com limites imprecisos. Apresentaram formação de monocamada ou "tapete celular" após atingirem a alta confluência, como demonstrado pela foto 8B.
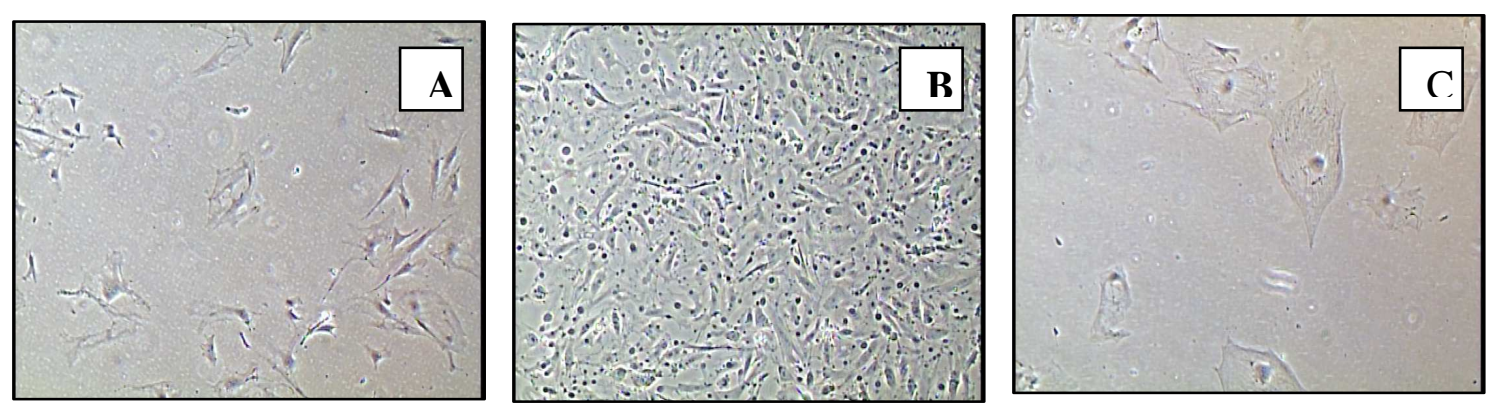

Figura 9 - Fotomicrografias obtidos em microscópio invertido representativas das células do broto hepático de ratos Fischer 344, onde A: $\mathrm{CBH}$ 12,5, B e C: CBH 14,5 e CBH 16,5 dias de gestação. Aumento de $20 \mathrm{x}$ 

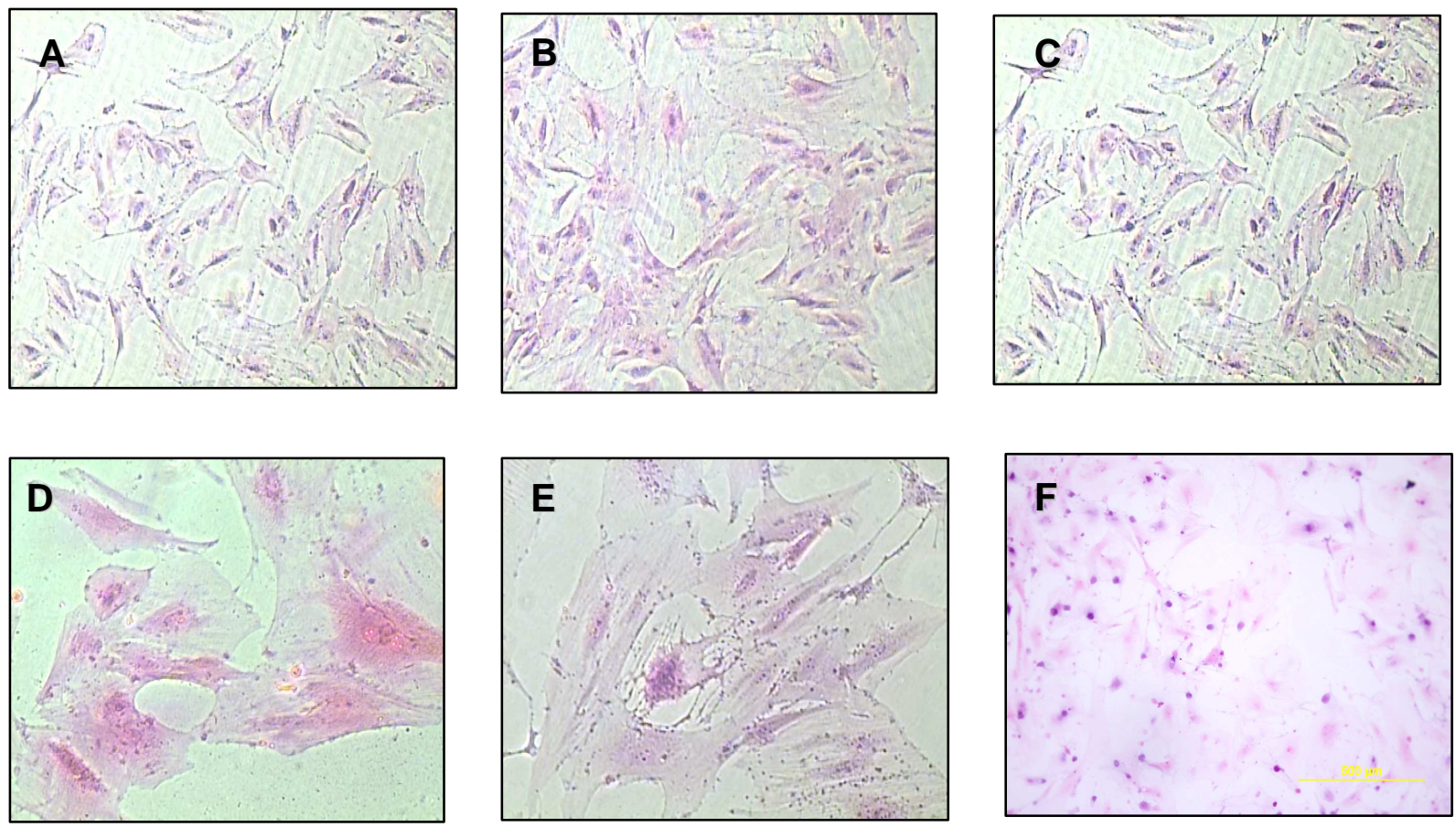

Figura 10 - Fotomicrografias obtida em microscópico invertido evidenciando a morfologia das células do broto hepático dos embriões e dos fetos de ratos em seus diferentes dias de gestação. A e $\mathrm{D}$ ( $\mathrm{CBH} 12,5$ dias), $\mathrm{B}$ e E (CBH 14,5dias) e C e F (CBH 16,5 dias). 40x.Coloração Hematoxilina-eosina (HE)

\subsubsection{Microscopia Eletrônica de Varredura}

As células utilizadas para analise na microscopia eletrônica de varredura foram nos 3 períodos gestacionais estudado e na 5 passagem. As amostras das $\mathrm{CBH}$ no período de 12,5 dias evidenciando células aderidas a superfície da placa de cultura, fusiformes e com células em divisão celular. (Figura 11).

No período de 14,5 dias as $\mathrm{CBH}$ apresentavam-se em maior densidade, com numerosas células com brotamentos e em divisão celular, como também se observa a síntese e organização da matriz extracelular.

As $\mathrm{CBH}$ de 16,5 dias apresentaram-se firmemente aderidas a superfície da placa de cultura com organização e maturação das fibras da Matriz Extracelular, que possibilitam a evidenciação das interações, conexões e funções entre as células 
recém proliferadas. $O$ aspecto geral demonstra células com maior grau de maturação e diferenciação celular (Figura 12).
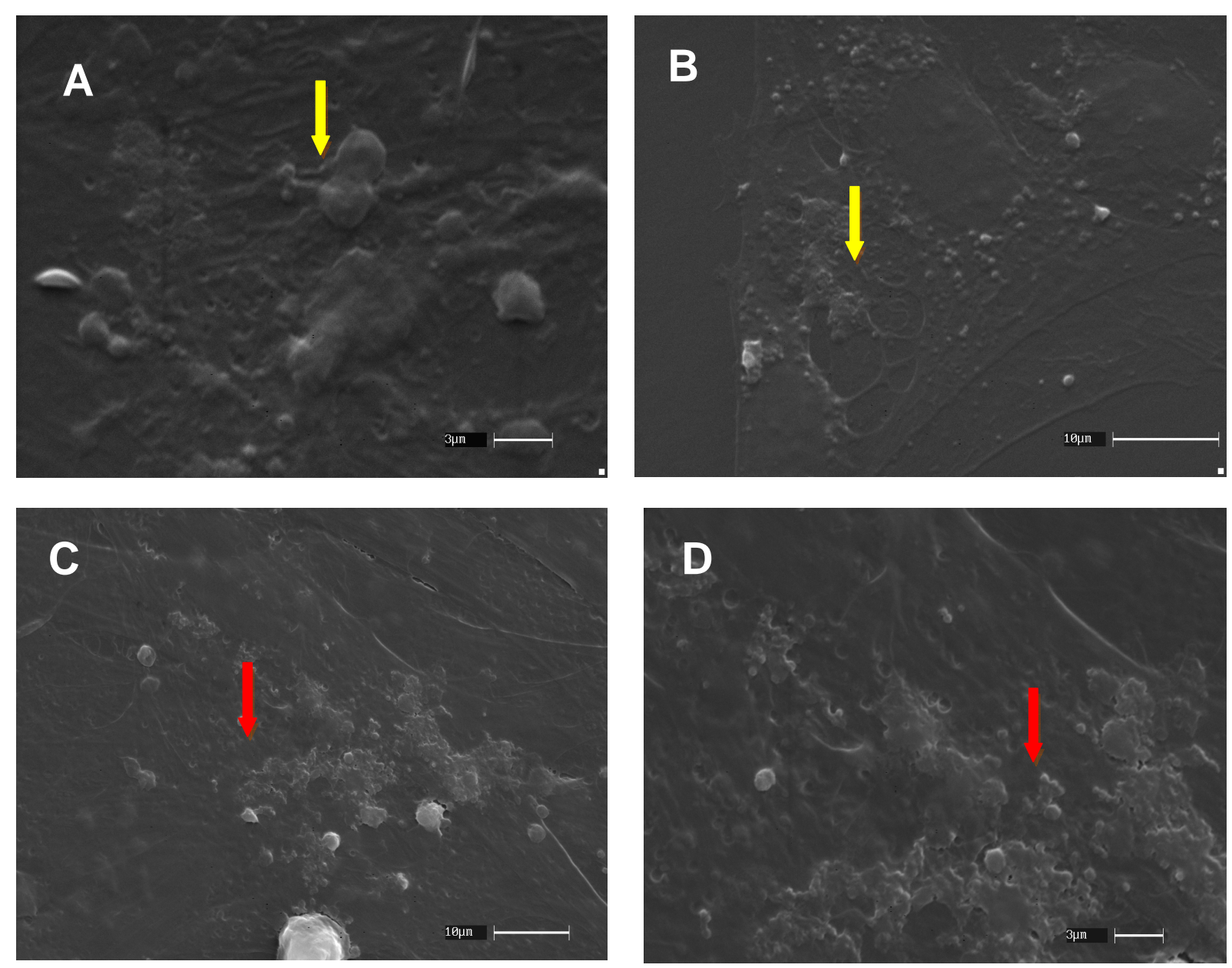

Figura 11- Fotomicrografia de microscopia eletrônica de varredura das células do broto hepático de ratos da linhagem Fischer 344, nos períodos 12,5 dias (figura $A$ e $B$ ) setas amarela e 14,5dias (figura $C$ e D) setas vermelhas. Aumento A e D 3um; C e D $10 \mu \mathrm{m}$ 

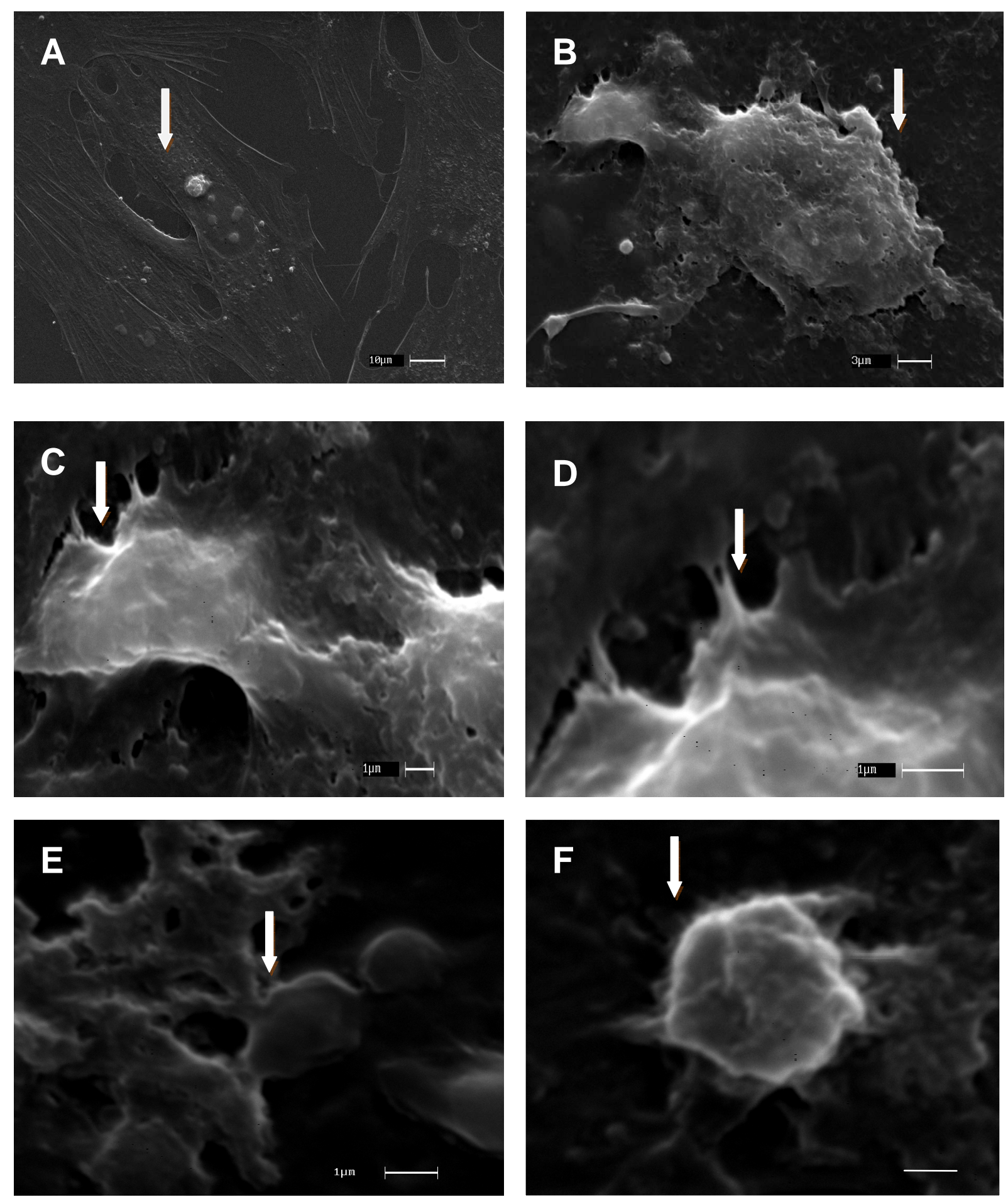

Figura 12 - Fotomicrografia da microscopia eletrônica de varredura das células do broto hepático de ratos no período de 16,5 dias (setas brancas). Notase detalhes da organização da monocamada de células e fibras da matriz extracelular. Aumento de A $10 \mu \mathrm{m}$; B e F $3 \mu \mathrm{m}$; C, D e E $1 \mu \mathrm{m}$ 


\subsection{Análise Bioquímica}

Os resultados da análise bioquímica (TGO e TGP) estão descritos abaixo:

\subsubsection{Transaminase Glutâmico Oxalacética (TGO)}

As determinações das enzimas hepáticas foram realizadas nas culturas de células de broto hepático nos diferentes dias de gestação, CBH12,5 , CBH14,5 e $\mathrm{CBH} 16,5$. Todos os resultados foram corrigidos pela concentração de proteína total obtida pelo método Bradford, utilizando-se como curva padrão soro albumina bovina (BSA), das culturas celulares dos brotos hepáticos rompidos mecanicamente em nitrogênio líquido.

Os valores expressos em $\mathrm{mg} / \mathrm{mL}$ representam a média e desvio padrão de 6 amostras diferentes correspondente a cada período embrionário. Sendo, que as unidades obtidas para alamino amino transferase ALT e aspartato amino transferase AST foi de U/L.

Os resultados mostraram que a concentração de TGO e TGP foram significativamente menores quantidades no período de 12,5 dias quando comparadas os dois períodos, os valores estão representados nas tabelas 1 e 2 e gráficos 2 e 3. 
Tabela 1 - Valores de média de expressão TGO de células do broto hepático de diferentes períodos de cultura em comparação ao hepatócito normal.

\begin{tabular}{|c|c|c|c|c|}
\hline \multicolumn{3}{|c|}{$\begin{array}{l}\text { Dias de obtenção das células do } \\
\text { broto hepático }(n=06)\end{array}$} & \multicolumn{2}{|c|}{$\begin{array}{l}\text { Concentração de TGO } \\
\overline{\mathbf{x}} \pm \mathbf{D P}\end{array}$} \\
\hline \multicolumn{3}{|c|}{$\mathrm{CBH} 12,5$} & \multicolumn{2}{|c|}{$21,6 \pm 2,1$} \\
\hline \multicolumn{3}{|c|}{$\mathrm{CBH} 14,5$} & \multicolumn{2}{|c|}{$53,4 \pm 2,2$ ** } \\
\hline \multicolumn{3}{|c|}{$\mathrm{CBH} 16,5$} & \multicolumn{2}{|c|}{$54,3 \pm 3,3^{* *}$} \\
\hline \multicolumn{3}{|c|}{ Hepatócito normal } & \multicolumn{2}{|c|}{$27,2 \pm 3,2$} \\
\hline \multicolumn{5}{|c|}{$\begin{array}{l}\bar{x}=\text { Média } \\
\text { DP = Desvio Padrão; } \\
\mathrm{n}=\text { Número de amostras analisadas }\end{array}$} \\
\hline $\begin{array}{r}70 \\
60 \\
50 \\
40 \\
\frac{1}{3} \\
30 \\
20 \\
10 \\
0\end{array}$ & \#泮 & 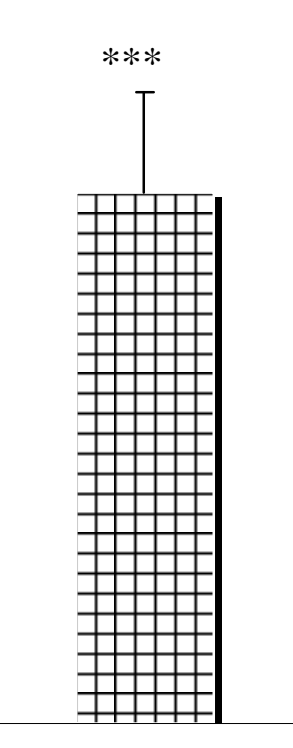 & \#斐 & \#册 \\
\hline & $\mathrm{CBH} 12,5$ dias & $\mathrm{CBH} 14,5$ dias & $\mathrm{CBH} 16,5$ dias & Hepatócito normal \\
\hline
\end{tabular}

Gráfico 2 - Gráfico de barras representando os valores de média \pm DP para TGO $(\mathrm{U} / \mathrm{L})$ das $\mathrm{CBH}$ nos diferentes dias de gestação em comparação ao hepatócito de rato normal.

*** Diferenças estatísticas Teste de Variância de Anova entre os grupos de CBH e controle 


\subsubsection{Transaminase Glutâmico Pirúvica (TGP)}

Tabela 2 - Valores de média de expressão TGP (U/L) de CBH nos diferentes períodos de gestação em comparação ao hepatócito normal

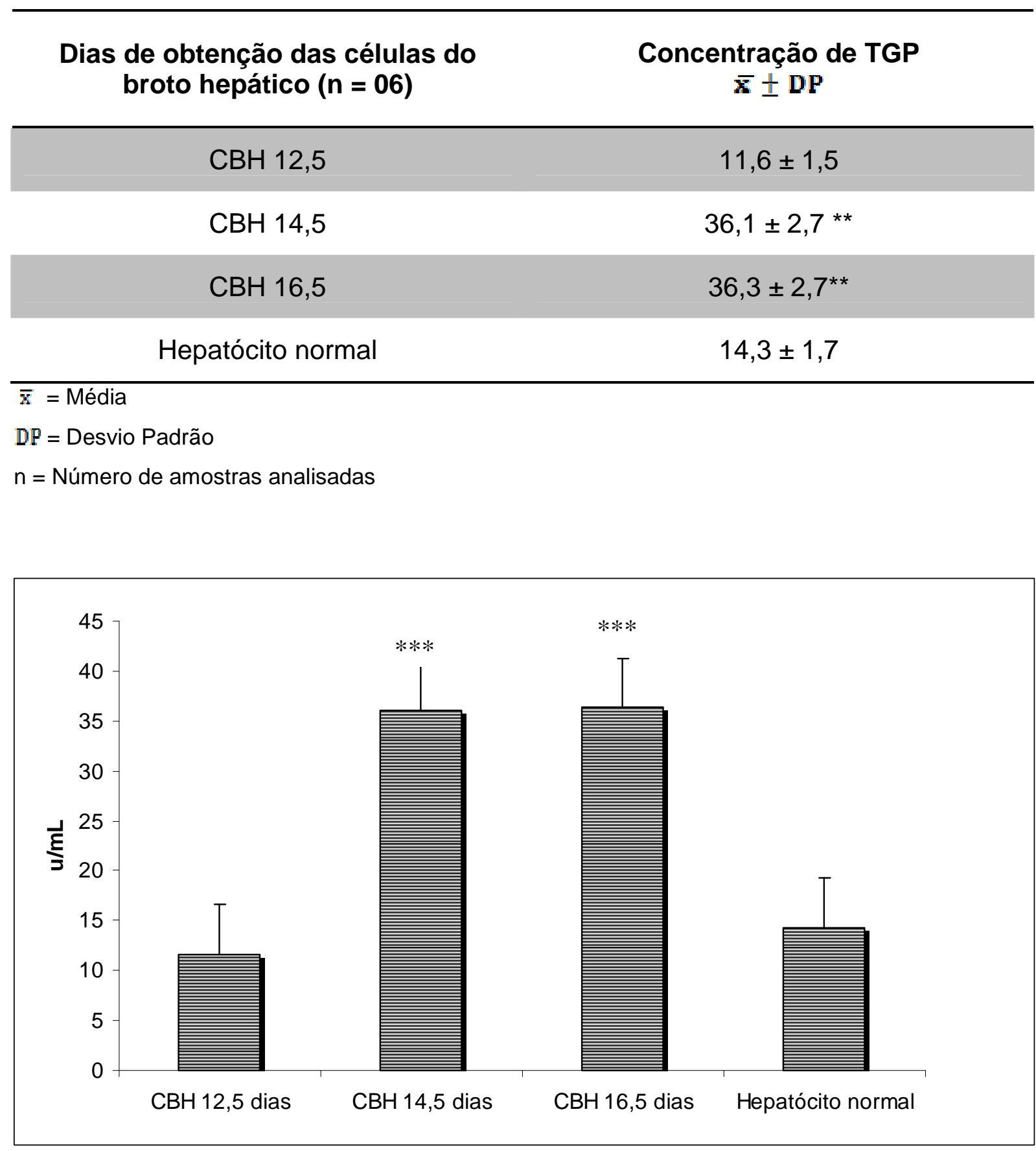

Gráfico 3 - Gráfico de barras representando os valores de média $\pm D P$ para os valores de TGP $(\mathrm{U} / \mathrm{L})$ de $\mathrm{CBH}$ nos diferentes dias de gestação em comparação ao hepatócito de rato normal.

*** Diferenças estatísticas Teste de Variância de ANOVA entre os grupos CBH e o grupo controle. 


\subsection{Análises dos marcadores por citometria de fluxo}

A Citometria de fluxo é uma técnica utilizada para contar, examinar e classificar partículas microscópicas suspensas em meio líquido em fluxo. Permite a análise de vários parâmetros simultaneamente, sendo conhecida também por citometria de fluxo multiparamétrica. Através de um aparelho de detecção ópticoeletrônico são possíveis análises de características físicas e/ou químicas de uma simples célula.

Após o crescimento, expansão, congelamento e recultivo das células embrionárias e fetais do broto hepático, foram realizados as análises dos marcadores por citometria de fluxo. Foram utilizadas diferentes amostras de células do broto hepático, sendo em média analisadas as células após a $4 \square$ e 5 passagem de cultura.

\subsubsection{Marcadores de Células Mesenquimais - células-tronco}

A expressão dos marcadores CD90 mostraram-se aumentados em todos os períodos mantidas em cultura até a $5 \square$ passagem, conforme mostra a tabela 3 e figura 11. O marcador NANOG mostrou-se diferencialmente expresso no período de $\mathrm{CBH}$ 14,5 dias até CBH16, 5 dias em comparação aos demais períodos. Por outro lado, o marcador OCT3/4 mostrou aumentado significativamente no período de 16,5 dias. Enquanto que o marcador STRO1 não se mostrou diferencialmente expresso em nenhum período analisado. Os dados dos valores médios \pm DP estão apresentados na tabela 3 e gráfico 4. Os histogramas representativos adquiridos pelo citômetro pelo programa Cell Quest e analisados pelo programa WInMdi.2.8 (Gráfico 5). 
Tabela 3- Valores de média de expressão dos marcadores de células-tronco mesenquimais obtido por citometria de fluxo em $\mathrm{CBH}$ de diferentes períodos de gestação

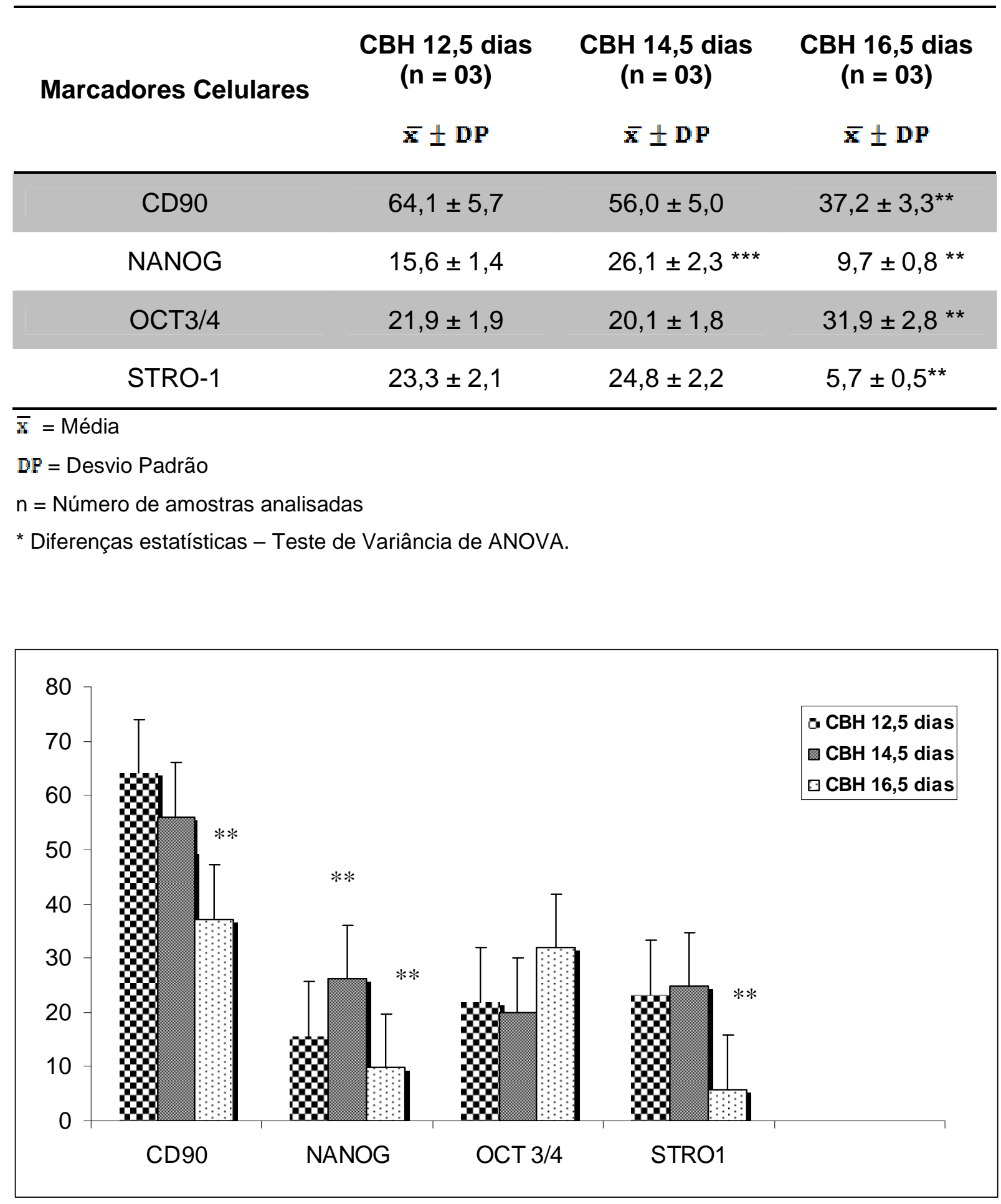

Gráfico 4 - Gráfico de barras representando os valores de média \pm DP para os marcadores de células mesenquimais expressos em células do broto hepático nos diferentes dias de gestação obtidos por citometria de fluxo 


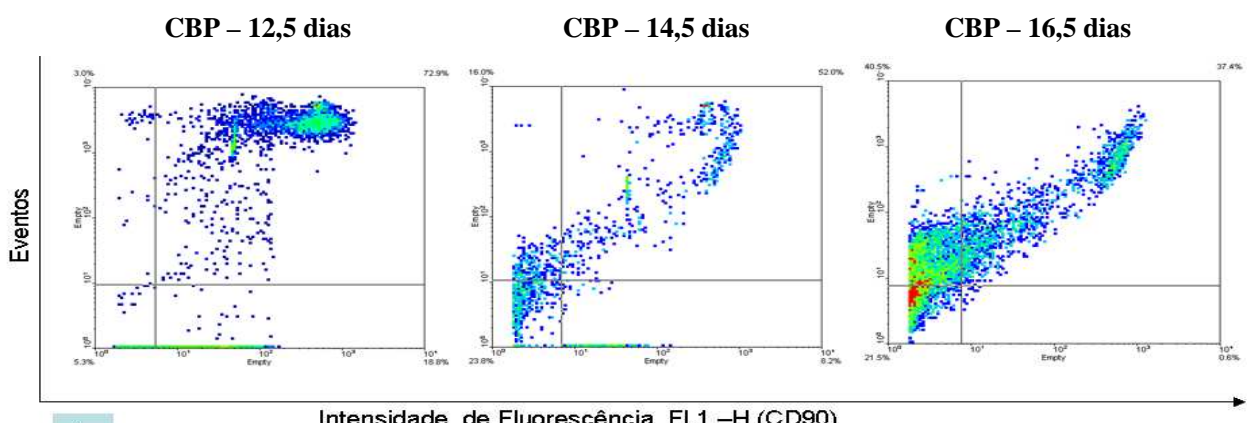

A Intensidade de Fluorescência FL1 -H (CD90)

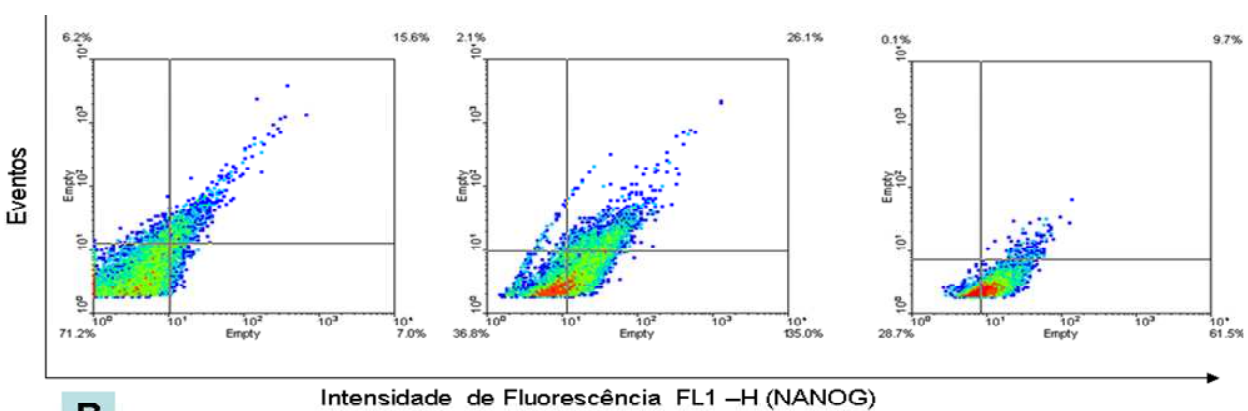

B Intensidade de Fluorescência FL1 -H (NANOG)

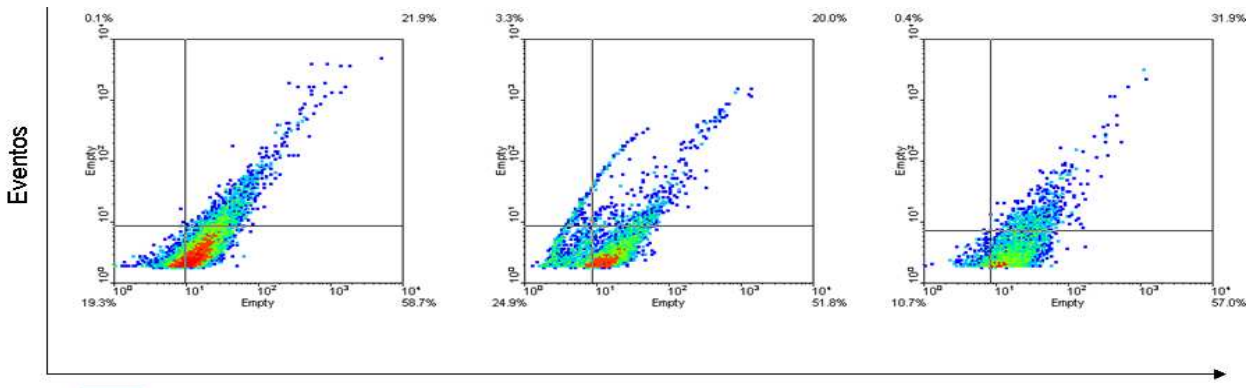

C Intensidade de Fluorescência FL1 - H (OCT3/4)

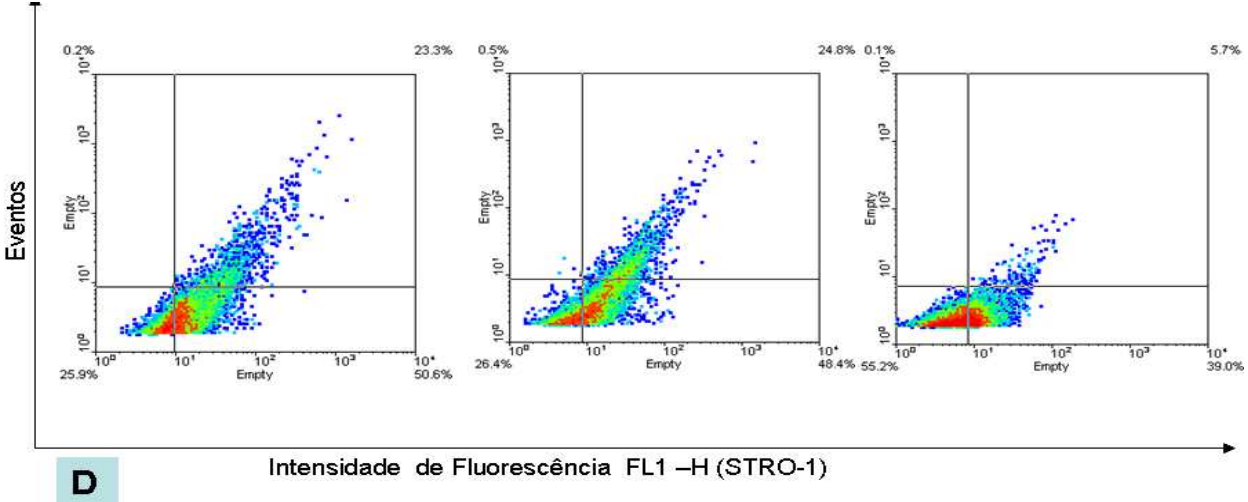

Gráfico 5 - Gráficos dot plot representativo obtido por citometria de fluxo para os marcadores mesenquimais CD90 (A), NANOG (B), OCT3/4 (C) e STRO1 (D), em células do broto hepático de ratos Fischer 344 nos períodos 12,5; 14,5 e 16,5 dias. Adquiridas pelo programa CellQuestPro e analisado no programa WinMDI2.9 


\subsubsection{Marcadores de Citoesqueleto}

Foram analisados por citometria de fluxo os seguintes marcadores do citoesqueleto CK-8, CK-18 e Desmina, em CBH dos períodos 12,5; 14,5 e 16,5 dias até a $5 \square$ passagem. A expressão dos marcadores CK-8, CK-18 e desmina foram significativamente diminuídas nos períodos 12,5 em relação aos demais períodos. Os dados dos valores médios \pm DP estão apresentados na tabela 4 e gráfico 6 . Os histogramas representativos adquiridos pelo citômetro pelo programa Cell Quest e analisados pelo programa WInMdi.2.8 (Gráfico 7).

Tabela 4 - Valores de média de expressão dos marcadores de citoesqueleto obtido por citometria de fluxo em CBH de diferentes períodos de gestação

\begin{tabular}{cccc}
\hline Marcadores Celulares & $\begin{array}{c}\text { CBH 12,5 dias } \\
(\mathbf{n}=\mathbf{3})\end{array}$ & $\begin{array}{c}\text { CBH 14,5 dias } \\
(\mathbf{n}=\mathbf{3})\end{array}$ & $\begin{array}{c}\text { CBH 16,5 dias } \\
(\mathbf{n}=\mathbf{3})\end{array}$ \\
\hline CK-8 & $\overline{\mathbf{x}} \pm \mathbf{D P}$ & $\overline{\mathbf{x}} \pm \mathbf{D P}$ & $\overline{\mathbf{x}} \pm \mathbf{D P}$ \\
CK-18 & $83,6 \pm 7,6$ & $59,8 \pm 5,3$ & $51,9 \pm 4,6^{* * *}$ \\
DESMINA & $81,3 \pm 7,7$ & $52,1 \pm 4,7$ & $45,2 \pm 4,1^{* * *}$ \\
\hline$\overline{\mathbf{x}}=$ Média & $79,1 \pm 7,3$ & $58,2 \pm 5,2$ & $39,8 \pm 3,6^{* * *}$ \\
$\begin{array}{l}\text { DP = Desvio Padrão } \\
\mathrm{n}=\text { Número de amostras analisadas } \\
\text { * Diferenças estatísticas - Teste de Variância de ANOVA. }\end{array}$ & & \\
\hline
\end{tabular}




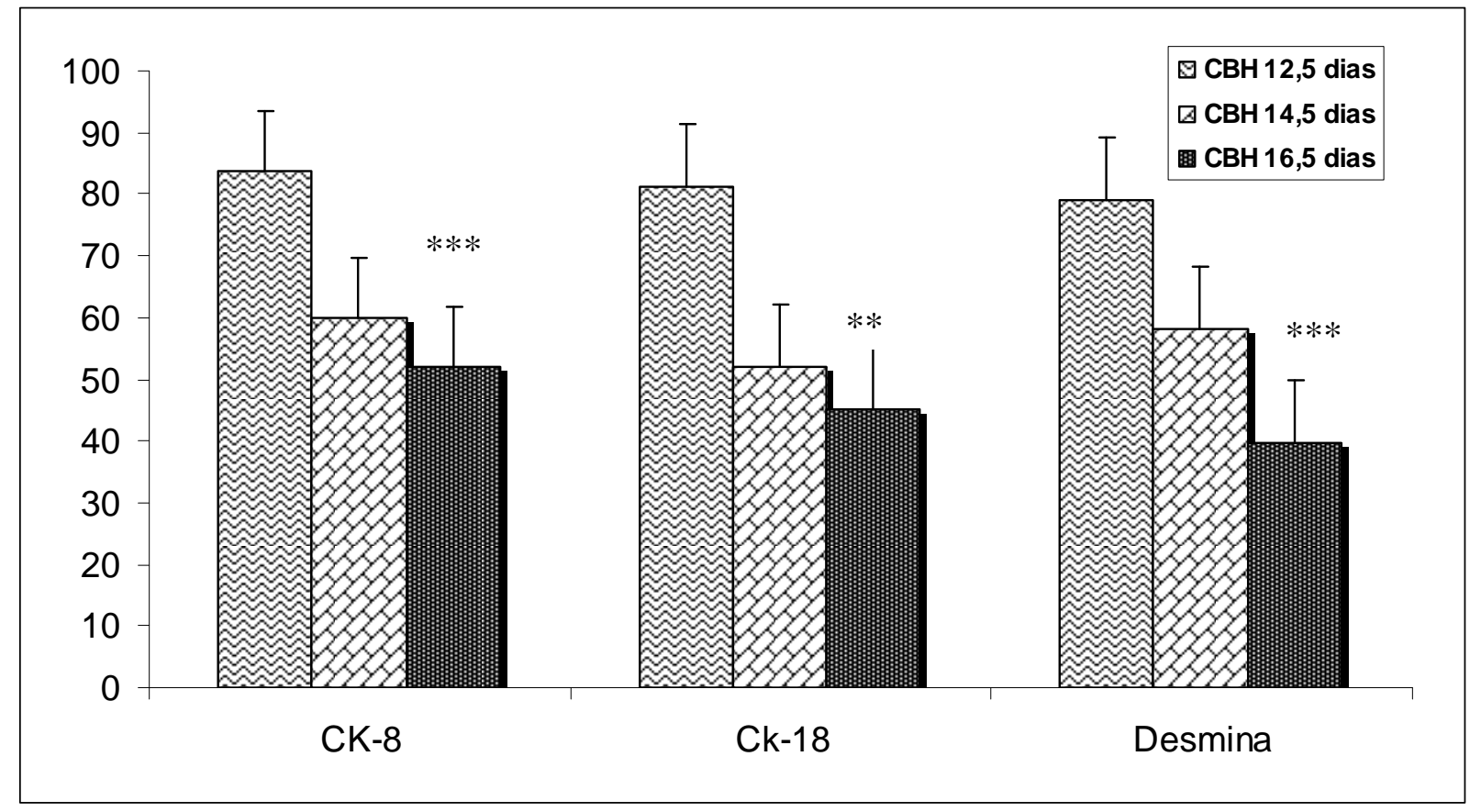

Gráfico 6- Gráfico de barras representando os valores de média \pm DP para os marcadores de citoesqueleto expressos em células do broto hepático nos diferentes dias de gestação obtidos por citometria de fluxo 

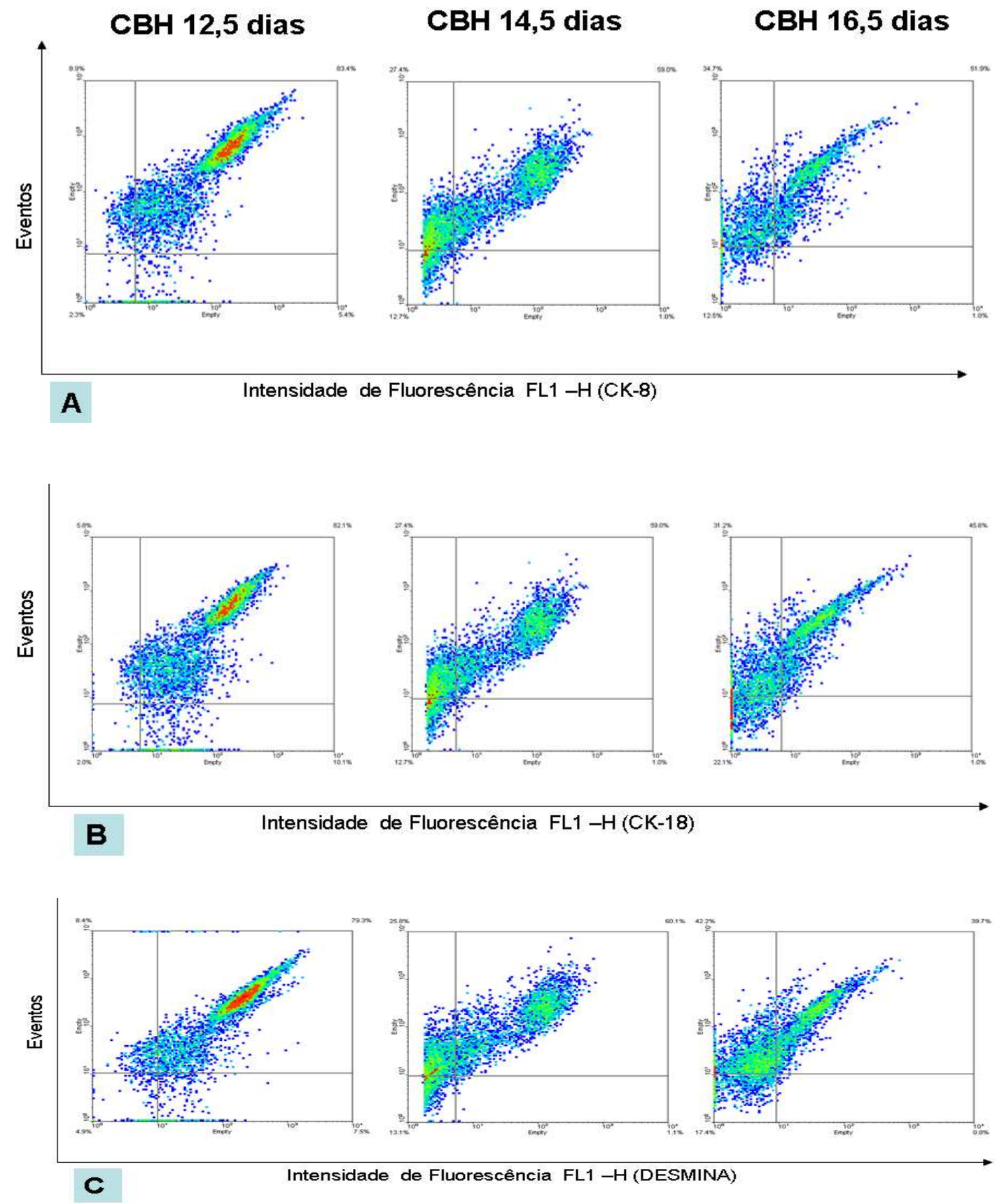

Gráfico 7 - Gráficos dot plot representativo obtido por citometria de fluxo para os marcadores de citoesqueleto CK-8 (A), CK-18 (B) e Desmina (C), em células do broto hepático de ratos Fischer 344 nos períodos 12,5; 14,5 e 16,5 dias. Adquiridas pelo programa CellQuestPro e analisado no programa WinMDI 2.9 


\subsubsection{Reguladores do Ciclo Celular}

A expressão das proteínas P21, P27 e P53 funcionam como supressores da progressão do ciclo celular. A expressão da P21 esta sobre o controle da P53 enquanto que a P27 ao ser expressa suprime o crescimento celular, provocando desta forma a parada do ciclo celular no ponto de restrição G1-S. Os resultados obtidos mostraram baixa expressão na P53, expressão invariável da P21 e aumento da expressão da P27 significativamente no período de 16,5 dias. O significado biológico deste resultado demonstra supostamente, que a diferenciação das células embrionárias e fetais do broto hepático restringe a parada do ciclo celular da expressão da P53. A expressão da Ciclina D1 é essencial a progressão das células através da fase $\mathrm{G} 1$ do ciclo celular. Sua expressão foi invariável nos três períodos analisados $\mathrm{CBH} 12,5$; $\mathrm{CBH} 14,5$ e $\mathrm{CBH} 16,5$ dias. Os dados dos valores médios $\pm \mathrm{DP}$ estão apresentados na tabela 5 e gráfico 8. Os histogramas representativos adquiridos pelo citômetro pelo programa Cell Quest e analisados pelo programa WInMdi.2.8 (Gráfico 9).

Tabela 5 - Valores de média de expressão dos marcadores de ciclo celular obtidos por citometria de fluxo de $\mathrm{CBH}$ de diferentes períodos de gestação

\begin{tabular}{|c|c|c|c|}
\hline \multirow{2}{*}{ Marcadores Celulares } & $\begin{array}{c}\text { CBH } 12,5 \text { dias } \\
(n=03)\end{array}$ & $\begin{array}{c}\text { CBH } 14,5 \text { dias } \\
(n=03)\end{array}$ & $\begin{array}{c}\text { CBH } 16,5 \text { dias } \\
(n=03)\end{array}$ \\
\hline & $\overline{\mathbf{x}} \pm \mathbf{D P}$ & $\overline{\mathbf{x}} \pm \mathbf{D P}$ & $\overline{\mathbf{x}} \pm \mathbf{D P}$ \\
\hline P53 & $5,7 \pm 0,5$ & $11,8 \pm 1,1$ & $9,8 \pm 0,8$ \\
\hline $\mathrm{P} 21$ & $26,3 \pm 2,3$ & $19,6 \pm 1,5$ & $27,4 \pm 2,4$ \\
\hline $\mathrm{P} 27$ & $11,7 \pm 1,1$ & $15,0 \pm 1,3$ & $29,0 \pm 2,6^{* * *}$ \\
\hline CICLINA D1 & $42,9 \pm 7,9$ & $43,7 \pm 3,9$ & $46,8 \pm 4,2$ \\
\hline \multicolumn{4}{|l|}{$\overline{\bar{x}}=$ Média } \\
\hline \multicolumn{4}{|l|}{$\mathrm{DP}=$ Desvio Padrão } \\
\hline \multicolumn{4}{|c|}{$\mathrm{n}=$ Número de amostras analisadas } \\
\hline Ças & & & \\
\hline
\end{tabular}




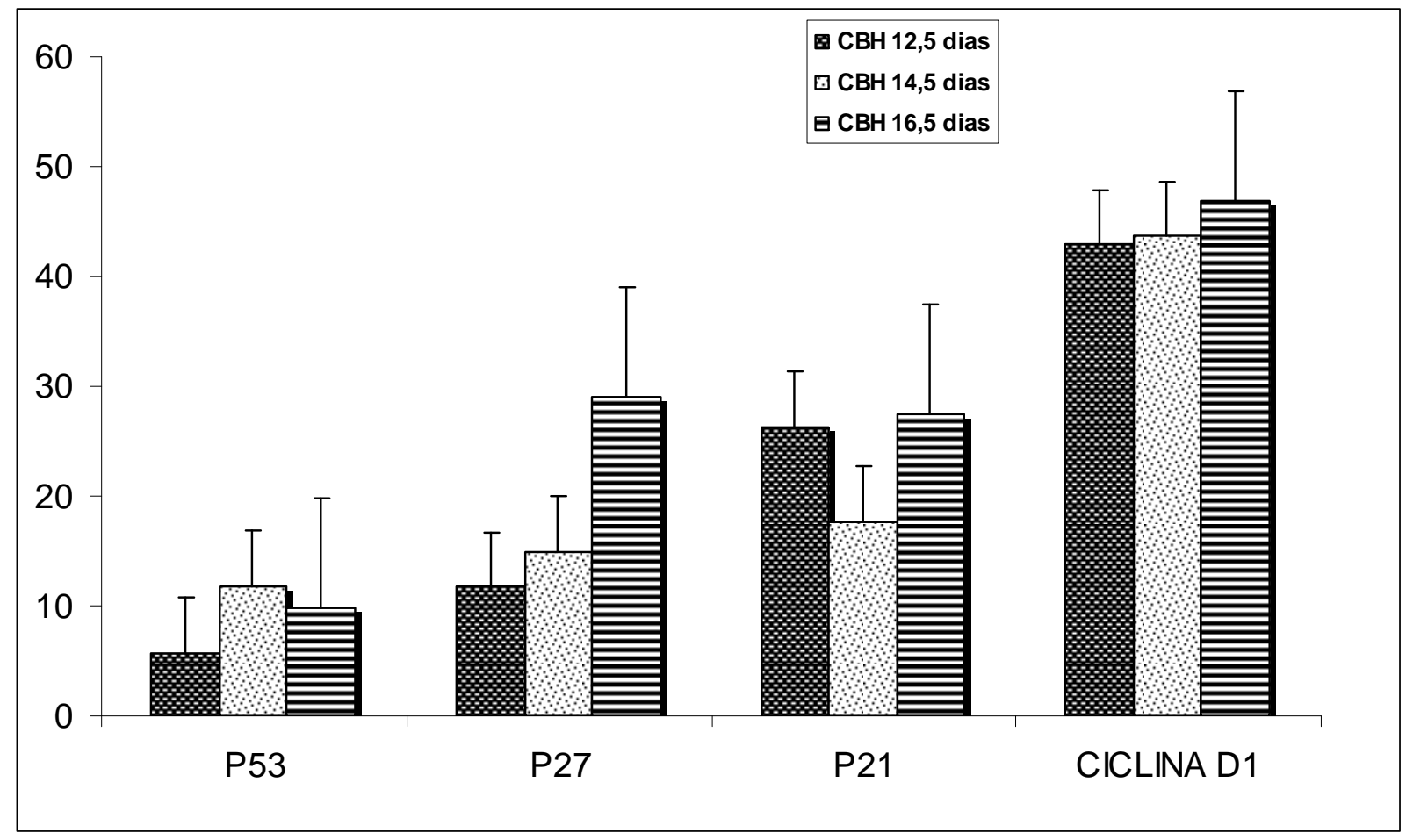

Gráfico 8 - Gráfico de barras representando os valores de média \pm DP para os reguladores de progressão do ciclo celular expressos em células do broto hepático nos diferentes dias de gestação obtidos por citometria de fluxo 


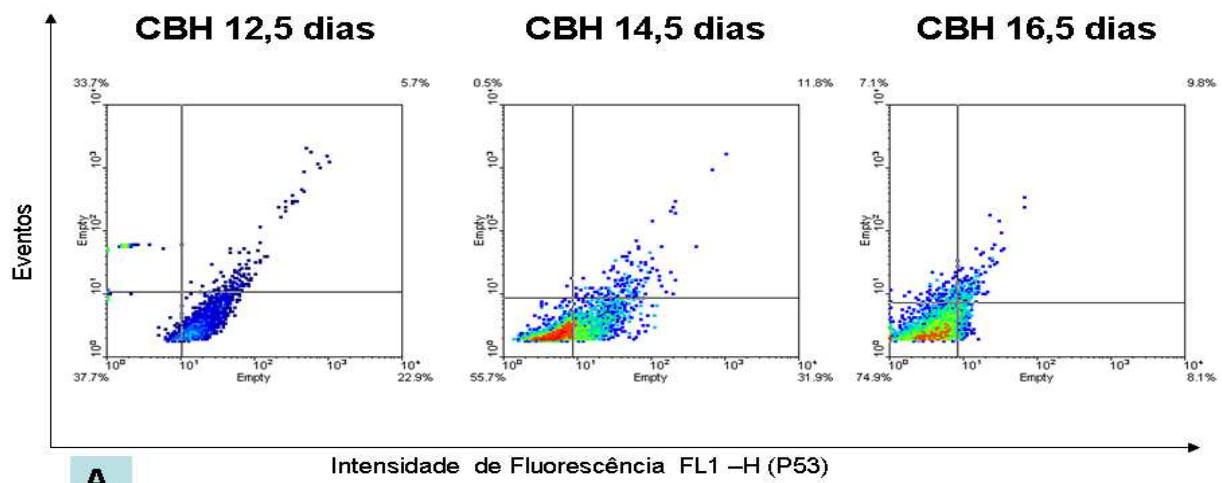

A
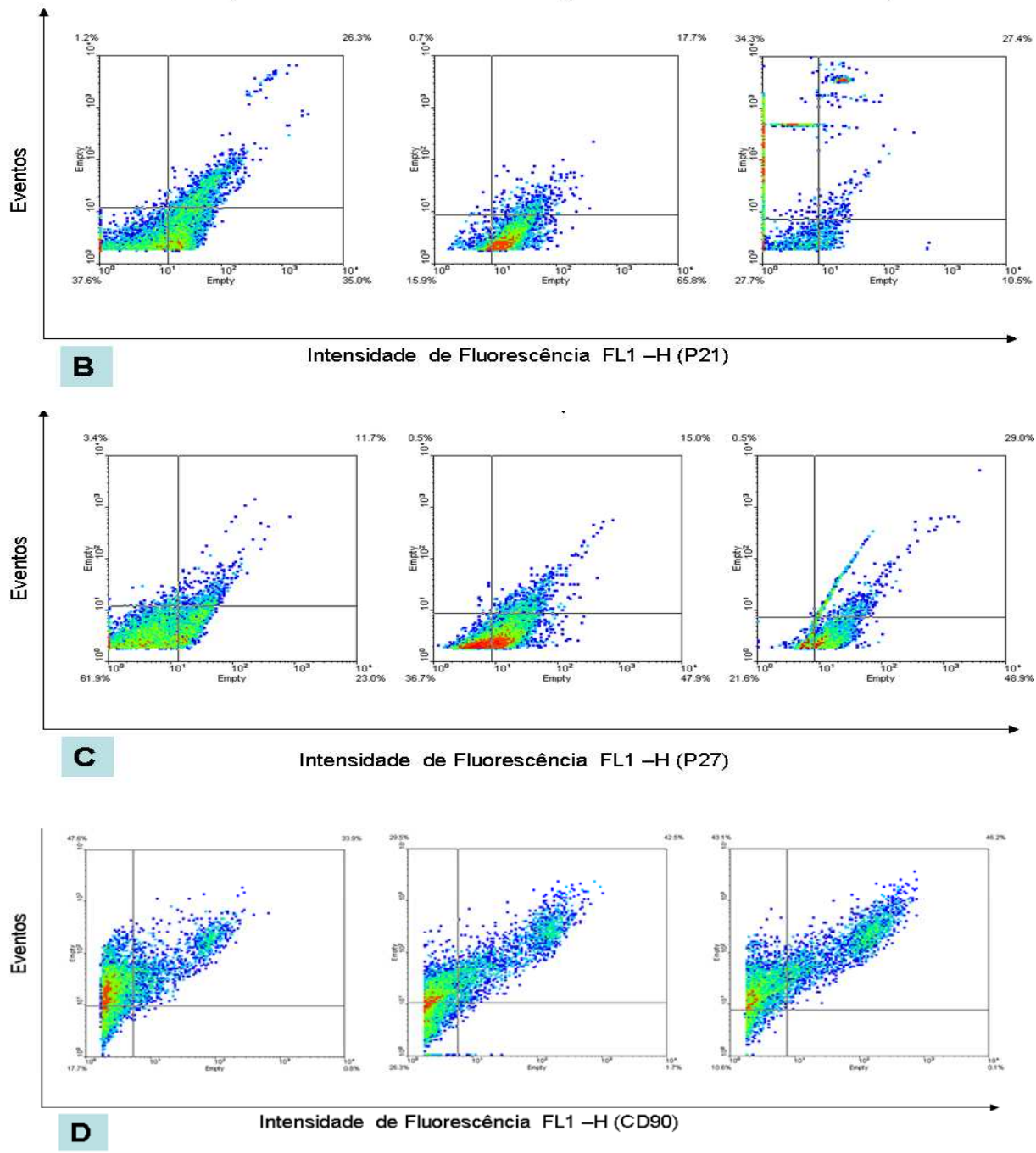

Gráfico 9 - Gráficos dot plot representativo obtido por citometria de fluxo para os marcadores de ciclo celular P53 (A), P21 (B), P27 (C) e Ciclina D1 (D), em células do broto hepático de ratos Fischer 344 nos períodos 12,5; 14,5 e 16,5 dias. Adquiridas pelo programa CellQuestPro e analisado no programa WinMDI 2.9 


\subsubsection{Marcadores de Vias de Morte Celular}

A determinação da quantidade de células mortas por apoptose ou necrose, foi determinada pela expressão dos marcadores Anexina V / PI e as vias de apoptose pela expressão das proteínas pró e anti apoptóticas Bax, Bad, Bcl-2 e das cisteíno protease Caspase-3 fosforilada, em células do broto hepático de ratos Fischer mantidas em cultura até a $5 \square$ passagem.

Nossos resultados mostraram que as células do broto hepático não expressaram significativamente nenhuma dessas proteínas pró apoptóticas bem como, as fosfadilcerina.

A expressão da caspase sinaliza a apoptose, pois cliva substratos com resíduos de aspartato. A caspase-3 é uma caspase executora e os resultados obtidos em células do broto hepático de ratos mostraram que não houve alteração significativa em sua expressão.

Os dados dos valores médios \pm DP estão apresentados na tabela 6 e gráfico 10. Os histogramas representativos adquiridos pelo citômetro pelo programa Cell Quest e analisados pelo programa WInMdi.2.9 ( Gráfico 11).

Tabela 6 - Valores de média de expressão dos marcadores de vias de morte celular programada em células obtidas por citometria de fluxo de $\mathrm{CBH}$ de diferentes períodos de gestação

\begin{tabular}{cccc}
\hline Marcadores Celulares & $\begin{array}{c}\text { CBH 12,5 dias } \\
(\mathbf{n}=\mathbf{3})\end{array}$ & $\begin{array}{c}\text { CBH 14,5 dias } \\
(\mathbf{n}=\mathbf{3})\end{array}$ & $\begin{array}{c}\text { CBH 16,5 dias } \\
(\mathbf{n}=\mathbf{3})\end{array}$ \\
$\overline{\mathbf{x}} \pm \mathbf{D P}$ & $\overline{\mathbf{x}} \pm \mathbf{D P}$ & $\overline{\mathbf{x}} \pm \mathbf{D P}$ \\
\hline ANEXINA - V (Apoptose) & $13,9 \pm 1,2$ & $5,7 \pm 0,5^{\star *}$ & $6,8 \pm 0,6^{\star *}$ \\
PI (Necrose) & $3,4 \pm 1,3$ & $2,9 \pm 1,2$ & $1,1 \pm 0,7$ \\
CASPASE- 3 & $15,6 \pm 2,9$ & $19,5 \pm 3,5$ & $12,7 \pm 1,1^{*}$ \\
BAX & $23,7 \pm 2,1$ & $25,7 \pm 3,4$ & $24,9 \pm 2,2$ \\
BAD & $23,2 \pm 3,7$ & $23,3 \pm 2,0$ & $22,8 \pm 2,0$ \\
BCL -2 & $39,6 \pm 6,7$ & $43,6 \pm 4,8$ & $33,3 \pm 2,1$ \\
\hline
\end{tabular}


$\overline{\mathrm{x}}=$ Média

DP = Desvio Padrão

$\mathrm{n}=$ Número de amostras analisadas*

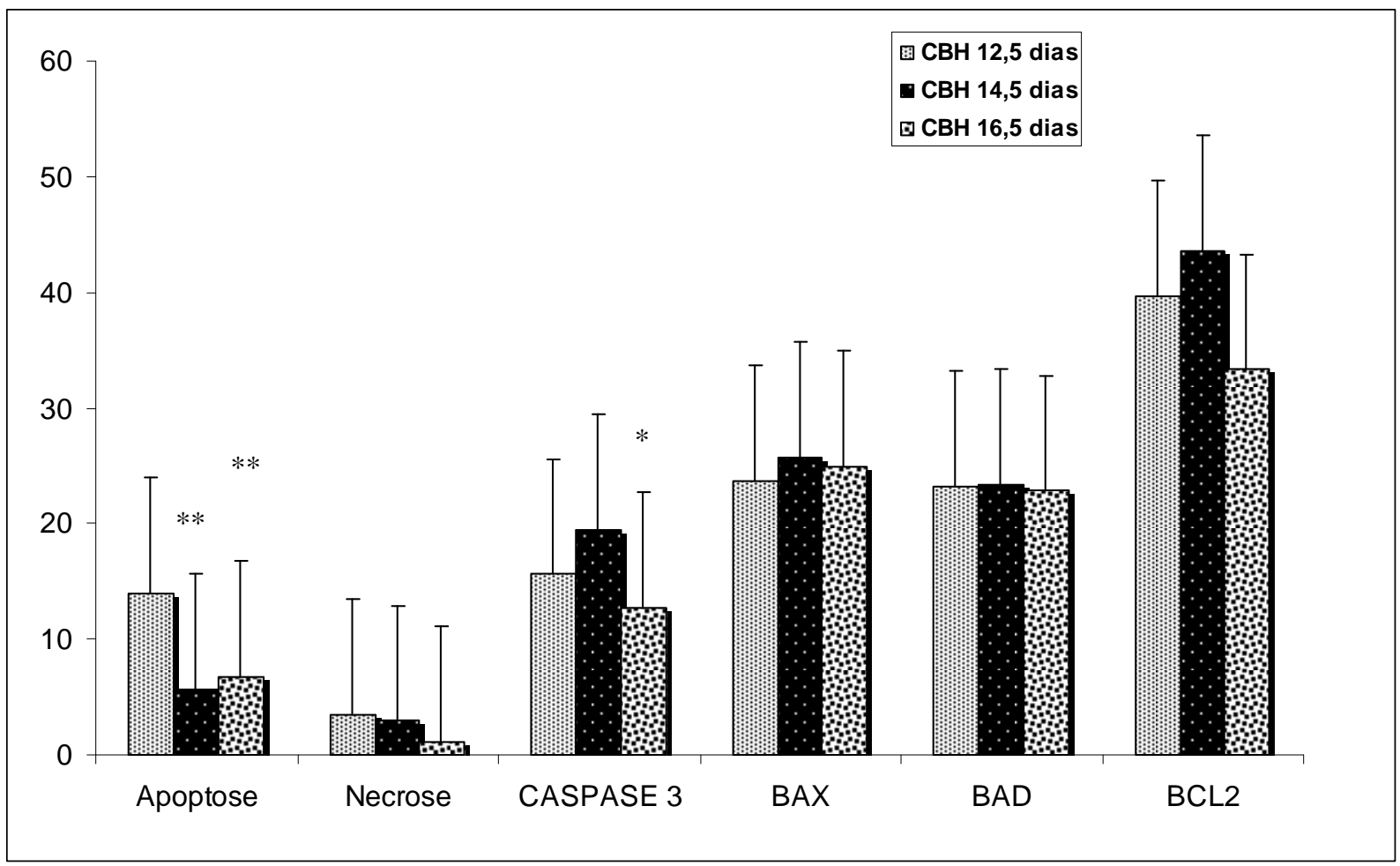

Gráfico 10 - Gráfico de barras representando os valores de média \pm DP para os marcadores de vias de morte celular programada (apoptose) e necrose, expressos em células do broto hepático de ratos Fischer 344 nos diferentes dias de gestação obtidos por citometria de fluxo

* Diferenças estatísticas entre os diferentes períodos de gestação - Teste de Variância ANOVA 

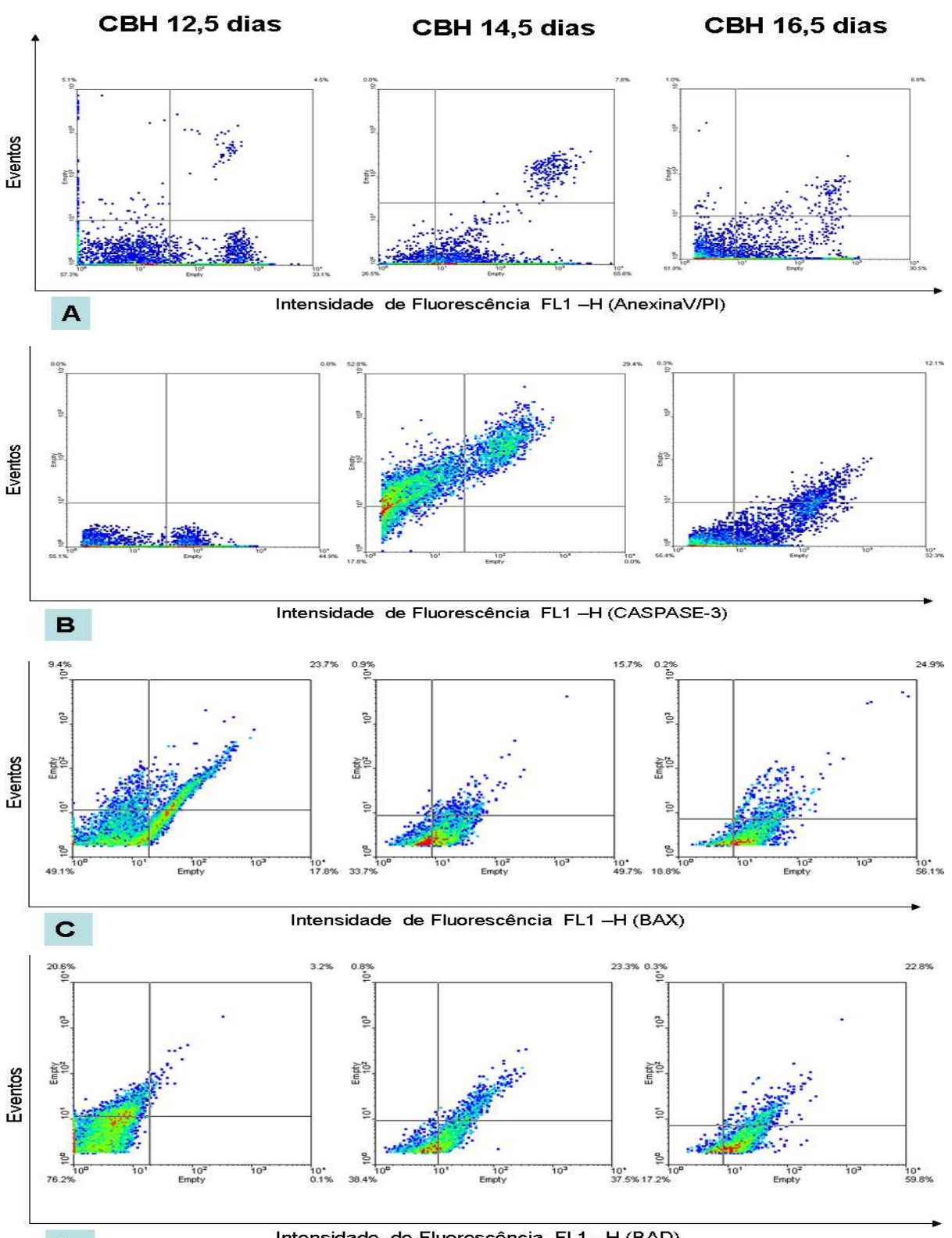

D Intensidade de Fluorescência FL1 - H (BAD)

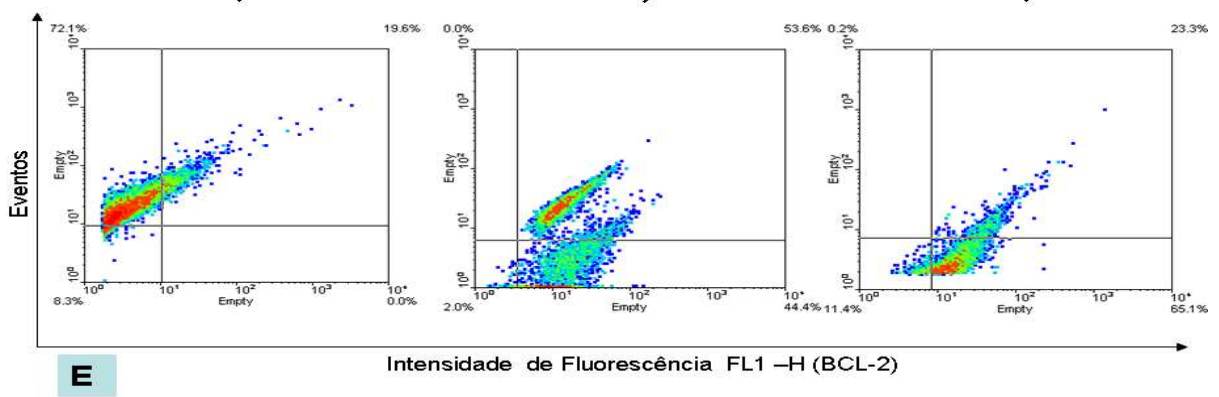

Gráfico 11 - Gráficos dot plot representativo obtido por citometria de fluxo para os marcadores de vias de morte celular Anexina/ PI (A), Caspase-3 (B), BAX (C), BAD (D), BCl-2 (E), em células do broto hepático de ratos Fischer 344 nos períodos 12,5; 14,5 e 16,5 dias. Adquiridas pelo programa CellQuestPro e analisado no programa WinMDI2.9 


\subsubsection{Análise do Potencial Elétrico Mitocondrial}

Este ensaio foi realizado em paralelo ao teste da verificação da proporção de células em apoptose/necrose e a expressão de proteínas de checagem de progressão do ciclo celular. A quantificação do potencial mitocondrial foi realizada no citômetro de fluxo (Becton Dickinson, San Jose, Ca, USA), utilizando-se o programa Cell Quest, versão 3.1, com aquisição de 10.000 eventos, empregando-se uma janela/quadrante definido (gate) de análise a partir dos parâmetros de espalhamento luminoso (volume/ FSC) x (complexidade/ SSC). A partir do gate das células em estudo, foram obtidos histogramas de intensidade de fluorescência no canal FL1-H. Os resultados do teste funcional de fluxo da sonda Rodamina-123 foram analisados na forma de média de intensidade de fluorescência (MIF), na razão entre a MIF da amostra em estudo e do respectivo controle negativo.

Após a aquisição da intensidade de fluorescência arbitrária, emitida pela sonda rodamina 123 e os resultados foram analisadas pelo programa Win MID $2.9 \mathrm{e}$ representados nos histogramas dos diferentes dias de gestação das células $\mathrm{CBH}$ evidenciando as mitocôndrias inativas e ativas, que estão apresentados na tabela 7 e gráfico 12.

Nos períodos de gestação de 14,5 e 16,5 dias observa-se nas CBH o aumento na proporção de células inativas com menor capacidade funcional ou metabólica, quando comparada ao período de 12,5 dias ou mesmo em relação ao hepatócito de rato Fischer normal ( Figura 13). 
Tabela 7 - Valores de média e desvio padrão do potencial elétrico mitocondrial em $\mathrm{CBH}$ nos diferentes períodos de gestação

\begin{tabular}{ccc}
\hline $\begin{array}{c}\text { Dias de obtenção das células } \\
\text { do broto hepático }(\mathbf{n}=\mathbf{0 3})\end{array}$ & $\begin{array}{c}\text { INATIVAS } \\
\overline{\mathbf{x}} \pm \mathbf{D P}\end{array}$ & $\begin{array}{c}\text { ATIVAS } \\
\overline{\mathbf{x}} \pm \mathbf{D P}\end{array}$ \\
\hline CBH 12,5 & $3,86 \pm 1,13$ & $95,54 \pm 9,97$ \\
\hline $\mathrm{CBH} 14,5$ & $22,54 \pm 4,83^{* *}$ & $77,50 \pm 8,82$ \\
\hline CBH 16,5 & $14,35 \pm 1,41^{* *}$ & $85,53 \pm 9,23$ \\
\hline Hepatócitos normais & $5,83 \pm 2,47$ & $94,10 \pm 9,74$ \\
\hline
\end{tabular}

$\overline{\bar{x}}=$ Média

$\mathrm{DP}=$ Desvio Padrão

$\mathrm{n}=$ Número de amostras analisadas

* Diferenças estatísticas - Teste de Variância de ANOVA.

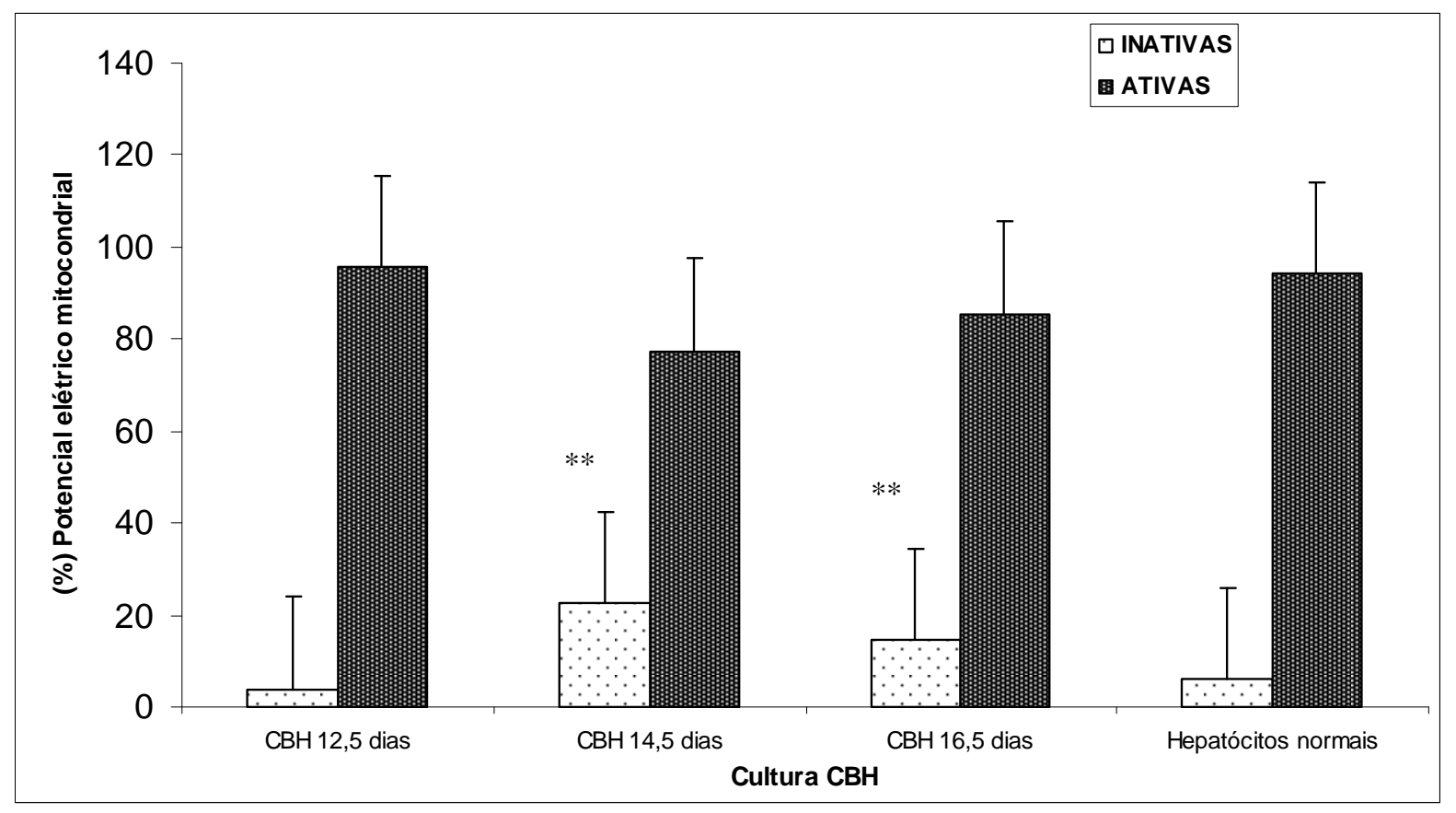

Gráfico 12 - Gráfico de barras representando os valores de média \pm DP do potencial elétrico da mitocôndria das células $\mathrm{CBH}$ nos diferentes períodos de gestação, em comparação ao hepatócito de rato normal 


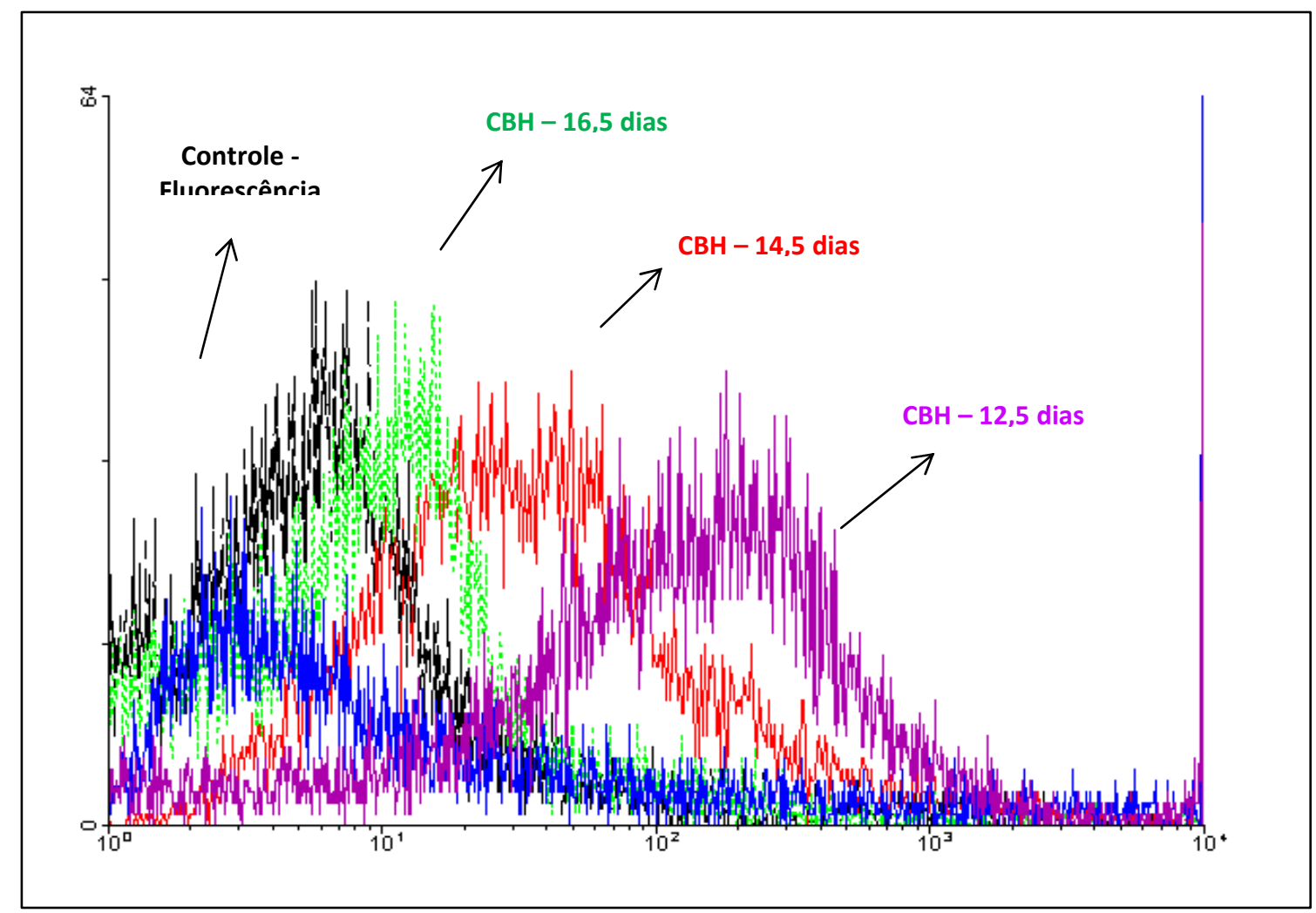

Figura 13- Histograma representativo do potencial elétrico mitocondrial. Curva preto - controle de fluorescência ; curva verde - $\mathrm{CBH}$ 16,5 dias; curva vermelho- $\mathrm{CBH}$ 14,5 dias ; curva roxa . $\mathrm{CBH} 12,5$ dias

\subsubsection{Análise das Fases do Ciclo Celular}

Foram realizadas análises das diferentes fases do ciclo celular das $\mathrm{CBH}$, da $5^{\circ}$ e $6^{\circ}$ passagem de cultura e do hepatócito de rato no rmal e do conteúdo de DNA por citometria de fluxo. Os resultados mostraram acúmulo na fase $\mathrm{G0} / \mathrm{G} 1$, repercutindo na modulação da capacidade de proliferação e aumento na proporção de células com DNA fragmentado, nas células CBH no período de 16,5 dias em comparação aos demais períodos e ao hepatócito normal. O aumento da fragmentação do DNA em média foi de 3,5 e 2,3 vezes, respectivamente nos períodos de 12,5 e 14,5 dias de gestação. A capacidade de síntese e de divisão celular (G2/M) das $\mathrm{CBH}$ foram mantidas em todos os períodos de gestação.

As correlações estatísticas e os histogramas representativos estão apresentadas nas tabela 8 e gráfico 13, mostraram claramente as modificações nas 
proporções de células com potencial proliferativo inversamente proporcional ao DNA fragmentado, nos diferentes períodos de gestação de células $\mathrm{CBH}$ em comparação ao hepatócito normal. As diferentes proporções entre GO/G1 e o conteúdo de DNA fragmentado e as células com capacidade proliferativa estão apresentadas nos gráficos esquemáticos 14, 15,16 e figura 14 .

Tabela 8 - Valores de média e desvio padrão das diferentes fases do ciclo celular das populações de células do broto hepático de ratos Fischer 344, nos diferentes dias de gestação obtido por citometria de fluxo

\begin{tabular}{ccccc}
\hline $\begin{array}{c}\text { Dias de obtenção } \\
\text { das células-tronco } \\
\text { de broto hepático }\end{array}$ & GO/G1 & Fase S & G2/M & $\begin{array}{c}\text { DNA } \\
\text { fragmentado } \\
\overline{\mathbf{x}} \pm \mathbf{D P}\end{array}$ \\
\hline CBH 12,5 & $45,65 \pm 3,91^{* *}$ & $20,46 \pm 2,61$ & $30,19 \pm 1,73$ & $3,59 \pm 1,22$ ** \\
CBH 14,5 & $44,95 \pm 3,87^{* *}$ & $20,54 \pm 2,68$ & $27,53 \pm 3,02$ & $5,50 \pm 1,35 * *$ \\
CBH 16,5 & $57,72 \pm 4,38^{* *}$ & $20,86 \pm 2,63$ & $17,33 \pm 2,40$ & $12,54 \pm 2,04 * * *$ \\
\hline Hepatócitos normais & $25,92 \pm 3,4$ & $21,11 \pm 1,91$ & $16,34 \pm 1,54$ & $13,16 \pm 1,27$ \\
\hline$\overline{\mathbf{x}}=$ Média & & & \\
DP = Desvio Padrão \\
$\mathrm{n}=$ Número de amostras analisadas \\
* Diferenças estatísticas - Teste de Variância de ANOVA.
\end{tabular}




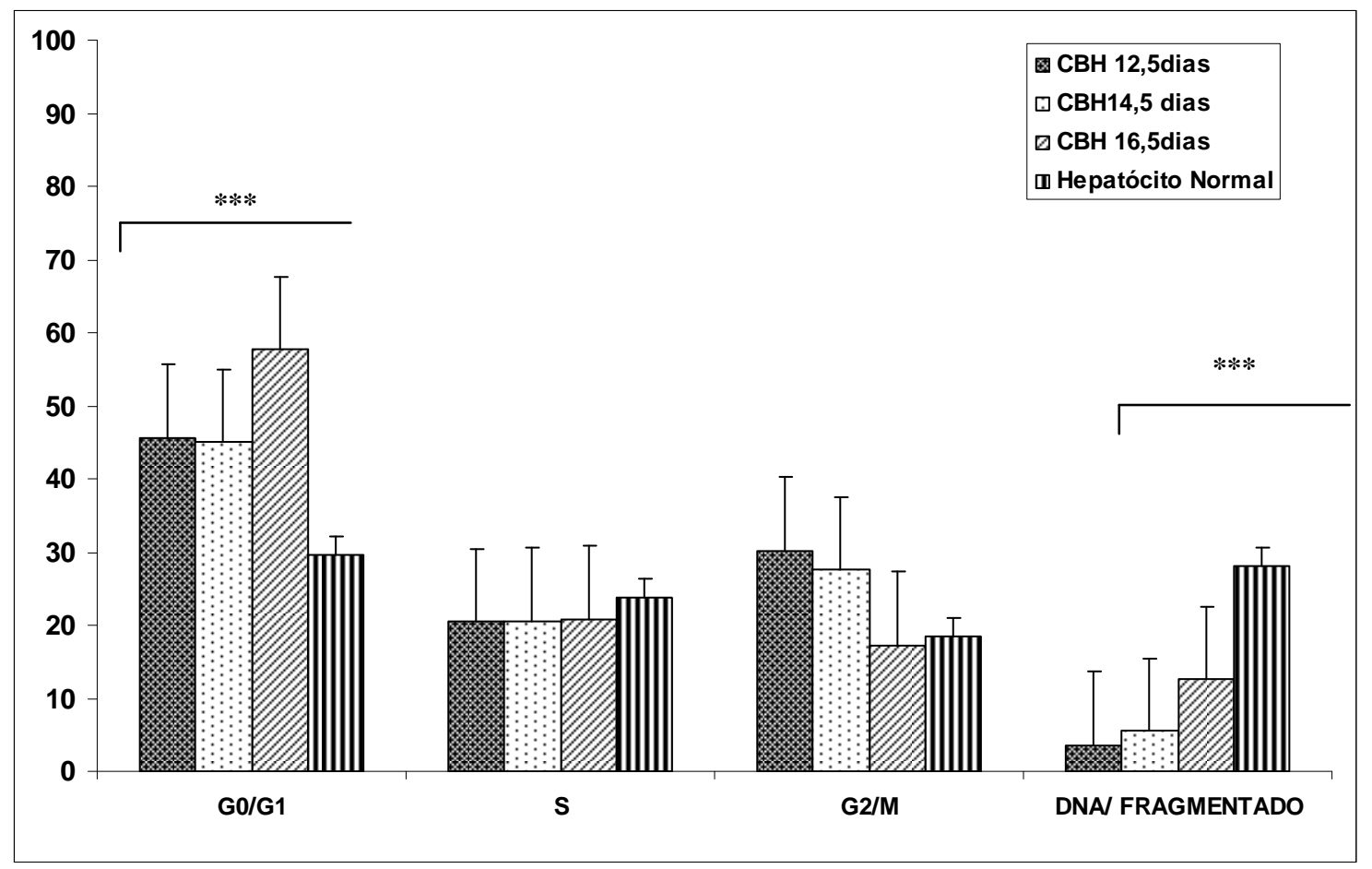

Gráfico 13 - Gráfico de barras representando as médias e desvio padrão das diferentes fases do ciclo celular das populações de células do broto hepático. Observa-se o maior proporção de células na fase de G0/G1

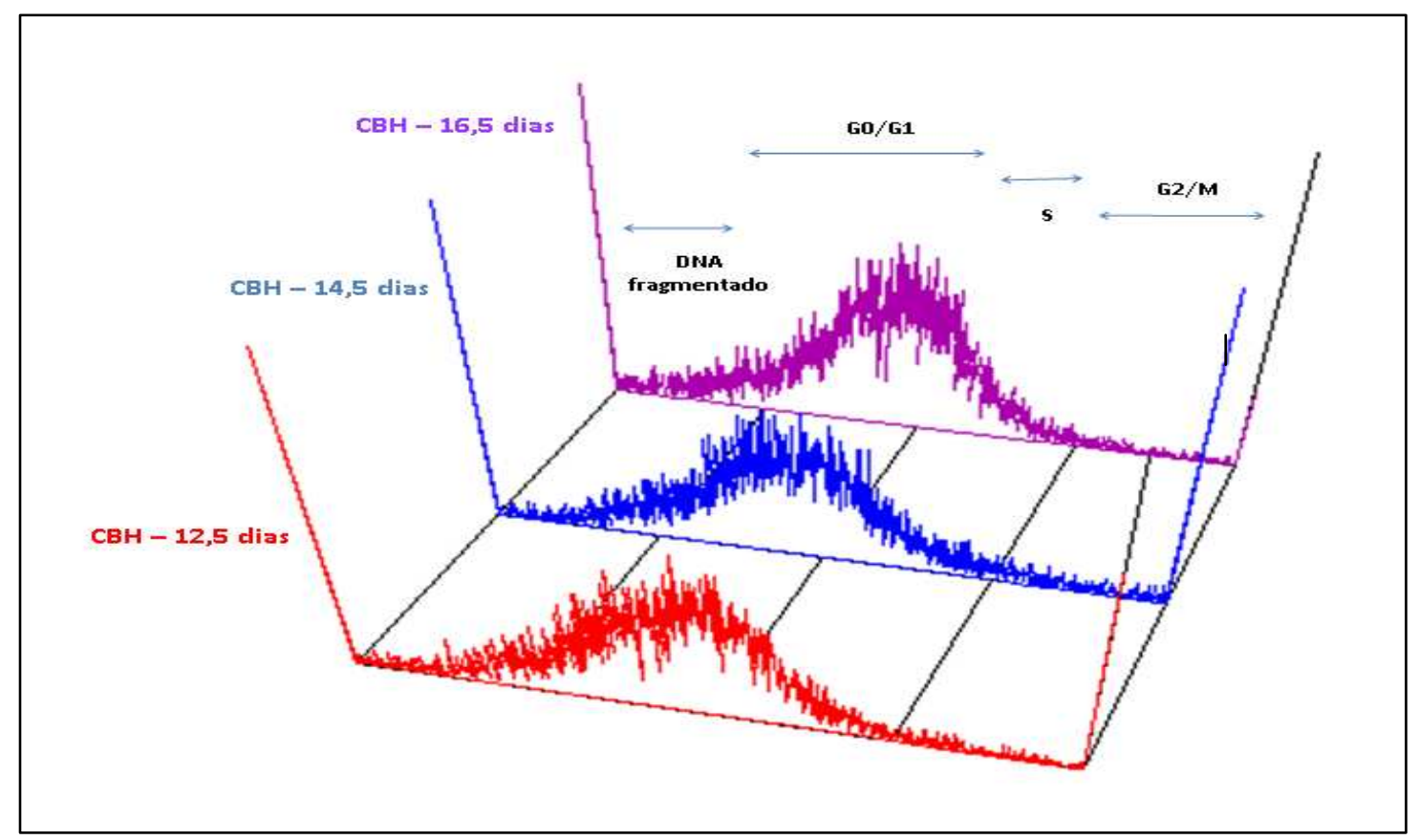

Figura 14 - Histogramas das curvas (overlay) da distribuição do conteúdo do DNA nas diferentes fases do ciclo celular das células do broto hepático de ratos Fischer 344. Em destaque aumento da proporção de células com DNA fragmentado em células CBH 16,5dias e aumento de proporção de células em divisão celular G2/M 


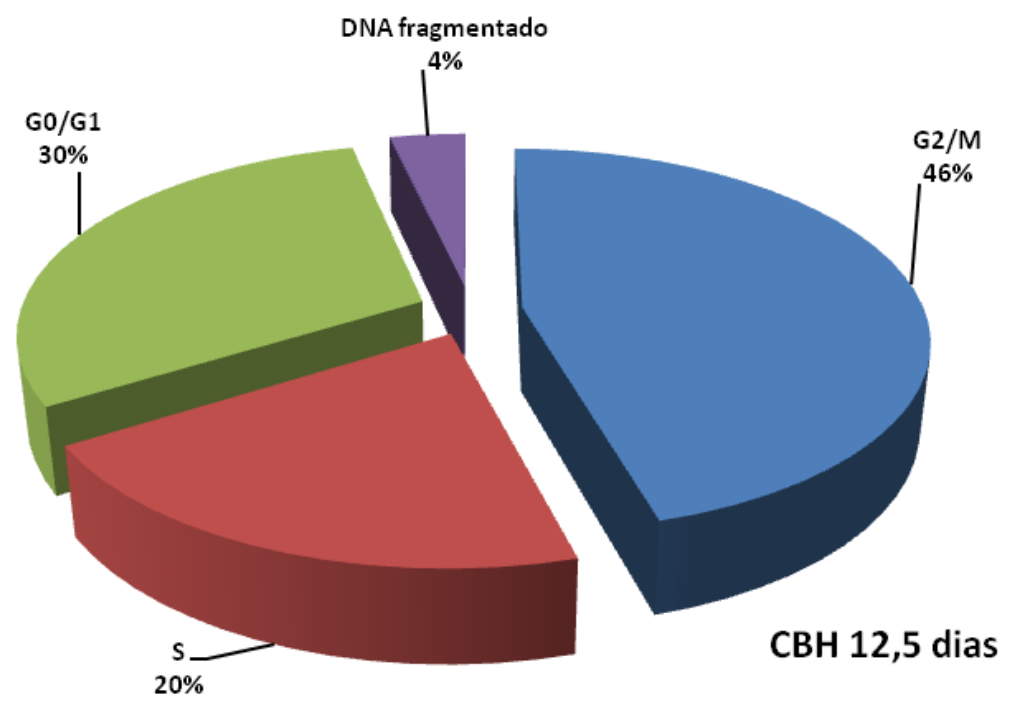

Gráfico 14 - Gráfico das frações das fases do ciclo celular das células do broto hepático $\mathrm{CBH} 12,5$ dias

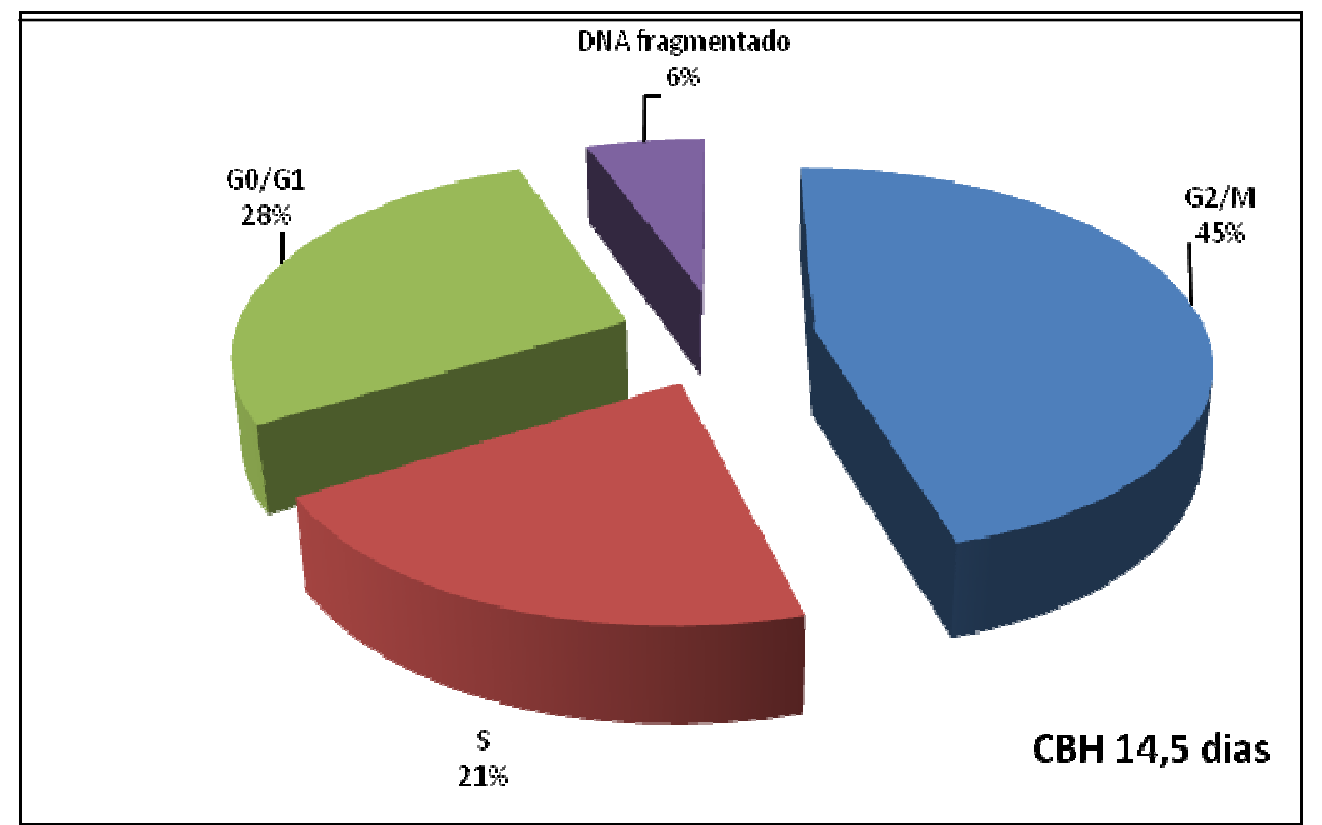

Gráfico 15 - Gráfico das frações das fases do ciclo celular das células do broto hepático $\mathrm{CBH}$ 14,5dias 


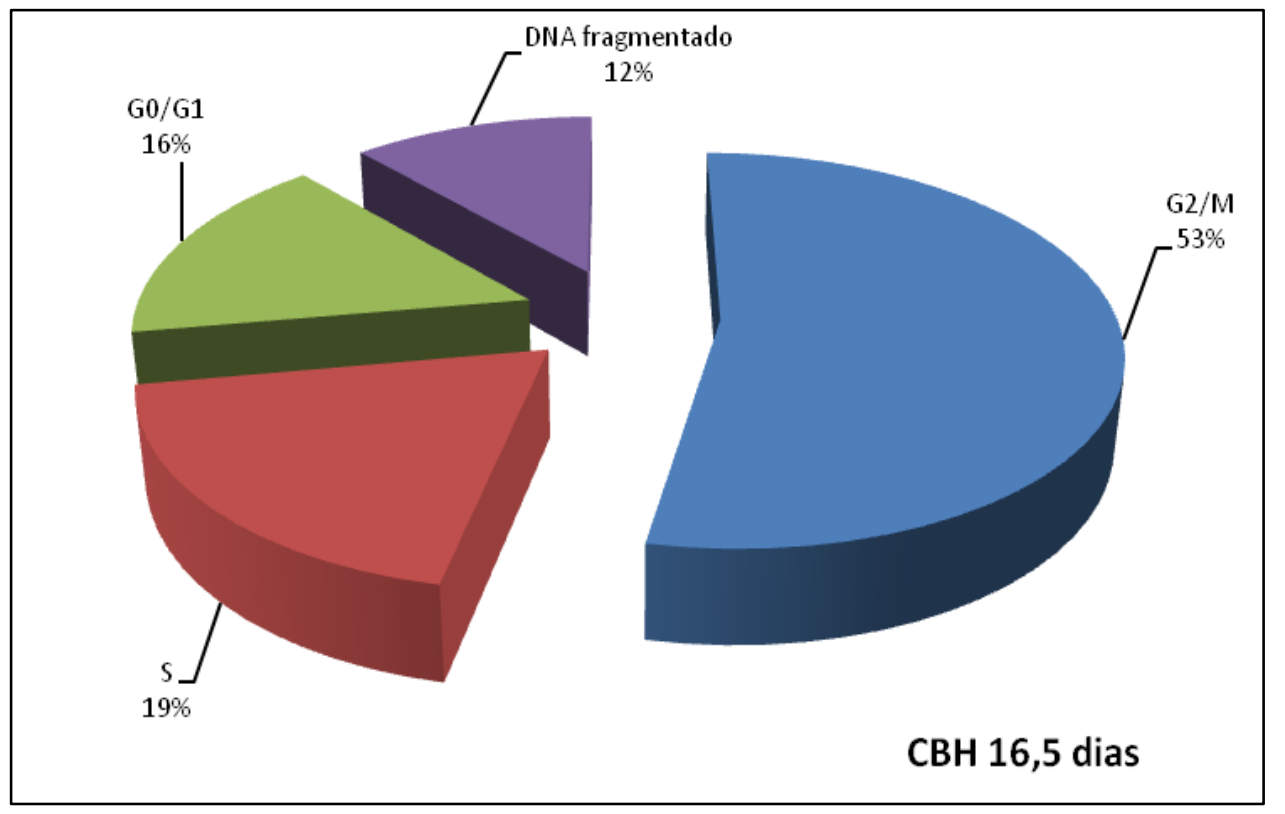

Gráfico 16 - Gráfico das frações das fases do ciclo celular das células do broto hepático CBH 16,5dias

\subsection{Determinação in vitro de produtos da peroxidação lipídica por quantificação de TBARS (LPO)}

Os radicais livres gerados pelas mitocôndrias em resposta a estímulos por diversos agentes, como os fatores de crescimento, citocinas e mediadores de sinalização celular, podem induzir o desacoplamento da cadeia transportadora de elétrons como uma das vias intrínseca de apoptose, pela indução de dano oxidativo de macromoléculas o que leva a apoptose ou ainda serem estímulos para a proliferação, diferenciação e maturação celular.

A produção de espécies reativas, pela detecção do malondialdeído e outros aldeídos de baixo peso molecular que, ao reagirem com o ácido 2-tiobarbitúrico (TBA), formam bases de Schiff. A quantificação do subproduto dialdeído formado não apresentou diferenças significativas de radicais lipoperoxidados, entre as células do $\mathrm{CBH}$ nos diferentes dias de gestação. Foi quantificado a produção do malondialdeído no meio utilizado nas $\mathrm{CBH}$, o meio DMEN - F12 contendo fenol red, os valores obtidos mostram quantidades insignificantes de radicais peroxidados, que 
não interferiram na quantidade real produzida pelas $\mathrm{CBH}$ nos diferentes dias de gestação. Os dados estão representados em quantidade de malondialdeído produzido e expresso em nmol/mL, e apresentados na tabela 9 e gráfico 17.

Tabela 9 - Valores de média \pm DP de expressão de peroxidação lipídica (LPO) das $\mathrm{CBH}$ nos diferentes períodos de gestação em comparação ao meio de cultura e ao hepatócito de rato normal

\begin{tabular}{cc}
\hline $\begin{array}{c}\text { Dias de obtenção das células-tronco de } \\
\text { broto hepático }(\mathbf{n}=\mathbf{0 8})\end{array}$ & $\mathbf{n m o l} / \mathbf{m L}$ \\
\hline $\mathrm{CBH} 12,5$ & $\mathbf{\mathbf { x }} \pm \mathbf{D P}$ \\
\hline $\mathrm{CBH} 14,5$ & $22,7 \pm 6,8$ \\
$\mathrm{CBH} 16,5$ & $20,7 \pm 6,2$ \\
Hepatócito normal & $24,2 \pm 7,2$ \\
Meio de cultura (Controle Basal) & $18,7 \pm 4,6$ \\
\hline
\end{tabular}

$\mathrm{Nmol} / \mathrm{mL} \mathrm{MDA}=$ malondialdeído

$\overline{\mathrm{x}}=$ Média

$\mathrm{DP}=$ Desvio Padrão

$\mathrm{n}=$ Número de amostras analisadas

* Diferenças estatísticas - Teste de Variância de ANOVA. 


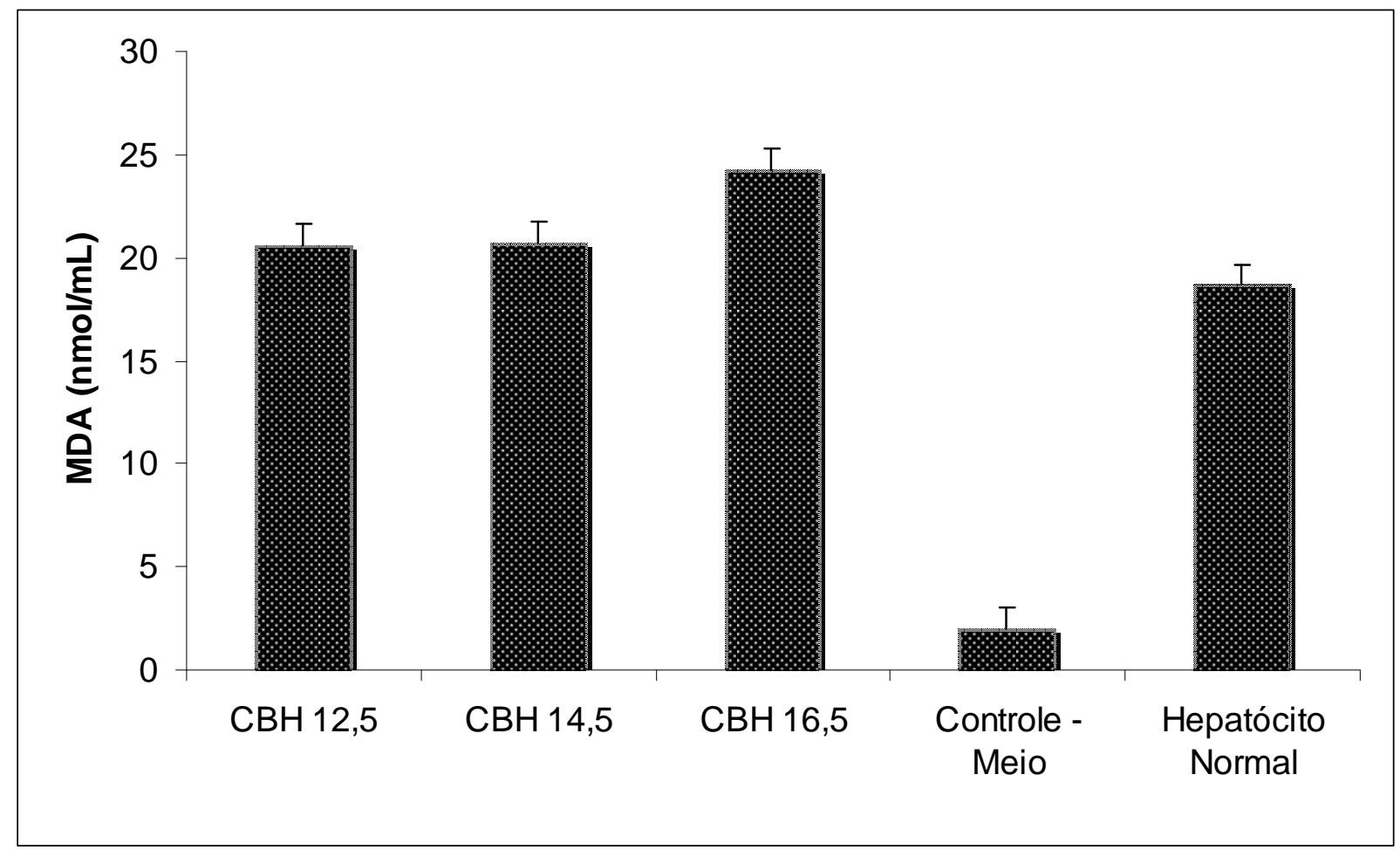

Gráfico 17 - Gráfico de barras representando os valores de média \pm DP para produção de radicais livres lipoperoxidados (LPO) de $\mathrm{CBH}$ nos diferentes dias de gestação em comparação ao meio de cultura e ao hepatócitos de rato normal 


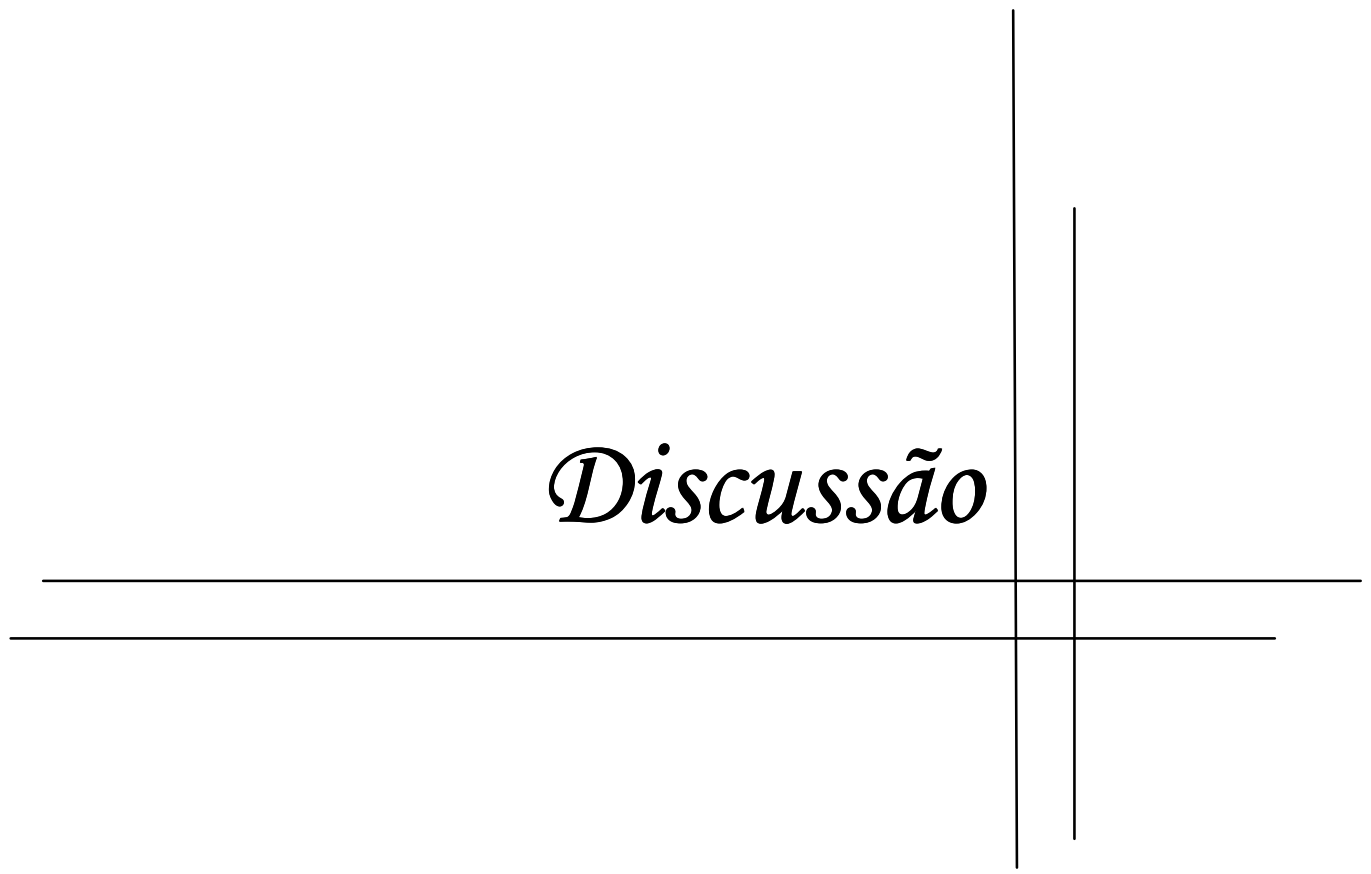




\section{DISCUSSÃO}

As células em cultura mantêm o seu genoma e os mecanismos fundamentais de proliferação e do ciclo celular, representando um modelo para avaliação de diversos testes celulares e bioquímicos substituindo o modelo animal. A metodologia de cultura celular emprega um conjunto de técnicas que permitem cultivar ou manter células isoladas de diferentes fontes, mantendo suas características funcionais e metabólicas próprias (GOLDBERG; MCCULLEY, 1987). Portanto, cada informação genética preservada é inerente a um único genoma, sendo uma particularidade avaliada no modelo desenvolvido neste estudo, no qual as células embrionárias e fetais do broto hepático de ratos Fischer 344 foram submetidas e mantiveram estaveis nos marcadores utilizados para sua caracterização.

O acasalamento dos ratos isogênicos da linhagem Fischer 344 seguiu 0 protocolo de 12 hs de luz, alcançando o índice reprodutivo satisfatório e reprodutível. O isolamento e separação do broto hepático desta linhagem de ratos permitiu o isolamento e expansão de uma cultura primária, em diferentes dias de gestação corraborando com os resultados de Batista et al.(2011).

Neste trabalho foram utilizados embriões de 12,5 dias de gestação e fetos de 14,5 e 16,5 dias de gestação. Contrário ao observado por Passos (2010), que descreveu todos como sendo embriões, este trabalho segue o descrito por Kaufmann (2008), que a partir de 14,5 dias de gestação o embrião já se torna feto por apresentar características específicas da espécie.

As células do broto hepático mantidas em cultura de ratos Fischer demonstraram aspecto de fibroblast like, com a capacidade de sintetizar e organizar uma matriz extracelular com elementos proteicos fibrilares que aumentaram sua organização em culturas de 16,5 dias de gestação. Essas informações foram obtidas a partir das análises realizadas no microscópio eletrônico de varredura, onde os sinais de maior interesse para formação da imagem que evidenciou a organização da matriz extracelular e a maturação das células do broto hepático foram os elétrons secundários responsáveis pela formação da imagem topográfica da superficie das células. A formação do complexo tridimensional da matriz extracelular observada pela $\mathrm{CBH}$ na microscopia eletrônica de varredura supostamente possibilitará a manuntenção destas células em difrentes periodos de gestação que serão uteis para 
as interações entre as células, a sua manutenção e diferenciação, resultados inéditos ainda não relatados na literatura. A matriz extracelular (MEC) é um complexo estrutural formado por diversos glicoaminoglicanas, proteínas estruturais e proteínas especializadas que permitem manter a superfície de contato das células, que permite a associação das superfícies das células ao tecido conjuntivo e a migração. Essas moléculas multifoncionais presentes na MEC têm a capacidade de interagir com vários componentes, apresentando especial afinidade pelos fatores de crescimento e receptores celulares. (YAMADA; KEMLER, 2002). As análises realizadas em microscopia eletrônica varredura mostram a organização tridimensional da matriz extracelular secretada pelas células mesenquimais tronco do broto hepatico, mantidas em cultura nos tres periodos embrionários. As culturas realizadas com fetos de 16,5 dias mostraram que a matriz se organiza de forma a estabelecer conexoes importantes para o estabelecimento de uma rede de suporte e sustentação fibrilar para diferenciação celular.

O desenvolvimento e a manutenção dos tecidos adultos e durante 0 desenvolvimento embrionário depende de diversas células-tronco. As células-tronco são funcionalmente distintas das células progenitoras e são, provavelmente mantidas por mecanismos regulatórios conservados entre as células-troncos de diversos tecidos, ausentes nas células progenitoras indiferenciadas ou primordiais (HE, 1999). A identificação dos genes que são expressos em células-tronco são necessários para que essas células-tronco se mantenham em diversos tecidos, em $\mathrm{CBH}$ foram avaliados os marcadores expressos durante os tres periodos gestacionais; que mostraram capacidade de proliferação e estabilidade na cinética de crescimento celular.

A diferenciação celular resulta da expressão diferencial de genes e de suas proteinas correspondentes, os quais serão expressos em eventos ontogenéticos apropriados. Durante este processo algumas proteínas ou marcadores sao expressos transitoriamente, como a alfa-feto-proteína que é expressa principalmente no período fetal em contraposição à expressão da albumina. Estes dados corroboram com os marcadores avaliados em $\mathrm{CBH}$ de ratos Fischer 344 nos diferentes periodos de gestação. Os marcadores CD90, NANOG, OCT3/4, STRO1 para celulas mesenquimais também mostraram-se transitoriamente expressos em $\mathrm{CBH}$. 
Uma vez obtidas, cultivadas, caracterizadas e diferenciadas as células-tronco de uma maneira geral se tornaram de interesse clínico, apesar da limitação prática, pois há critérios para os receptores histocompatíveis. Recentemente, a indução de pluripotência em fibroblastos primários humanos pela transdução dos genes OCT3/4, C-MYC, KLF4 e SOX2 em vetores virais espécie-específicos mostraram a capacidade de se diferenciar in vitro e in vivo em tecidos derivados dos três folhetos embrionários (Daley, 2010). Neste projeto os marcadores utilizados poderão ser objeto para a transdução e indução de células-troncos derivadas do broto hepático, o conjunto de marcadores expressos $\mathrm{CBH}$ corroboram para sua possível capacidade de pluripotência. A expressão de P53, P21,P27 e Ciclina D1 associadas a quantidade de DNA fragmentado, células em apoptose e a quantidade da caspase 3 foforilada vem de encontro a estabilidade destas células quando mantidas em cultura apresentando propriedades de células-tronco com finalidades terapêuticas. Esses resultados in vitro indicam que estas células não são transformadas e supostamente não desenvolvem tumores em animais imunodeficientes.

A diferenciação celular de hepatócitos foi confirmada pela expressão de marcadores hepáticos como a AFP, Albumina, e as citoqueratinas CK8 e CK18 (BADVE et al., 2000), que também foram avaliadas neste trabalho e se mostraram positivas nos períodos de cultura analisados. As citoqueratinas são constituintes do citoesqueleto das células epiteliais, constituída por uma rede protéica intracelular, de filamentos intermediários, os quais medem de sete a $10 \mathrm{~nm}$; pelos filamentos de actina, de cerca de $7 \mathrm{~nm}$; e pelos microtúbulos, que medem $25 \mathrm{~nm}$.Os microtúbulos estão relacionados com o transporte intracelular de organelas, os filamentos de actina participam da motilidade celular, e os filamentos intermediários dão a estrutura tridimensional da célula (LANGBEIN et al., 1999). Na literatura, definiam 5 tipos de filamentos intermédiários nas células dos vertebrados, distribuídos nos tecidos da seguinte maneira: citoqueratinas (tecido epitelial), vimentina (tecido mesenquimal), desmina (tecido muscular), proteína glial fibrilar ácida astrócitos), neurofilamentos (neurônios) (ALBERTS et al., 1999) corraborando com os nossos achados quando utilizamos os marcadores desmina e citoqueratinas.

A expressão da desmina nas células mesenquimais do broto hepático deste estudo mostrou diminuição significativa no período de 16,5 dias. A sua ocorrência em uma determinada célula varia segundo o tipo histológico, período de 
desenvolvimento embrionário, estado de diferenciação, meio de crescimento corraborando com (CRIBIER; GROSSHANS, 1993; MOLL et al., 1982; ; SMACK; KORGE; JAMES, 1994). A expressão das citoqueratinas 8 e 18 durante o desenvolvimento embrionário do fígado $\mathrm{CBH}$ 12,5 dias apresentou-se aumentada por se tratar do período de embriogênese acordando com (DESMET, 1985; KASPER; KARSTEN, 1990; SHAH; GERBER, 1989; STOSIEK;), razão pela qual utilizamos a citoqueratina CK-8 e CK-18 para a caracterização do tipo celular e no estágio de maturação celular. A citoqueratina 8 e 18 tem um papel fundamental nas vias centrais da apoptose. É uma cisteína protease responsável pela quebra e o empacotamento de componentes celulares para a regulação do ADN.

Nos três períodos de cultura das células do broto hepático de 12,5 a 16,5 dias, a expressão de NANOG foi pequena e ao longo do cultivo ocorre uma diminuição significativa deste marcador, provavelmente relacionado ao seu potencial grau de maturidade demonstrado em blastocisto humano por Constantinescu, (2004).

As transaminases aminotransferase do aspartato (AST) ou transaminase glutâmico-oxalacética (TGO); aminotransferase da alanina (ALT) ou transferase glutâmico pirúvica (TGP) são enzimas que catalisam reações químicas no interior das células, onde um grupo de amino é transferido de uma molécula doadora para uma molécula receptora. Essas enzimas estão presentes nos órgãos como fígado, rins, coração, pâncreas, músculo esquelético, e nos glóbulos vermelho do sangue.

Ambas as aminotransferases estão presentes no soro, em níveis baixos. A aminotransferase do aspartato (AST) ou transaminase glutâmico-oxalacética (TGO) é encontrada, em ordem decrescente quanto à concentração, no fígado, músculocardíaco, músculo-esquelético, rins, cérebro, pâncreas, pulmões, leucócitos e eritrócitos. Os níveis mais elevados de aminotransferase da alanina (ALT) ou transferase glutâmico pirúvica (TGP) são encontrados no fígado, podendo ser considerado marcador específico de dano hepático (ABITBOL et al.,1965). Vale salientar, contudo, que há pouca correlação entre a intensidade de dano hepático e níveis de transaminases, entretando, a diferenciação e a maturação em condições de cultura, podem ser fatores adicionais. $\mathrm{Na}$ análise bioquímica das células do broto hepático, observou-se que o TGO e o TGP apresentavam-se em menor concentração nas $\mathrm{CBH} 12,5$ dias que nos outros períodos estudados. Esses 
resultados relacionam-se ao estadio de diferenciação celular e precocidade da maturação dos hepatoblastos, quando mantidos em cultura os quais foram obtidos de diferentes períodos embrionários.

Se detectada qualquer alteração no genoma celular, este mecanismo interrompe a progressão do ciclo até que seja feito o reparo dependente ou não da expressão da P53; ou se o dano for excessivo, até que a célula entre em apoptose, regulados pela família Bcl-2. Corroborando aos resultados obtidos na expressão dos promotores e reguladores negativos da progressão do ciclo celular, foram encontrados neste trabalho aumento na proporção de células com DNA fragmentado em células do broto hepático de 16,5 dias. Tais informações refletem o estadio de maturação das células do broto hepático, que também foi diferencialmente modulado em hepatócitos normais.

A mitocôndria é responsável pela síntese de quase todo o ATP necessário à manutenção da estrutura e função celular, porém, são também importantes fontes intracelulares de espécies reativas de oxigênio (EROs). A lesão do genoma mitocondrial causa mutações ou deleções dos produtos genéticos mitocondriais, levando a um aumento na concentração dos intermediários reduzidos da cadeia respiratória levando à formação de radicais livres através da sua auto-oxidação. Essa situação proporcionaria um distúrbio no fluxo de elétrons na cadeia respiratória e provocaria um escape de elétrons, resultando em um aumento na geração de radicais livres. De acordo com os dados descritos, propôs-se um ciclo vicioso: lesão do DNA mitocondrial afetaria a função da cadeia respiratória, levando à geração de mais radicais livres que, por sua vez, provocariam lesão adicional ao DNA mitocondrial (BOVERIS; CHANCE, 1973). Células-tronco do broto hepático mostram aumento na atividade funcional e metabólica no fluxo de elétrons em mitocôndrias de 12,5 dias, avaliados pelo potencial elétrico mitocondrial com sonda fluorescente rodamina 123, em comparação aos demais períodos, e se mostram efetivamente produtoras de radicias livres lipoperoxidados no período de 16,5 dias. Estes resultados em suma corroboram aos achados da quantidade de DNA fragmentado e na expressão de P27, como regulador negativo da progressão do ciclo celular, em células de 16,5 dias, o que reflete o seu diferencial estadio de maturação.

As transaminases são enzimas que catalisam reações químicas no interior das células, onde um grupo de amino é transferido de uma molécula doadora para 
uma molécula receptora. Essas enzimas estão presentes nos órgãos como fígado, rins, coração, pâncreas, músculo esquelético, e nos glóbulos vermelho do sangue (ABITBOL et al., 1965). Na análise bioquímica das células do broto hepático, observou-se que o TGO e o TGP apresentavam-se em menor concentração nas $\mathrm{CBH} 12,5$ dias que nos outros períodos estudados.

Células-tronco embrionárias são competentes para a geração de todos os orgãos do feto e tecidos no adulto (YAMANAKA et al., 2008). No entanto, a utilidade das células-tronco embrionárias, como um modelo de desenvolvimento ou como uma fonte de populações de células definidas para a descoberta da novas droga ou para o transplante de orgãos e tecidos é problemática porque a sua diferenciação in vitro ainda não está completamente compreendida (ALECKOVIC; SIMON, 2008; WOBUS et al., 1984). Assim, métodos mais eficientes e seletivos são necessárias para dirigir a diferenciação das células-tronco embrionárias para produzir populações células específicas de maneira homogênea. 


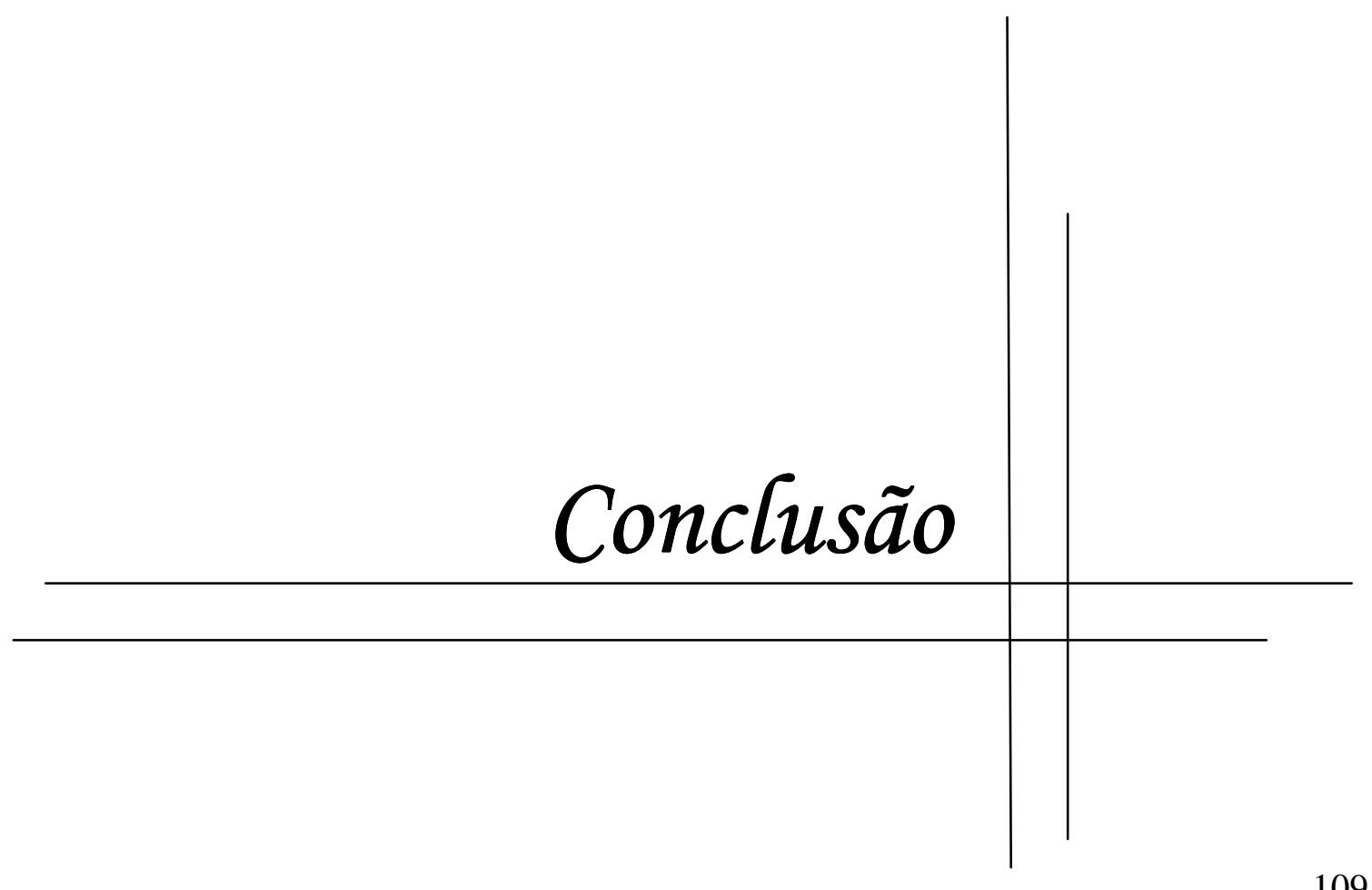




\section{CONCLUSÃO}

- O isolamento e separação do broto hepático de ratos permitiu a obtenção, expansão e caracterização de uma cultura primária, em diferentes dias de gestação 12,5; 14,5 e 16,5 dias;

- Os aspectos morfológicos encontrados foram de células fusiformes do tipo fibroblast-like;

- A expressão dos marcadores de células-tronco de origem mesenquimais (CD90, Nanog, Oct 3/4 e STRO1), marcadores do citoesqueleto (CK8, CK18 e Desmina), marcadores envolvidos na checagem e progressão do ciclo celular (P53, P21, P27 e Ciclina D1), marcadores envolvidos na morte celular (Anexina V/PI, Caspase 3, Bax, Bad e Bcl2) mostraram diferencialmente expressos, nos diferentes períodos de gestacionais; sugerindo que podemos considerá-las a célula do broto hepático como células -tronco;

- As análises das transaminases hepáticas TGO e TGP, mostraram se em concentrações menores no período 12,5 dias; indicativo que as células neste período estão indiferenciadas;

- Na análise do potencial elétrico mitocondrial nos períodos de gestação de 14,5 e 16,5 dias, observou-se nas CBH o aumento na proporção de células inativas com menor capacidade funcional ou metabólica, quando comparada ao período de 12,5 dias ou mesmo em relação ao hepatócito de normal; sugerindo ser mais um indicativo de idade adequada para coleta;

- Análise das fases do ciclo celular observou-se um acúmulo na fase G0/G1, repercutindo na modulação da capacidade de proliferação e aumento na proporção de células com DNA fragmentado, nas CBH no período de 16,5 dias em comparação aos demais períodos e ao hepatócito normal. 
- Os reguladores da progressão do ciclo celular em células do broto hepático aumentaram progressivamente nos períodos de cultura e após o seu descongelamento e expansão são capazes de manter a expressão de seus marcadores específicos. Não ocorreu modificações nas expressões das proteínas P53 reparo de DNA ou antiapoptóticas BCL-2 .

- Os radicais livres lipoperoxidados mostram quantidades insignificantes em $\mathrm{CBH}$ nos diferentes dias de gestação.

- As linhagens $\mathrm{CBH}$ nos diferentes períodos de gestação obtidas neste trabalho, mostraram-se com grande capacidade proliferativa, mantendo-se pluripotente principalmente nos períodos 12,5 e 14,5 dias de gestação, não apresentando marcadores de transformação neoplásica ou de erros genéticos, que controlam a progressão de crescimento e diferenciação celular normais. 


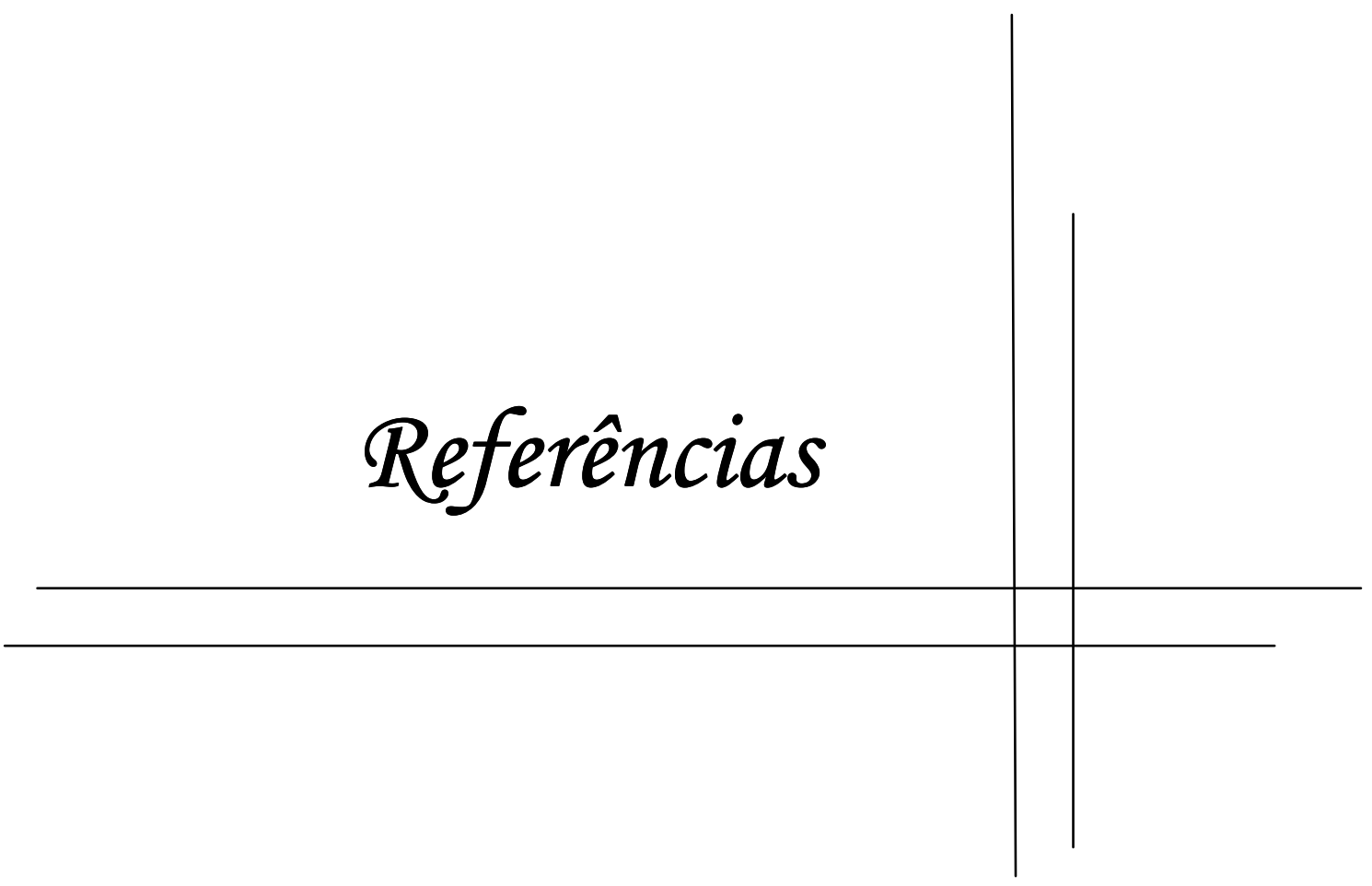




\section{REFERÊNCIAS}

ABITBOL, L.; VILLELA, R. A.; ABITBOL, A.; ABRANTES, I. B.; FLEURY, A.; VILLELA, A. A. Relação topográfica entre a transaminase glutâmico-oxalacética e as diferentes áreas de comprometimento elétrico do coração. Arquivos brasileiros de cardiologia., 1965.

ALBERTS, B.; BRAY, D.; JOHNSON, A. O citoesqueleto. In: ALBERTS B, BRAY D, JOHNSON A, LEWIS J, RAFF M, ROBERTS K, WALTER P. Fundamentos da biologia celular- uma introdução à biologia molecular da célula. Porto Alegre: Artmed 1999: 526-60.

ALECKOVIC, M.; SIMÓN, C. Is teratoma formation in stem cell research a characterization tool or a window to developmental biology? Reproductive BioMedicine Online, v. 17,p. 270-280, 2008.

BADVE, S.; LOGDBERG, L.; SOKHI, R. GRECO, M.T.G.; MITSUDO, S.; SAXENA, $R$. An antigen reacting with das -1 monclonal antibody is ontogenetically regulated in diverse organs including liver and indicates sharing of developmental mechanisms among cell lineages. Pathobiology, v.68, p.76-86, 2000.

BAHARVAND, H.; HASHEMI, S. M.; KAZEMI, S.; ASHTIANI, K.; FARROKHI, A. Differentiation of human embyonic stem cells into hepatocytes in 2D and 3D culture systems in vitro. International journal developmental biology, v.50, p.645-652, 2006.

BANKS, W. J. Histologia veterinária aplicada. 2. ed. Rio de Janeiro: Manoele;1992. 629 p.

BATISTA, A.B.; MORITA, E.L.;PASSOS, C.C., FERREIRA, A.O.; ALVES, F.R.; ALVES, A.J.; MIGLINO, M.A.; GUERRA,R.R. Efeito da periodicidade na taxa de prenhez em ratos isogênicos. Ciência Rural, v.41, n.1, 2011.

BECKER, A. J., MCCULLOCH, E. A.; TILL, J. E. Cytological demonstration of the clonal nature of spleen colonies derived from transplanted mouse marrow cells. Nature,. v. 4, n.50, p 452, 1963.

BEHRENS, A.; SIBILIA, M.; DAVID, J. P.; UTA, M.S.; TRONCHE, F.; SCHUTZ, G.; WAGNER, F.W. Impaired postnatal hepatocyte proliferation and liver regeneration in mice lacking c-jun in the liver. The embo journal, v.21, p.1782-1790, 2002.

BISGAARD, H. C.; TON, P. T.; NAGY, P.; THORGEIRSSON, S.S. Phenotypic modulation of keratins, vimentin, and alpha-fetoprotein in cultured rat liver epithelial 
cells after chemical, oncogene, and spontaneous transformation. Journal of cellular physiology, v.159, n.3, p. 485-494, 1994.

CAPLAN, A. I. Mesenchymal stem cells. Journal of orthopaedic research, v. 9, p. 641-650, 1991.

CAPLAN, A. I. Tissue engineering. v.11, p.1198-1211, 2005.

CHAMBERS, I.; COLBY, D.; ROBERTSON, M.; NICHOLS, J.; LEE, S.; TWEEDIE, S.; SMITH, A. Functional expression cloning of Nanog, a pluripotency sustaining factor in embryonic stem cells, Cell, v.113, p. 643-655, 2003.

CHORNA, I. V.; DATSYUK, L. O.; STOIK, R. S. Expression of Bax, Bad and Bcl-2 proteins under x-radiation effect towards human breast carcinoma MCF-7 cells and their doxorubicin- resistant derivatives. Experimental oncology, v.27, n.3, p.196201, 2005.

COHEN, P.T.W. Novel protein phosphatases: variety is the spice of life. Trends in biochemical sciences, v. 22, p.245-251, 1997.

CONSTANTINESCU, S. Stemness, fusion and renewal of hematopoietic and embryonic stem cells. Journal of cellular and molecular medicine, v. 7,n. 2, p. 103-12, 2004.

COQUERET, O. New roles for $\mathrm{p} 21$ cell cycle inhibitors: a function for each cell compartment? Trends in Cell Biology, v.13, n. 2, p. 65-70, 2003.

COSTA, R. H.; KALINICHENKO, V. V.; HOLTERMAN, A. X.; WANG, X. Transcription factors in liver development, differentiation, and regeneration. Hepatology, 38:13311347, 2003.

DALEY, G. Q.; LENSCH, M. W.; JAENISCH, R.; Meissner, A.; Plath, K.; Yamanaka, S. Cell Stem. Cell, v. 4, p.200-201, 2009.

DUNCAN, S. A. Mechanisms controlling earky development of the liver. Mech develop, v.120, p.19-33, 2003.

DUNCAN, S. A. Tanscriptional regulation of the liver development. Developmental dynamics, v.219, p.131-142, 2000.

DUNCAWOODIE, S. L.; RODRIGUEZ, T. A.; BEDDINGTON, R. S. P. Msg1 and Mrg1, founding members of a gene family, show distinct patterns of gene expression during mouse embryogenesis. Mech develop, v.72, p. 27-40, 1998.

DUNWOODIE, S. L. Loss of Cited2 affects trophoblast formation and vascularization of the mouse placenta. Developmental biology, v.294, p. 67-82, 2006.

FIEGEL, H. C.; LANGE, C.; KNESER, W.; LAMBRECHT, W.; ZANDER, A.R.; ROGIERS, X.; KLUTH, D. Fetal and adult liver stem cells for liver regeneration. Journal of cellular and molecular medicine, v.10, p.577-587, 2006. 
FRIEDENSTEIN, A. J.; CHAILAKHYAN, R. K.; GERASIMOV, U. V. Bone marrow osteogenic stem cells: in vitro cultivation and transplantation in diffusion chambers. Cell tissue kinet. v.20, n 3, p. 263-272, 1987.

GOLDBERG, A.; MCCULLEY, J. P. Alternative methods in toxicology. New York: Mary Ann Liesbert, v.4, 1987.

GOTTINGEN, G. Characterization of foetal hepatic cells during rat liver development. 2006. p.144. Dissertation Erlangung des Doktorgrades der Mathematisch-Naturwissenschaftlichen Fakultäten der Georg-August-Universität zu vorgelegt von Abderrahim Elmaouhoub Aus Rabat, Marokko, 2006.

GRAPIN-BOTTON, A. Antero-posterior patterning of the vertebrate digestive tract: 40 years after Nicole Le Douarin's PhD thesis. International journal developmental biology, v.49, p.335-347, 2005.

GREEN, D. R.; KROEMER, G. Trends cell biology, v. 8, p. 267-271, 1998.

GRIVICICHI, I.; REGNER, A.; ROCHA, A. B. Morte cellular por apoptose. Revista brasileira de cancerologia, v.53, n.3, p. 335-343, 2007.

HAIL J. R, N.; CARTER, B. Z.; KONOPLEVA, M.; ANDREEFF, M. Apoptosis effector mechanisms: A requiem performed in different keys. Apoptosis, v. 11, p. 889-904, 2006.

HAJRA, K.M.; LIU, J. R. Apptosome dysfunction on in human cancer. Apoptosis,v.9, p. 691-704, 2004.

HE, Z.; BATEMAN, A. Progranulin gene expression regulates epithelial cell growth and promotes tumor growth in vivo. Cancer research, v. 59, p. 3222-3229, 1999.

HOWARD, A; PELC, S. R. Synthesis of deoxyribonucleic acid in normal and irradiated cells and its relation to chromosome breakage. Heredity.v.26 p.261-273, 1953.

JUNQUEIRA, L.C.; CARNEIRO, J. Histologia básica. 10.ed. Rio de Janeiro: Guanabara Koogan, p.488, 2004.

KAUFMAN, M. H.; BARD, J. B. L. The anatomical basis of mouse development. New York: Academic Press, p.291, 1999.

KIERSZENBAUM, A. L. Histologia e biologia celular: uma introdução à patologia. Rio de Janeiro, Elsevier, 2008. 677p.

KIYOTA, A.; MATSUSHITA, T.; UEOKA, R. Induction and high density culture of human hepatoblasts from fetal hepatocytes with suppressing transformation.

Biological and pharmaceutical bulletin, v.30, p. 2308-2311, 2007. 
KROEMER, G.; GALLUZZI, L.; BRENNER, C. Physiology, v. 87, p. 99-163, 2007.

LANGBEIN, L.; ROGERS, M.A.; WINTER, H.; PRAETZEL, S.; BECKHAUS, U.; RACHWITZ, H.R.; SCHWEIZER, J. The catalog of human hair keratins I. Expression of the nine type I members in the hair follicle. Journal of biology chemistry, 1999; 274: 19.874-84.

LJUBIMOVA J. Y.; PETROVIC L. M.; WILSON S. E.; GELLER, S.A.; DEMETRIOU, A.A. Expression of HGF, its receptor c-met, c-myc, and albumin in cirrhotic and neoplastic human liver tissue. Journal of histochemistry and cytochemistry. v.45, p.79-87, 1997.

MALHI, H.; IRANI, A. N.; GAGANDEEP, S.; GUPTA, S. Isolation of human progenitor liver epithelial cells with expansive replication capacity and differentication into mature hepatocyte. Journal of cellular science, v.115, p. 2679-2688, 2002.

MCLIN, V. A.; ZORN, A. M. Molecular control of liver development. Clinics in liver disease, 10:1-25, 2006.

MEPLAN, C.; RICHARD, M.J.; HAINAUT, P. Redox signalling and transition metals in the control of the P53 pathway. Biochemical pharmacology , v.59, p. 25-33, 2000.

MIAO, E. A.; ALPUCHE-ARANDA, C. M.; DORS, M.; CLARK, A. E.; BADER, M. W.; MILLER, S. I.; ADEREM, A. Cytoplasmic flagellin activates caspase-1 and secretion of interleukin $1 \beta$ via Ipaf. Nature immunology, v. 7, p. 569-575, 2006.

MIGLIACCIO, G.; MIGLIACCIO, A. R.; PETTI, S.; MAVILIO, F.; RUSSO, G.; LAZZARO, D.; TESTA, U.; MARINUCCI, M.; PESCHLE, C. Human embryonic hepatompoiesis: kinetics of progenitors and precursors underlying the yolk sac-liver transition. Journal of clinical investigation., v.78, p.51-60, 1986.

MITSUI, K.; TOKUZAWA, Y.; ITOH, H.; SEGAWA, K.; MURAKAMI, M.; TAKAHASHI, K.; MARUYAMA, M.; MAEDA, M.; YAMANAKA, S. The homeoprotein Nanog is required for maintenance of pluripotency in mouse epiblast and ES cells. Cell. v.113, n 5, p. 631-42, 2003.

MONIE, I. W. Comparative development of the nervous, respiratory, and cardiovascular systems. Environ health perspect, v.18, p. 55-60, 1976.

MURACA, M.; GERUNDA, G.; NERI, D. Hepatocyte transplantation as a treatment for glycogen storage disease type 1a. The lancet, v.359, p.317-318, 2002.

NYAMATH, P.; ALVI, A.; HABEEB, A.; KHOSLA, S.; KHAN, A. A.; HABIBULLAH, C. $M$. Characterization of hepatic progenitors from human fetal liver using CD34 as a hepatic progenitor marker. World journal of gastroenterology, v. 13, p. 2319-2323, 2007. 
OKAMOTO, K.; OKAZAWA, H.; OKUDA, A.; SAKAI, M.; MURAMATSU, M.; HAMADA, $\mathrm{H}$. A novel octamer binding transcription factor is differentially expressed in mouse embryonic cells. Cell, v. 60, p. 461-472, 1990.

PAN, G.; THOMSON, J. A. Nanog and transcriptional networks in embryonic stem cell pluripotency. Cell Res, v. 17, p.42-49, 2007.

PARK, L. K.; LEE, D. H. J. Journal of bioscience and bioengineering, v. 99, p.311-319, 2005.

PARK, W. S.; OH, R. R.; PARK, J. Y.; KIM, P.J.; SHIN, M.S.; LEE, J.H.; KIM, H.S.; LEE, S.H.; KIM, S.Y.; PARK, Y.G.; AN, W.G.; KIM, H.S.; JANG, J.J.; YOO, N.J.; LEE, J.Y. Nuclear localization of beta-catenin is an important prognostic factor in hepatoblastoma. J. Pathology, v.193, p.483- 490, 2001.

PARVIZ, F.; MATULLO, C.; GARRISON, W. D.; SAVATSKI, L.; ADAMSON, J. W.; NING, G.; KAESTNER, K. H.; ROSSI, J. M.; ZARET, K. S.; DUNCAN, S. A. Hepatocyte nuclear factor $4 \alpha$ controls the developmental of a hepatic epithelium and liver morphogenesis. Nature genetic, v.34, p. 292-296, 2003.

PASSOS, C. C. Função do fator de crescimento progranulina na diferenciação e proliferação de células de linhagem hepática, durante o desenvolvimento embrionário de ratos Fischer 344. 2010. 89f. Dissertação (Mestrado). Faculdade de Medicina Veterinária e Zootecnia, Universidade de São Paulo, São Paulo, 2010.

PESCE, M.; SCHÖLER, H. R. Oct-4: gatekeeper in the beginnings of mammalian development. Stem Cells, v.19, p. 271-278, 2001.

PITTENGER, M. F.; MACKAY, A. M.; BECK, S. C.; JAISWAL, R. K.; DOUGLAS, R.; MOSCA, J. D.; MOORMAN, M. A.; SIMONETTI, D. W.; CRAIG, S.; MARSHAK, D. R. Multilineage potential of adult human mesenchymal stem cells. Science, v. 284, n. 5411, p. 143-147, 1999.

POUTON, C. W.; HAYNES, J. M. Pharmaceutical applications of embryonic stem cells. Advaned drug delivery reviews, v.57, p. 1918-1934, 2005.

QU, X.; LAM, E.; DOUGHMAN, Y. Q. Cited2, a coactivator of HNF4a, is essential for liver development. The EMBO Journal, v.26, p. 4445-4456, 2007.

REGE, T.; HAGOOD, J. S. Thy-1 como um regulador de célula-célula e matriz de interações celulares na regeneração de axônios, apoptose, adesão, migração, câncer e fibrose. The FASEB journal, v. 20, n.8, p. 1045-1054, 2006.

ROSSANT, J.; TAM, P. P. Mouse development: patterning, morphogenesis, and organogenesis. San Francisco: Academic Press, p.736, 2002.

ROSNER, M. H.; VIGANO, M. A.; OZATO, K.; TIMMONS, P.M.; POIRIER, F.; RIGBY, P.; STAUDT, L. M. A POU-domain transcription factor in early stem cells and germ cells of the mammalian embryo. Nature, v. 345, p. 686-692, 1990. 
SAELENS, X; FESTJENS, N; VANDE, L; VAN GURP, M; VAN LOO, G;

VANDENABEELE, $P$. Toxic proteins released from mitochondria in cell death.

Oncogene, v.,6 p. 2861-2874, 2004.

SAKATA, H.; TAKAYAMA, H.; SHARP, R. Hepatocyte growth factor/scatter factor overexpression induces growth, abnormal development, and tumor formation in transgenic mouse livers. Cell growth and differentiation., v.7, p. 1513-1523, 1996.

SCHWABE R. F.; BRADHAM C. A.; UEHARA T. c-Jun-N-terminal kinase drives cyclin D1 expression and proliferation during liver regeneration. Hepatology, v.37, p. 824- 832, 2003.

SCHÖLER, H. R.; RUPPERT, S.; SUZUKI, N.; CHOWDHURY, K.; GRUSS, P. New type of POU domain in germ line-specific protein Oct-4. Nature, v.29; n. 344(6265), p.435-439, 1990.

SELDEN, C.; HODGSON, H. Cellular therapies for liver replacement. Transplant immunology, v.12, p. 273-288, 2004.

SHIOJIRI, N.; KOIKE, T. Differentiation of biliary epithelial cells from the mouse hepatic endodermal cells cultured in vitro. Journal of experimental medicine, v.181, p.1-8, 1997.

SICLARI, V.; QIN, L. Targenting the osteosarcoma cancer stem cell. Jounal of Orthopaedic Surgery and Research, v.5,n.78, 2010.

SIMMONS, P. J.; TOROK-STORB, B. Identification of stromal cell precursors in human bone marrow by a novel monoclonal antibody,STRO-1. Blood, v.78, n.1, p. 55-62, 1991.

SPENCE, J. R.; WELLS, J. M. Translational embryology: using embryonic principles to generate pancreatic endorine cells from embryonic stem cells. Developmental Dynamics., v.236, p. 3218-3227, 2007.

STEBEL, M; VATTA, P; RUARO, M. E; DEL SAL, G; PARTON, R. G. The growth suppressing gas1 product is a GPI-linked protein. FEBS Letters, v. 481, p. 152-158, 2000.

STOSIEK, P.; KASPER, M.; KASTER, U. Expression of Cytokeratin 19 During Human Liver Organogenesis, Liver, v.10, p. 59-63, 1990.

STURM J.; KEESE M.; ZHANG H. et al. Liver regeneration in FGF-2-deficient mice: VEGF acts as potential functional substitute for FGF-2. Liver International., v. 24, p.161- 168, 2004.

TAKAYASU, H.; HORIE, H.; HIYAMA, E. Frequent deletions and mutations of the beta-catenin gene are associated with overexpression of cyclin D1 and fibronectin and poorly differentiated histology in childhood hepatoblastoma. Clinical cancer research., v.7, p. $901-908,2001$. 
TAKAHASHI, K.; YAMANAKA, S. Induction of pluripotent stem cells from mouse embryonic and adult fibroblast cultures by defined factors. Cell , v.126, p. 663-676, 2006.

THONSON, J. A.; ITSKOVITZ-ELDOR, J.; SHAPIRO, S. S.; WAKNITZ, M. A.; SWIERGIEL, J. J.; MARSHALL, V. S. ET AL. Embryonic stem cell lines derived from human blastocysts. Science, v.282, p. 1145-1147, 1998.

TRIEB, K.; KOTZ, R. Proteins expressed in osteosarcoma and serum levels as prognostic factors. The international journal of biochemistry \& cell biology, v.33, p. 11-17, 2001.

TOKUZAWA, Y.; MITSUI, K; ITOH, H.; SEGAWA, K.; TAKAHASHI, K.; MARUYAMA, M.; MAEDA, M.; YAMANAKA, S. O. Nanog homeoprotein é necessária para a manutenção da pluripotência em epiblasto rato e células-tronco embrionárias:. Cell., v.113, n. 5, p. 631-42, 2003.

VASCONCELOS, L. A .B .A.; ALMEIADA, E. A.; BACHUR, L. F. Avaliação clínica e laboratorial hepática em indivíduos com insuficiência cardíaca congestiva. Arquivos brasileiros de cardiologia. v. 85, n. 5, p. 590-595, 2007.

WANG X.; BHATTACHARYYA D.; DENNEWITZ M. B. et al. Rapid hepatocyte nuclear translocation of the Forkhead Box M1B (FoxM1B) transcription factor caused a transient increase in size of regenerating transgenic hepatocytes. Gene Expression., v.11, p.149-162, 2003.

WANG X.; KIYOKAWA H.; DENNEWITZ M. B. et al. The Forkhead Box m1b transcription factor is essential for hepatocyte DNA replication and mitosis during mouse liver regeneration. Proceeding national academy of science. U. S. A., v.99, p.16881-16886, 2002.

WATANABE, F. D.; MULLON, C. J.; HEWITT, W. R.; ARKADOPOPULOS, N.; KAHAKU, E.; EGUCHI, T.; KHALILI, T.; ARNAUT, W.; SHACKLETON, C. R. ROZGA, J.; SOLOMON, B.; DEMETRIOU, A. A. Annals of sugery, v.225, p. 484494, 1997.

WATT, A. J.; GARRISON, W. D.; DUNCAN, S. A.; PHIL, D. hnf4: a central regulator of hepatocyte differentiation and function. Hepatology, v.37, p.1249-1253, 2003.

WITHINGTON, S. L.; SCOTT, A. N.; SAUNDERS, D. N.; LOPES, F. K.; PREIS, J. I.; MICHALICEK, J.; MACLEAN, K.; SPARROW, D. B.; BARBERA, J. P.; YAMADA, K.M.; KEMLER, R. Cell to cell contact and extracellular matrix. Current opinion in Celle Biology, v.14, p. 527-530, 2002.

YAMANAKA, K., CHUN, S.J., BOILLEE, S., FUJIMORI, N., YAMASHITA, H., GUTMANN, D.H., MISAWA, H., TAKAHASHI, R., CLEVELAND, D.W. Nature neuroscience, v.11, p. 251-253, 2008. 
YANG C.; ZEISBERG M.; LIVELY J. C. et al. Integrin alpha1beta1 and alpha2beta1 are the key regulators of hepatocarcinoma cell invasion across the fibrotic matrix microenvironment. Cancer research, v.63, p. 8312-8317, 2003.

YE, X.; BISHOP, A. M.; NEEDHAM, L. L.; CALAFAT, A. M. Identification of metabolites of 4-nonylphenol isomer 4-(3',6'-dimethyl-3'-heptyl) phenol by rat and human liver microsomes. Drug Metabolism Disposal, v. 35, p. 1269-1274, 2007.

ZAGO, M. A.; COVAS, D. T. Células-tronco: a nova fronteira da medicina. São Paulo: Atheneu, 2006. 245p.

ZARET, K. S. Regulatory phases of early liver development: paradigms of organogenesis. Nature reviews genetics., v. 3, p. 499-512, 2002.

ZHANG, B.; SCHMOYER, D.; KIROV, S.; SNODDY, J. GOTree Machine (GOTM): a web-based platform for interpreting sets of interesting genes using Gene Ontology hierarchies. BMC Bioinformatics, v. 516, 2004.

ZHOU, Q.J.; HUANG, Y.D.; XIANG, L.X. In vitro differentiation of embryonic stem cells into hepatocytes induced by fibroblast growth factors and morphological protein4. The Internacional Journal of Biochemistry \& Cell Biology, v. 39, p. 1714-1721, 2007. 


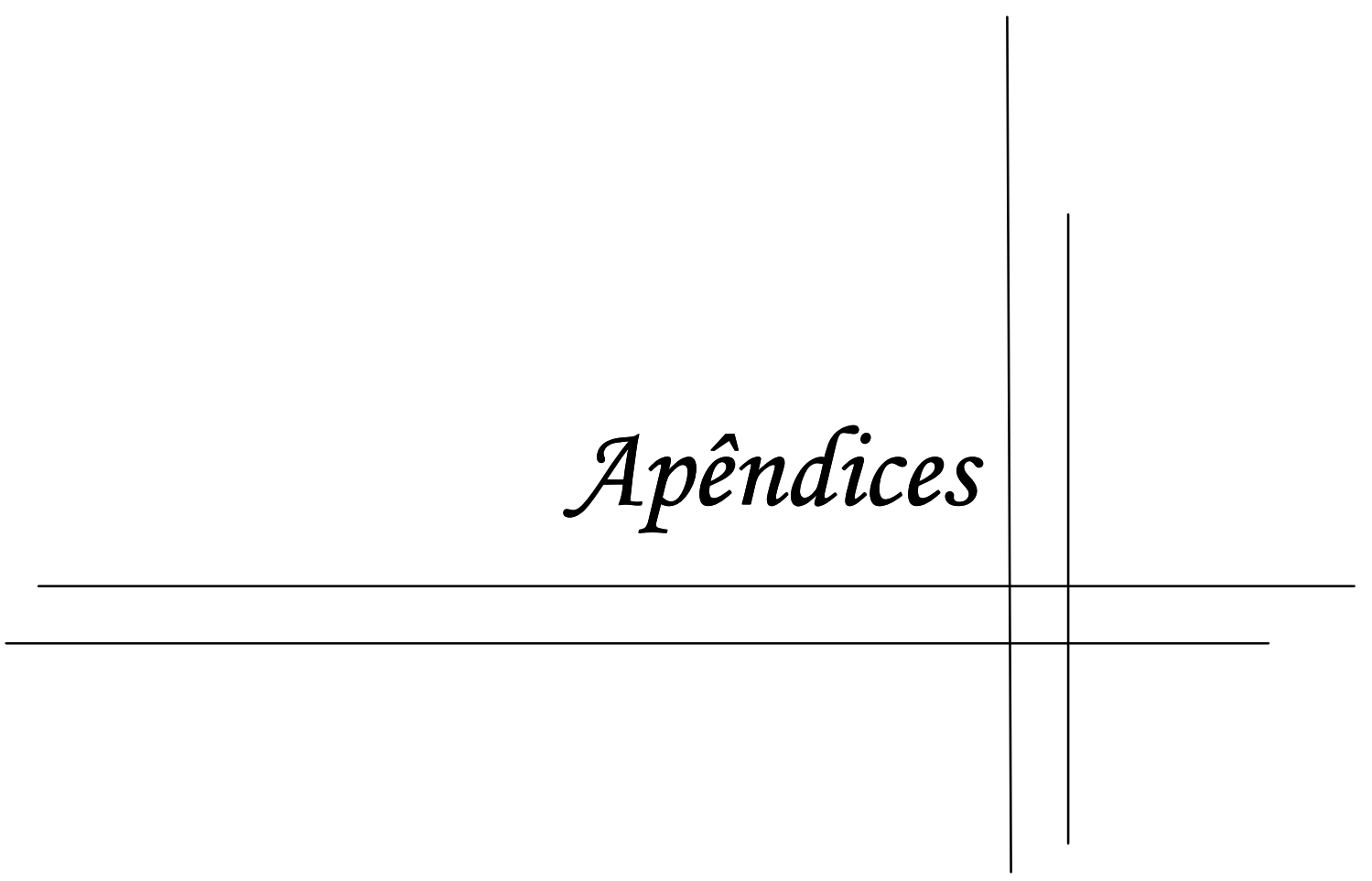




\section{APÊNDICES}

Apêndice A - Análise estatística do broto hepático de ratos Fischer 344 em diferentes idades gestacionais 12,$5 ; 14,5$ e 16,5 dias, para TGO

\begin{tabular}{|c|c|c|c|c|}
\hline \multicolumn{5}{|c|}{ One-way Analyaig of Variance (HWOWA' } \\
\hline \multicolumn{5}{|c|}{$\begin{array}{l}\text { The F value is < } 0.0001 \text {, considered extremely significant. } \\
\text { variation among colum means is significantly greater than expecte } \\
\text { by chance. }\end{array}$} \\
\hline \multicolumn{5}{|c|}{$\begin{array}{l}\text { Tukey-Kramer Multiple comparisong Test } \\
\text { If the value of a is greater than } 3.9 .58 \text { then the F value is less } \\
\text { than 0.05. }\end{array}$} \\
\hline Comparison & $\begin{array}{c}\text { Mean } \\
\text { Difference }\end{array}$ & $\mathbf{q}$ & & yalue \\
\hline 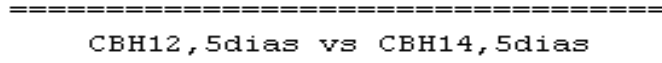 & $\begin{aligned}== & ====== \\
& -31.800\end{aligned}$ & $\begin{aligned} &====== \\
& 28.1 .51\end{aligned}$ & $\begin{array}{l}==== \\
\approx *\end{array}$ & $\begin{array}{l}====== \\
F<0.001\end{array}$ \\
\hline CBH12, 5dias va CBH16,5dias & -32.700 & 28.948 & $* *$ & $P<0.001$ \\
\hline CEH12, Saias va Hepat. normais & -5.600 & 4.957 & * & $P<0.05$ \\
\hline CEH14, 5dias va CEH16, 5dias & -0.9000 & 0.7967 & $\mathrm{n} \Xi$ & $P>0.05$ \\
\hline CEH14, sdias va Hepat. normais & 26.200 & 23.194 & $* * *$ & $P<0.001$ \\
\hline CEH16, Sdias va Hepat. normais & 27.100 & 23.991 & 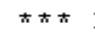 & $F<0.001$ \\
\hline
\end{tabular}

Apêndice B - Análise estatística do broto hepático de ratos Fischer 344 em diferentes idades gestacionais 12,$5 ; 14,5$ e 16,5 dias, para TGP

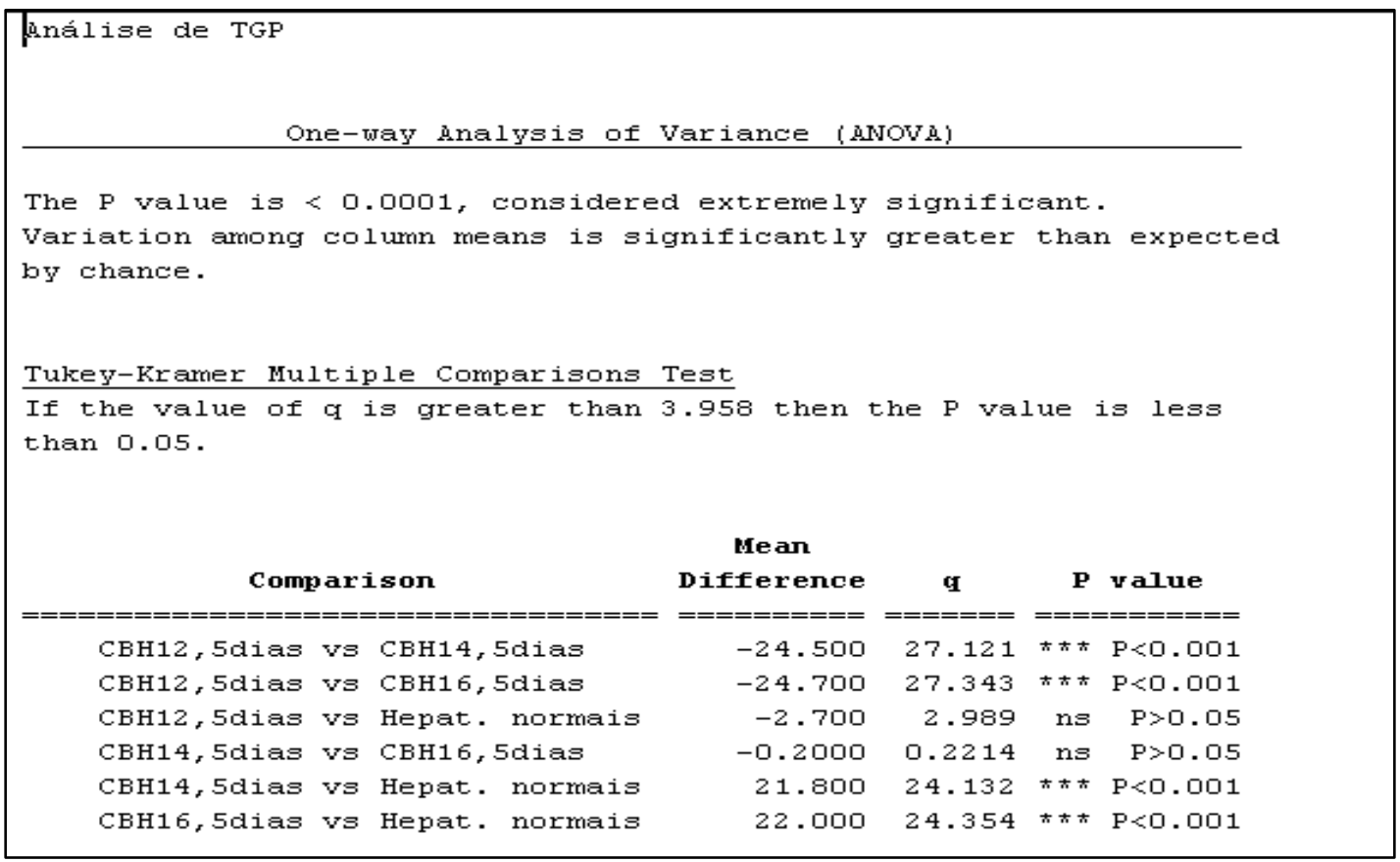


Apêndice C - Análise estatística do broto hepático de ratos Fischer 344 em diferentes idades gestacionais 12,5, 14,5 e 16,5 dias, para o marcador de células mesenquimais CD90

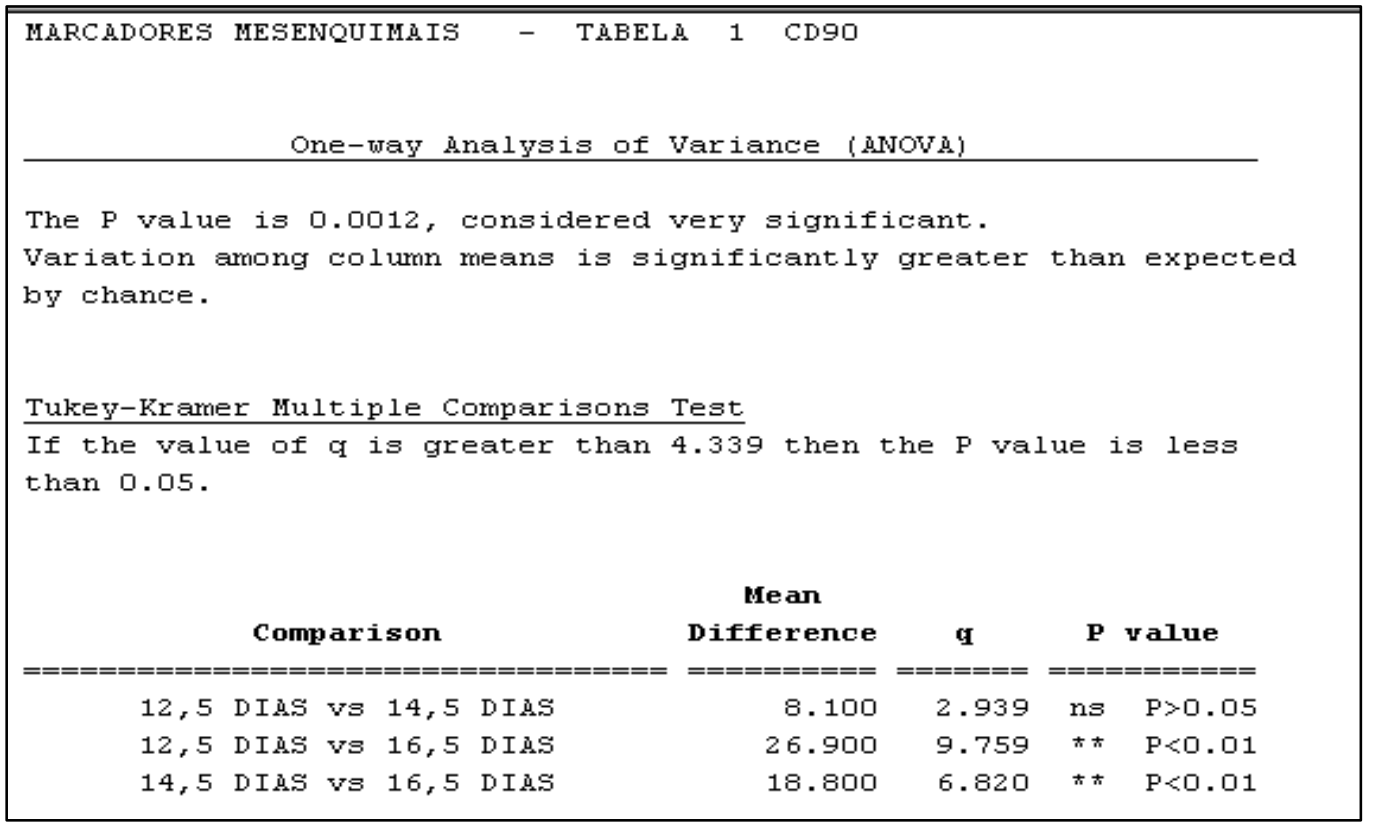

Apêndice D - Análise estatística do broto hepático de ratos Fischer 344 em diferentes idades gestacionais 12,5, 14,5 e 16,5 dias, para o marcador de células mesenquimais NANOG

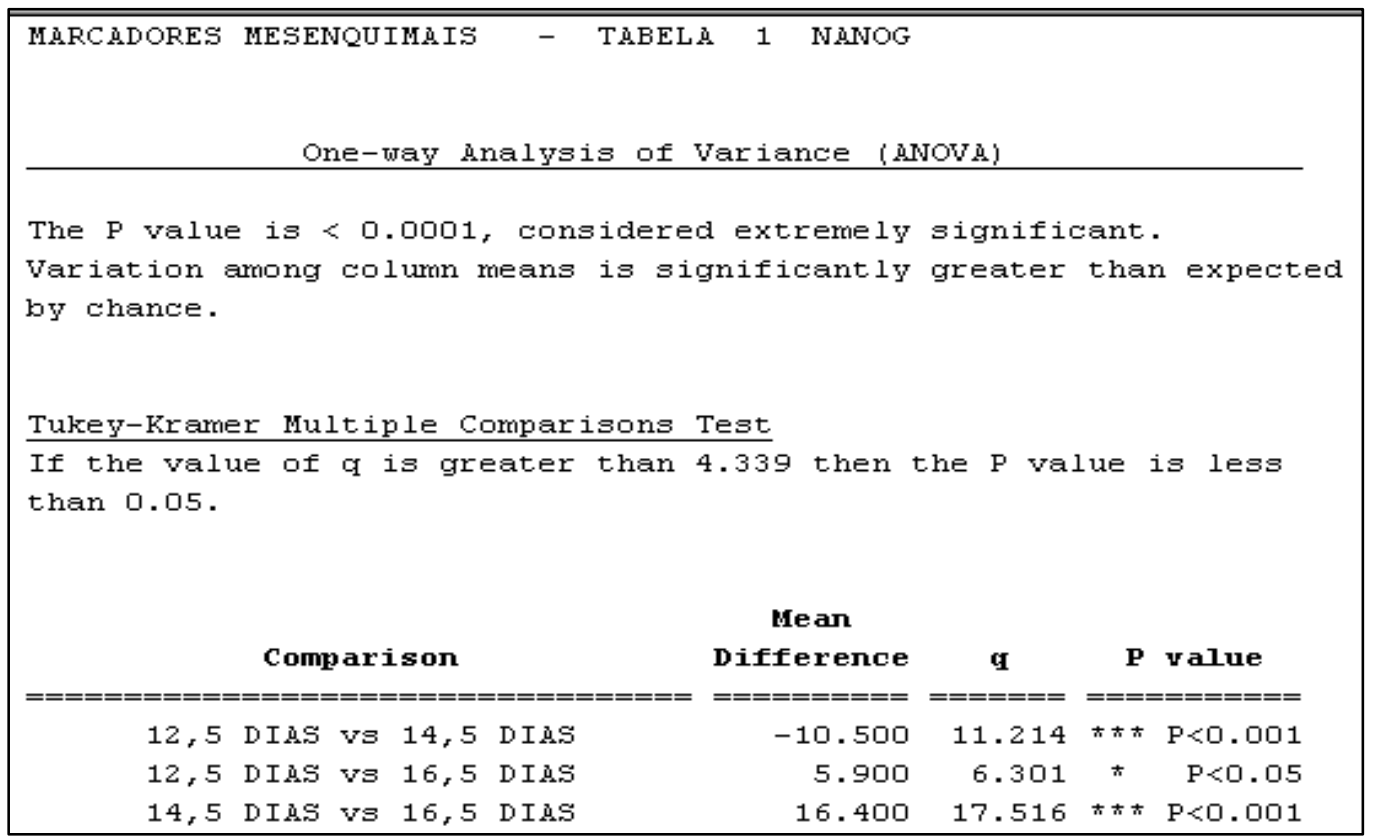


Apêndice E - Análise estatística do broto hepático de ratos Fischer 344 em diferentes idades gestacionais 12,5, 14,5 e 16,5 dias, para o marcador de células mesenquimais OCT3/4

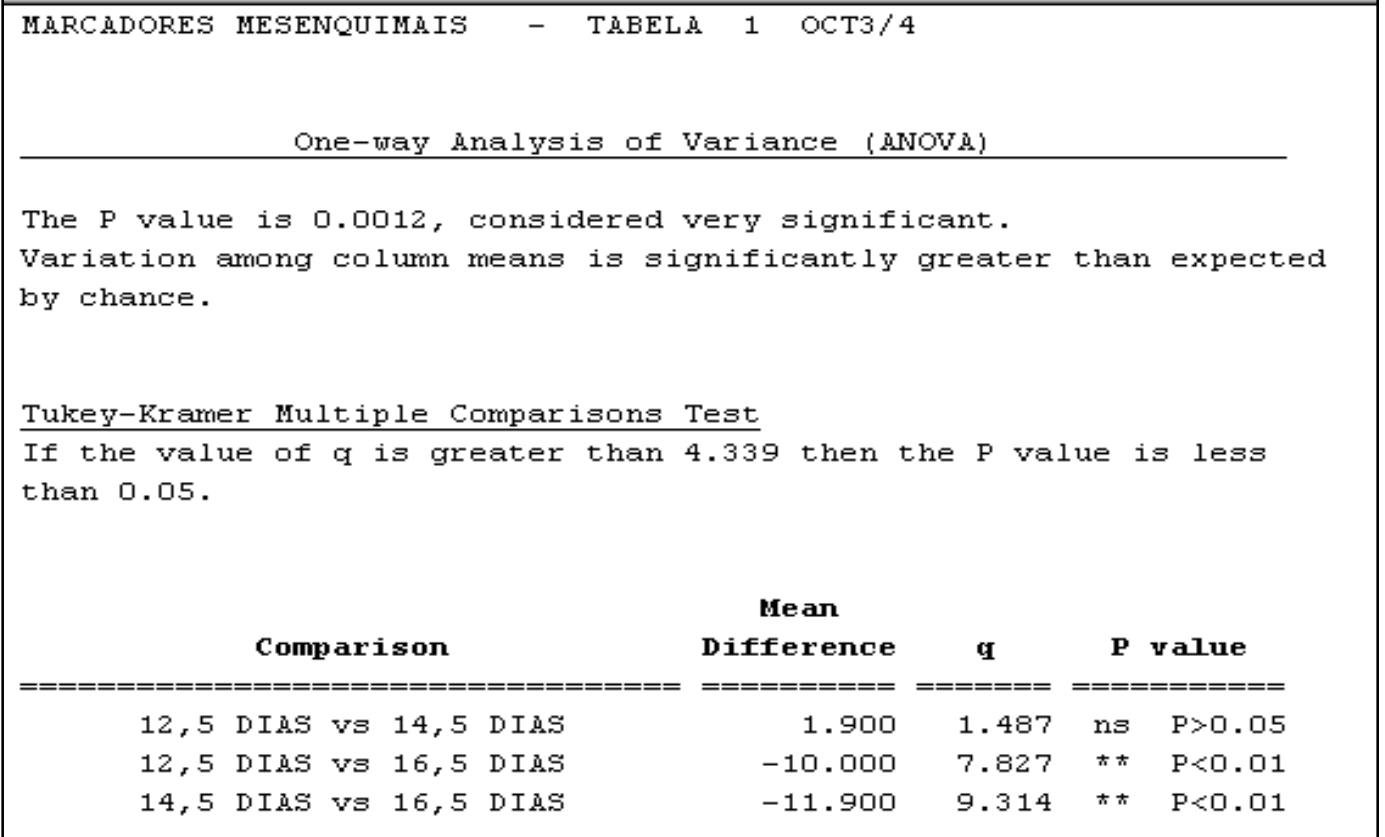

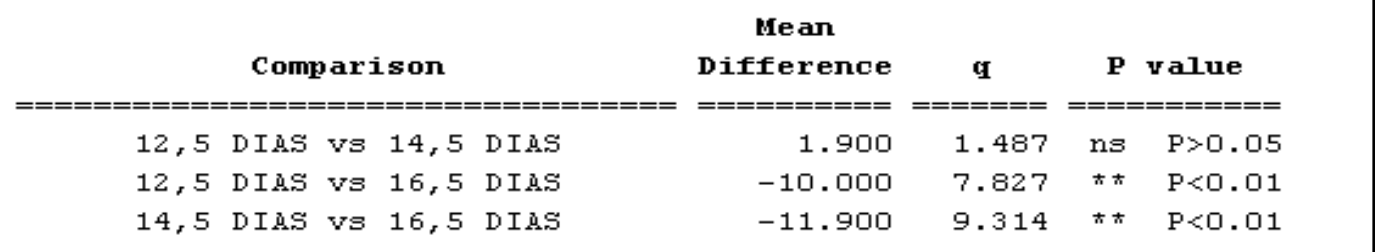

Apêndice F - Análise estatística do broto hepático de ratos Fischer 344 em diferentes idades gestacionais 12,5, 14,5 e 16,5 dias, para o marcador de células mesenquimais STRO-1

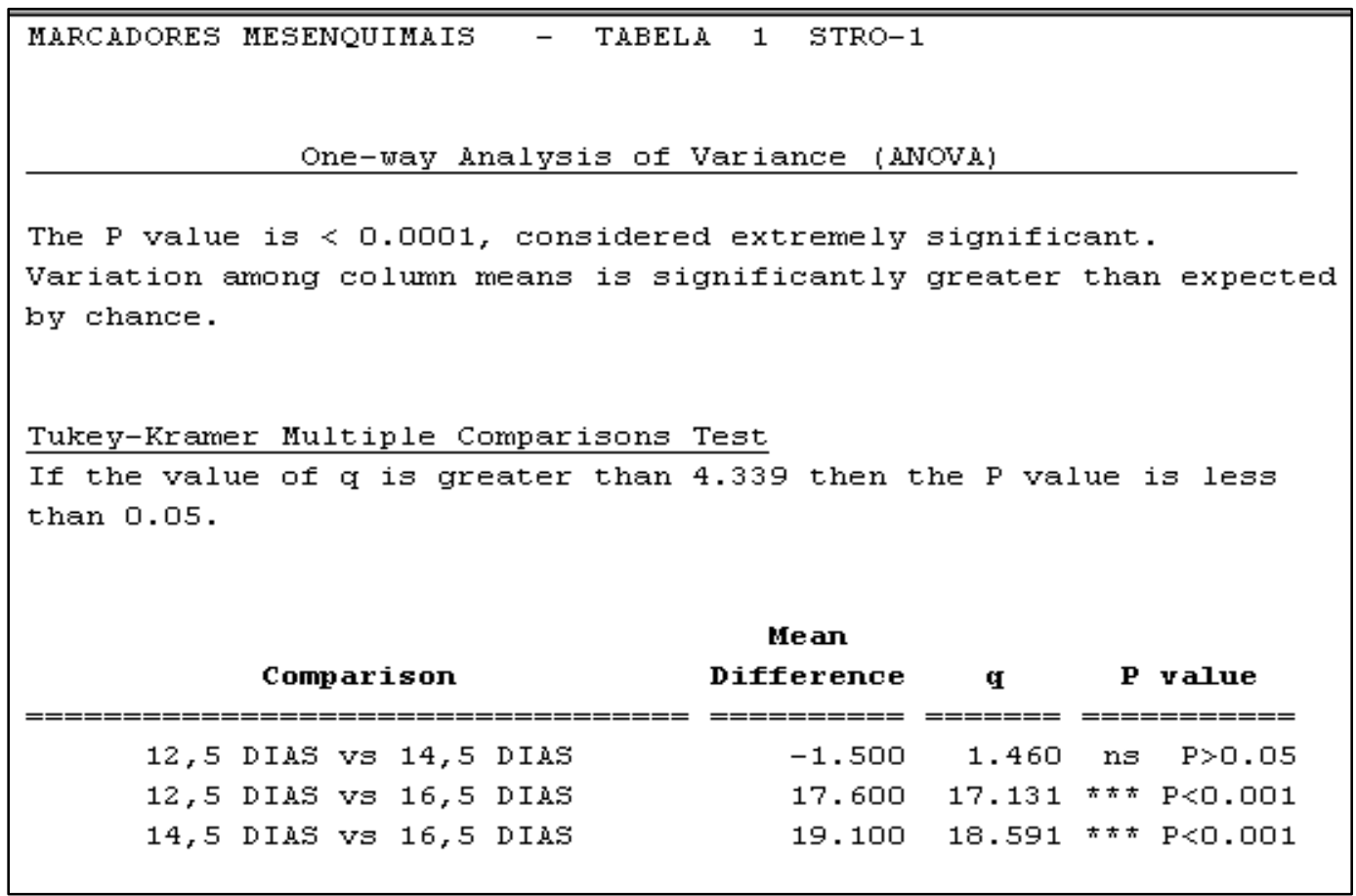


Apêndice G - Análise estatística do broto hepático de ratos Fischer 344 em diferentes idades gestacionais $12,5,14,5$ e 16,5 dias, para o marcador de citoesqueleto CK-8

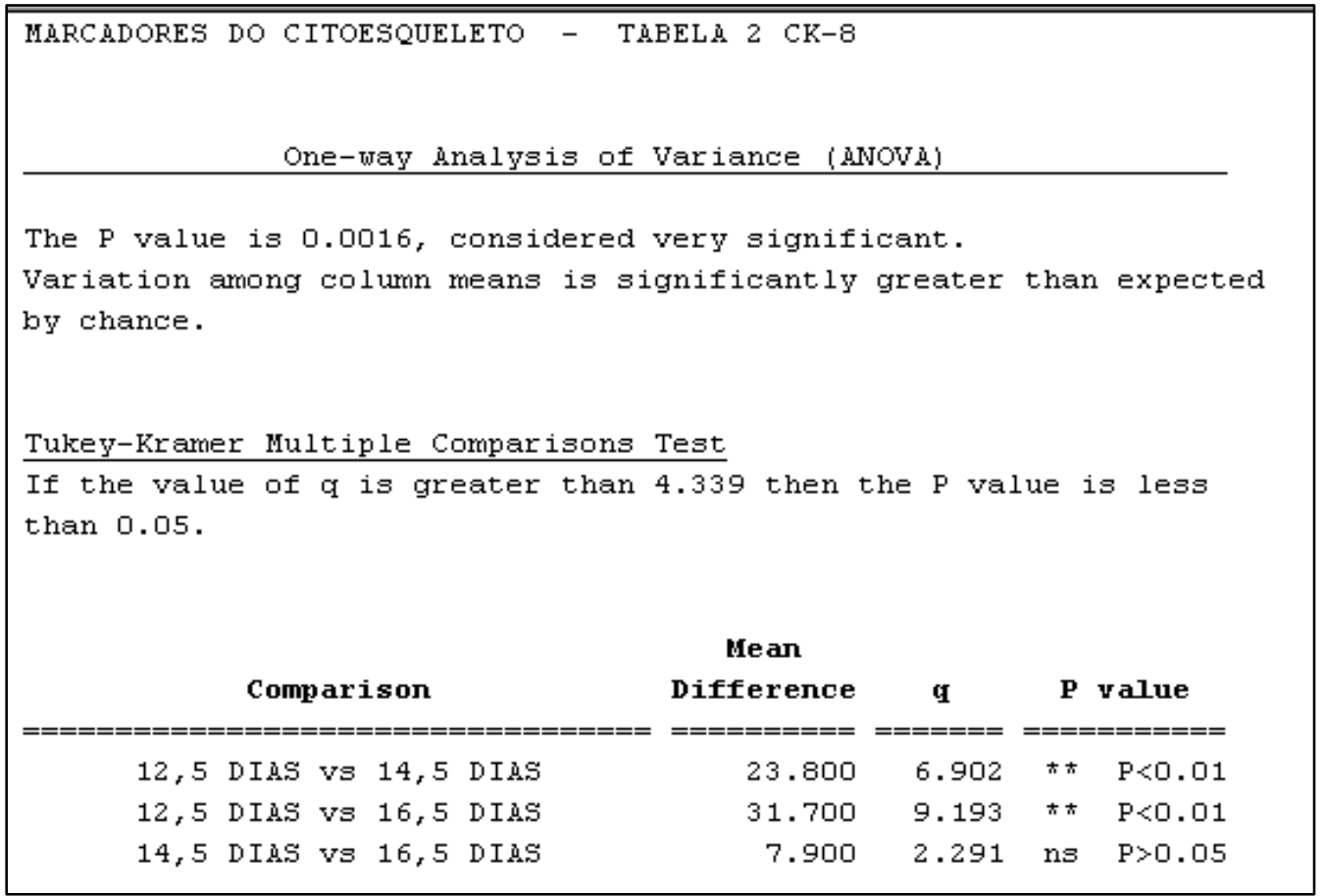

Apêndice H - Análise estatística do broto hepático de ratos Fischer 344 em diferentes idades gestacionais 12,5, 14,5 e 16,5 dias, para o marcador de citoesqueleto CK-18

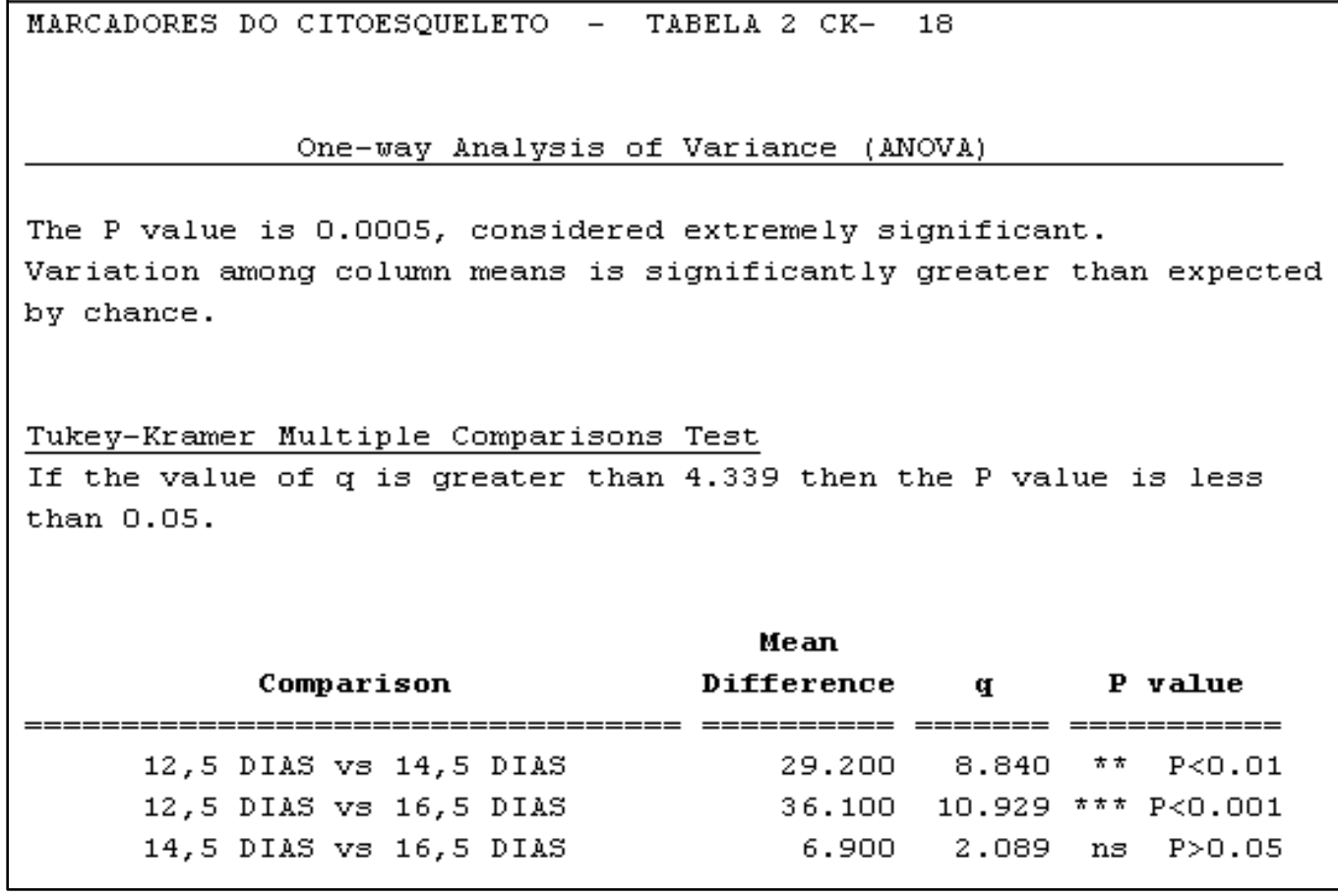

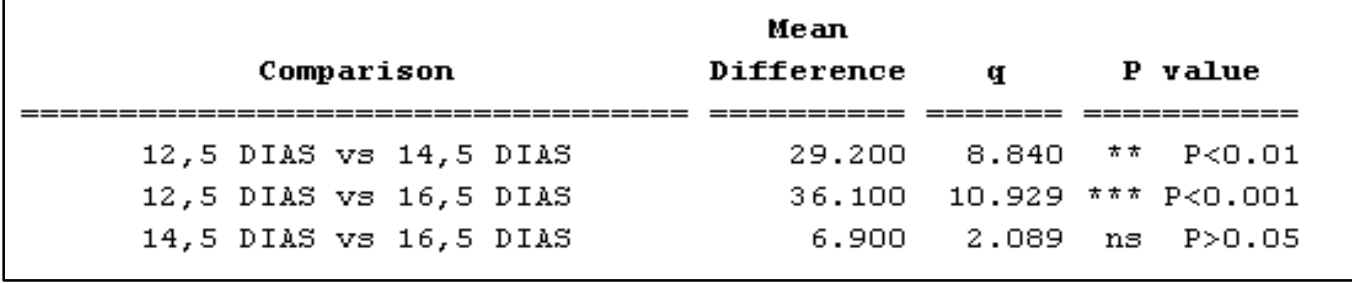


Apêndice I - Análise estatística do broto hepático de ratos Fischer 344 em diferentes idades gestacionais 12,5, 14,5 e 16,5 dias, para o marcador de citoesqueleto DESMINA

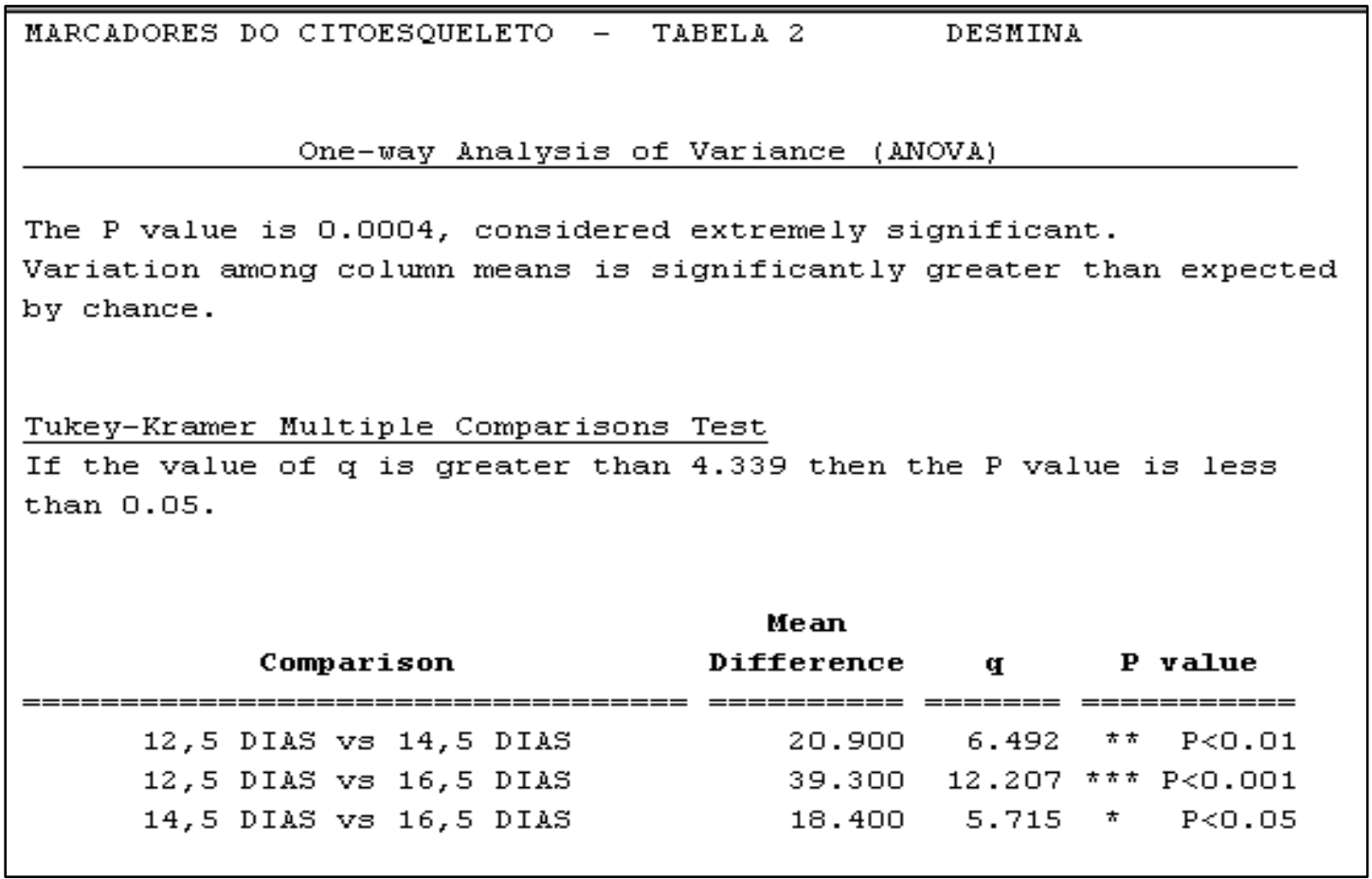

Apêndice J - Análise estatística do broto hepático de ratos Fischer 344 em diferentes idades gestacionais 12,5, 14,5 e 16,5 dias, para o marcador progressão do ciclo celular P53

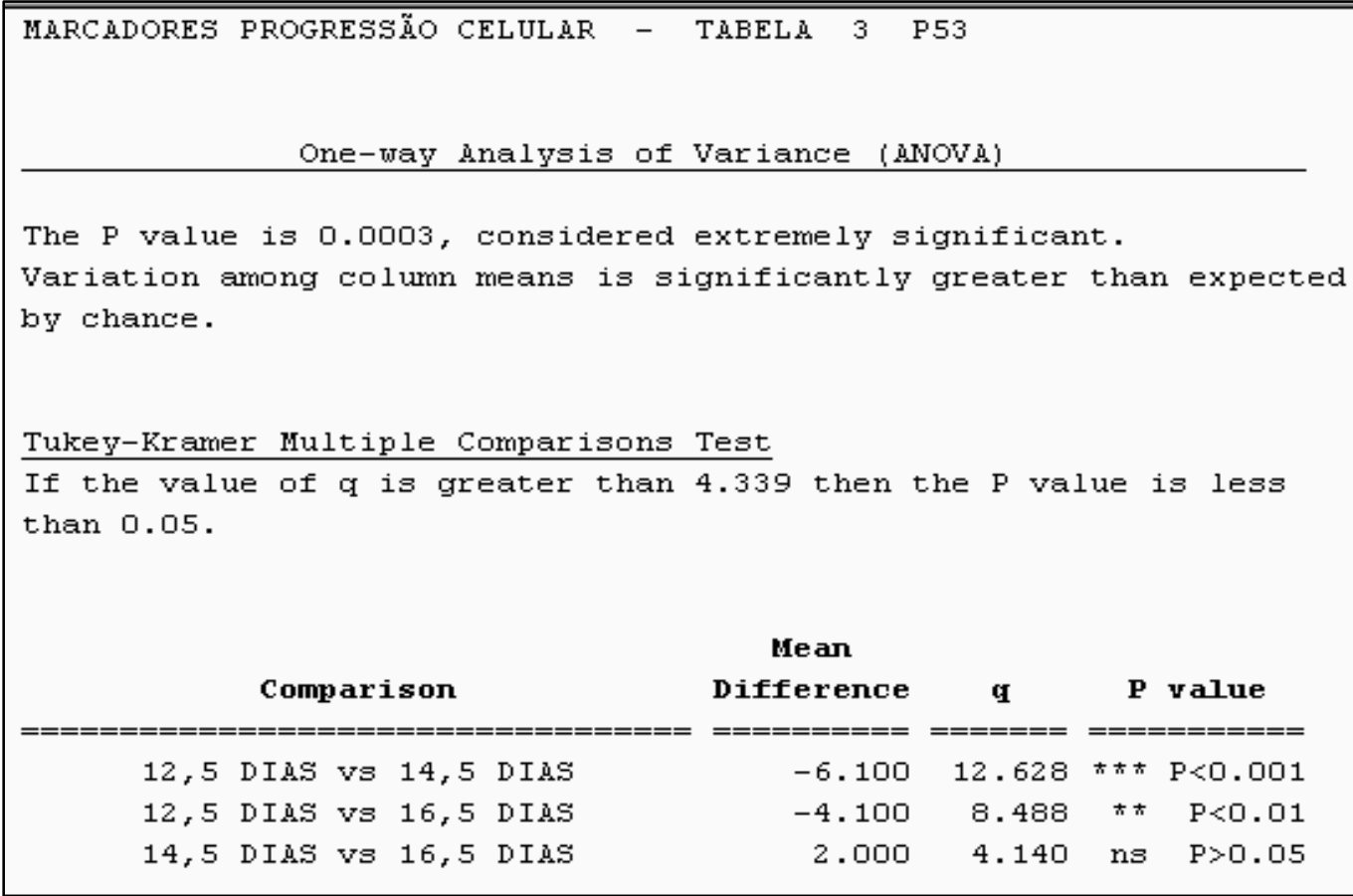

\section{Comparison}

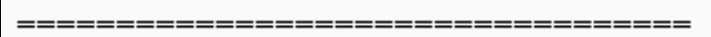

12,5 DIAS vs 14,5 DIAS

12,5 DIAS $v S 16,5$ DIAS

14,5 DIAS VS 16,5 DIAS

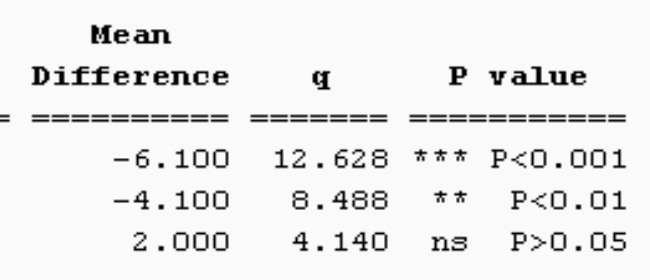


Apêndice K - Análise estatística do broto hepático de ratos Fischer 344 em diferentes idades gestacionais 12,5, 14,5 e 16,5 dias, para o marcador progressão do ciclo celular P21

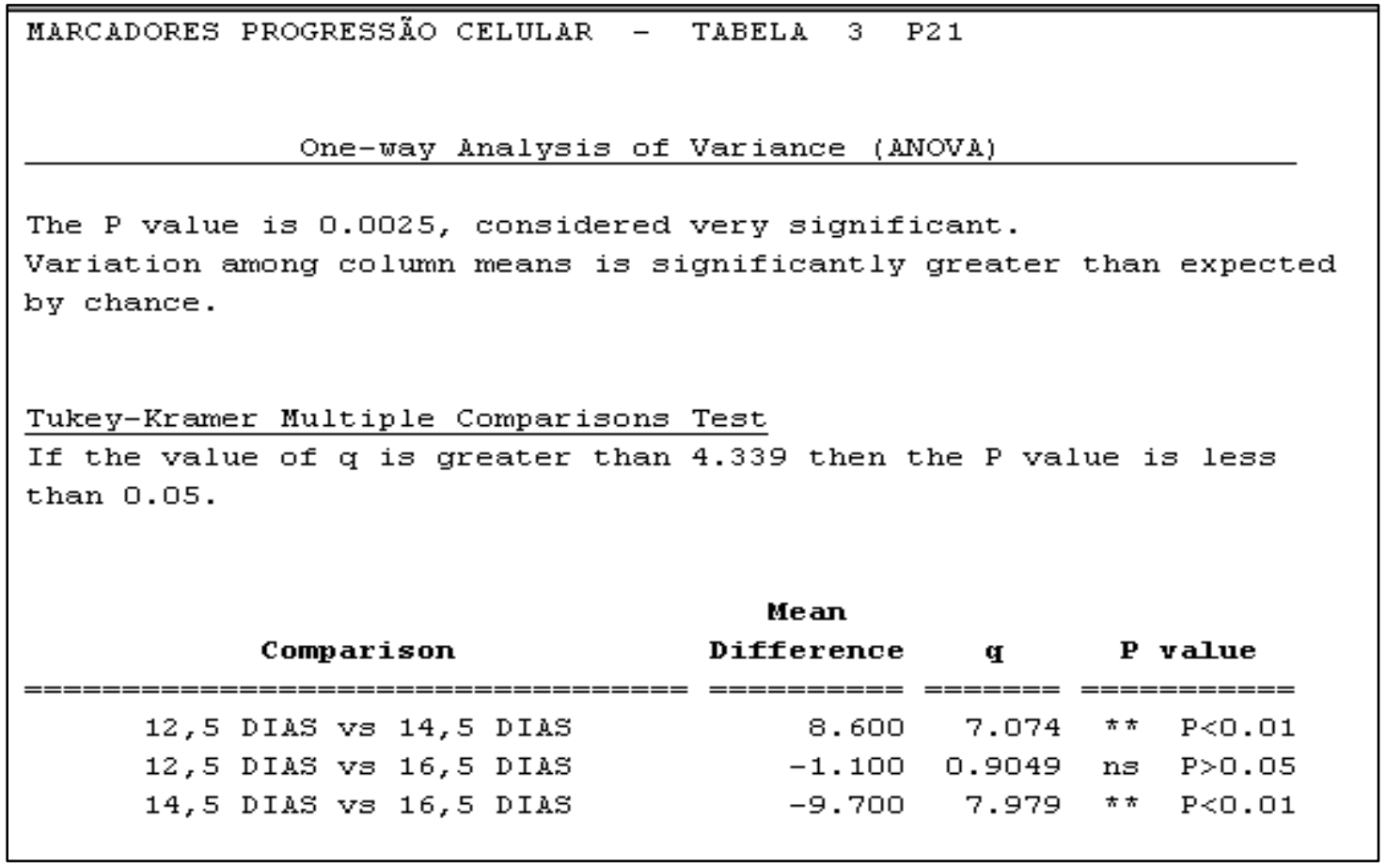

Apêndice L - Análise estatística do broto hepático de ratos Fischer 344 em diferentes idades gestacionais 12,5, 14,5 e 16,5 dias, para o marcador progressão do ciclo celular P27

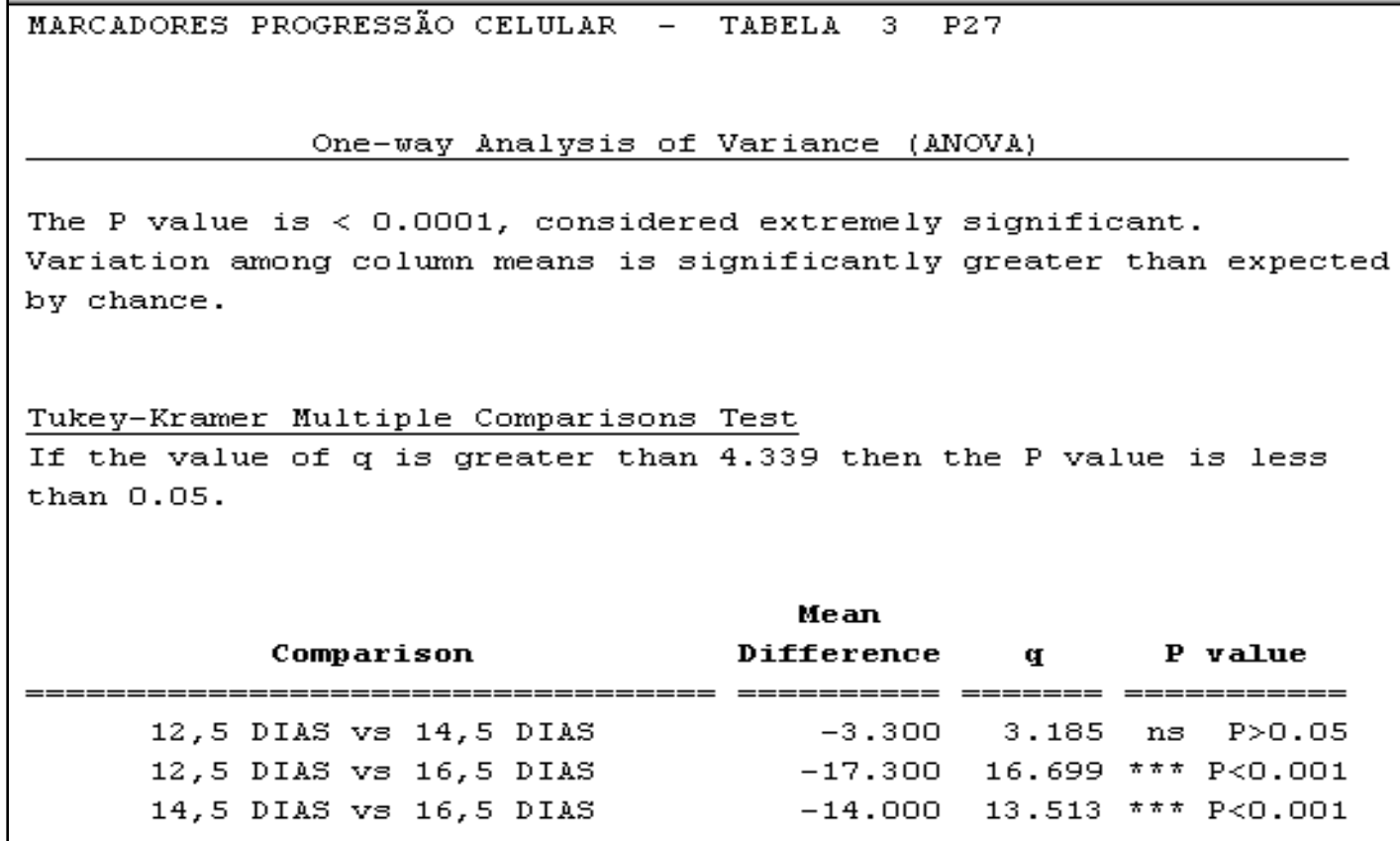

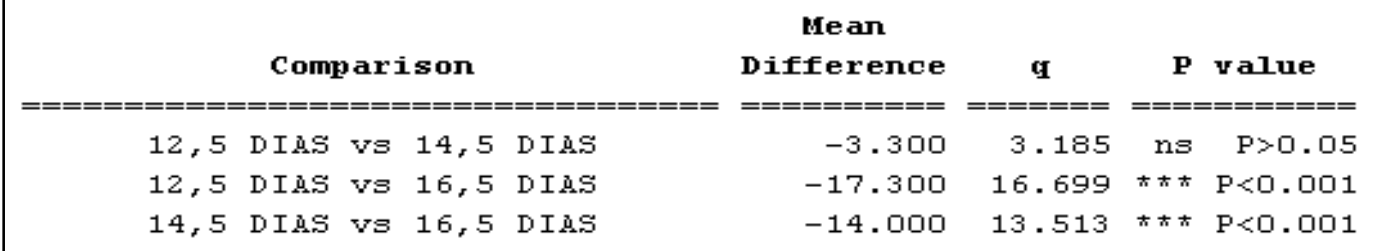


Apêndice M - Análise estatística do broto hepático de ratos Fischer 344 em diferentes idades gestacionais 12,5, 14,5 e 16,5 dias, para o marcador progressão do ciclo celular CICLINA D1

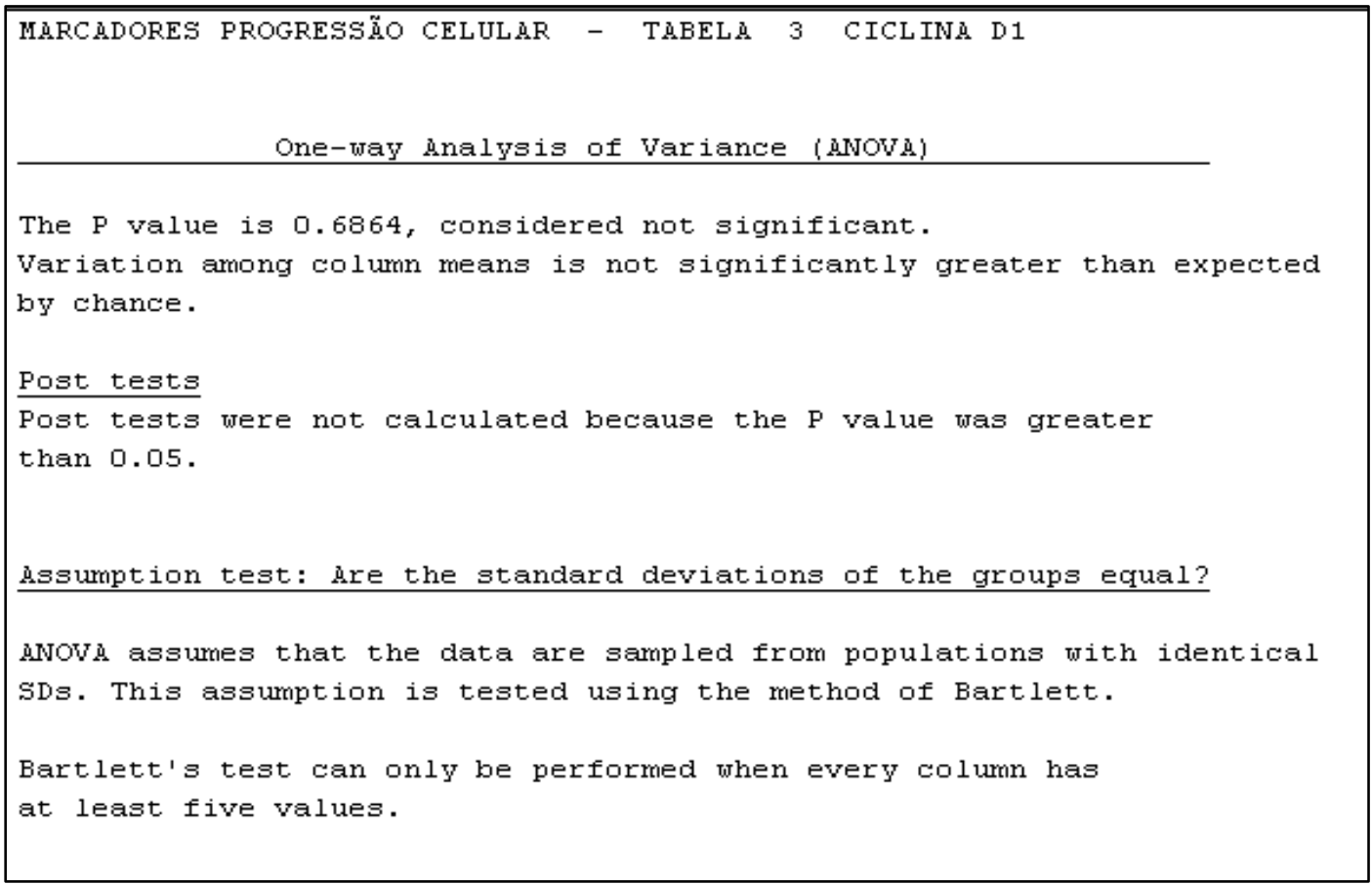

Apêndice N - Análise estatística do broto hepático de ratos Fischer 344 em diferentes idades gestacionais 12,5, 14,5 e 16,5 dias, para o marcador de vias de morte celular ANEXINA V

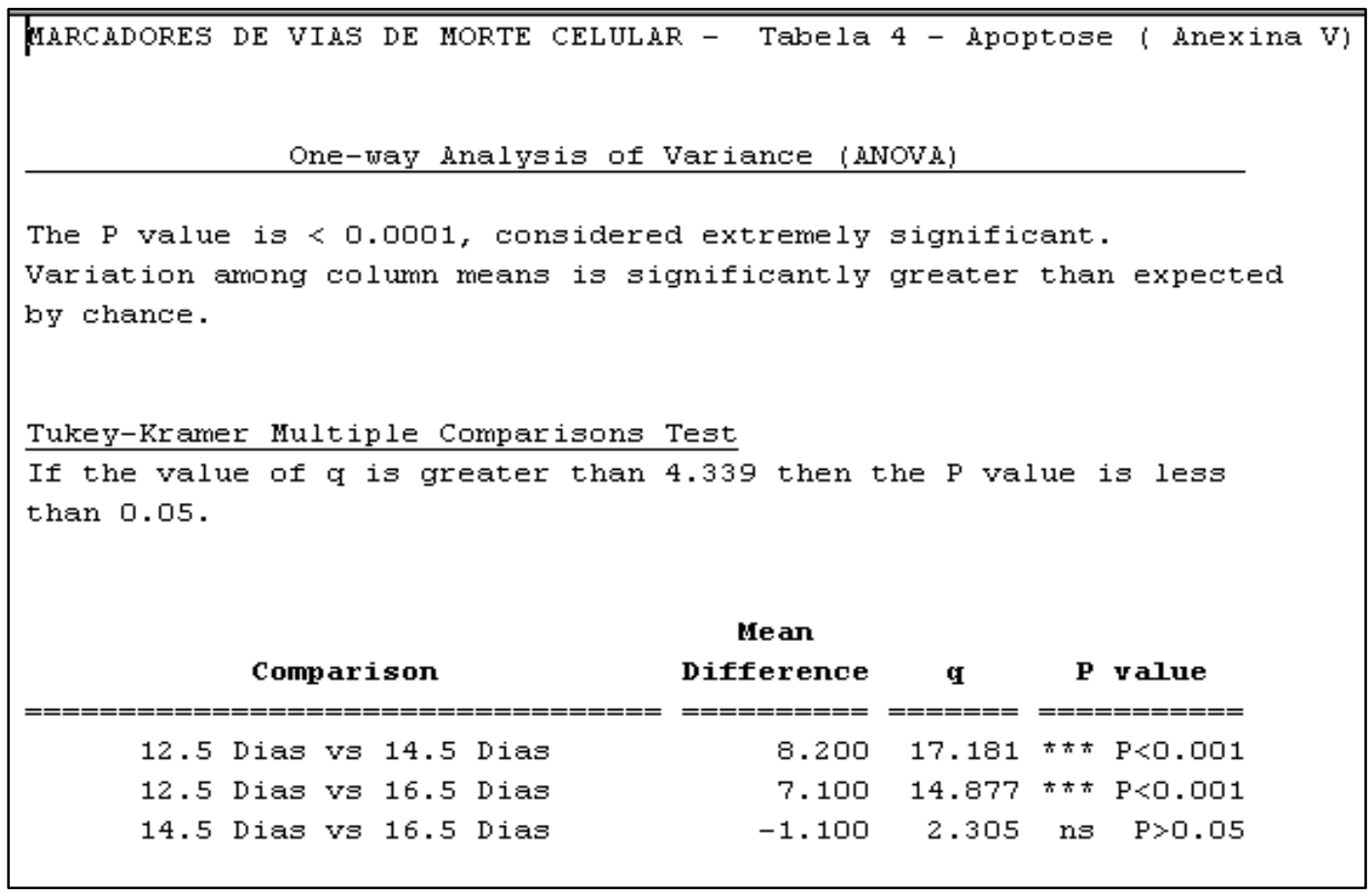


Apêndice O - Análise estatística do broto hepático de ratos Fischer 344 em diferentes idades gestacionais 12,5, 14,5 e 16,5 dias, para o marcador de morte celular PI

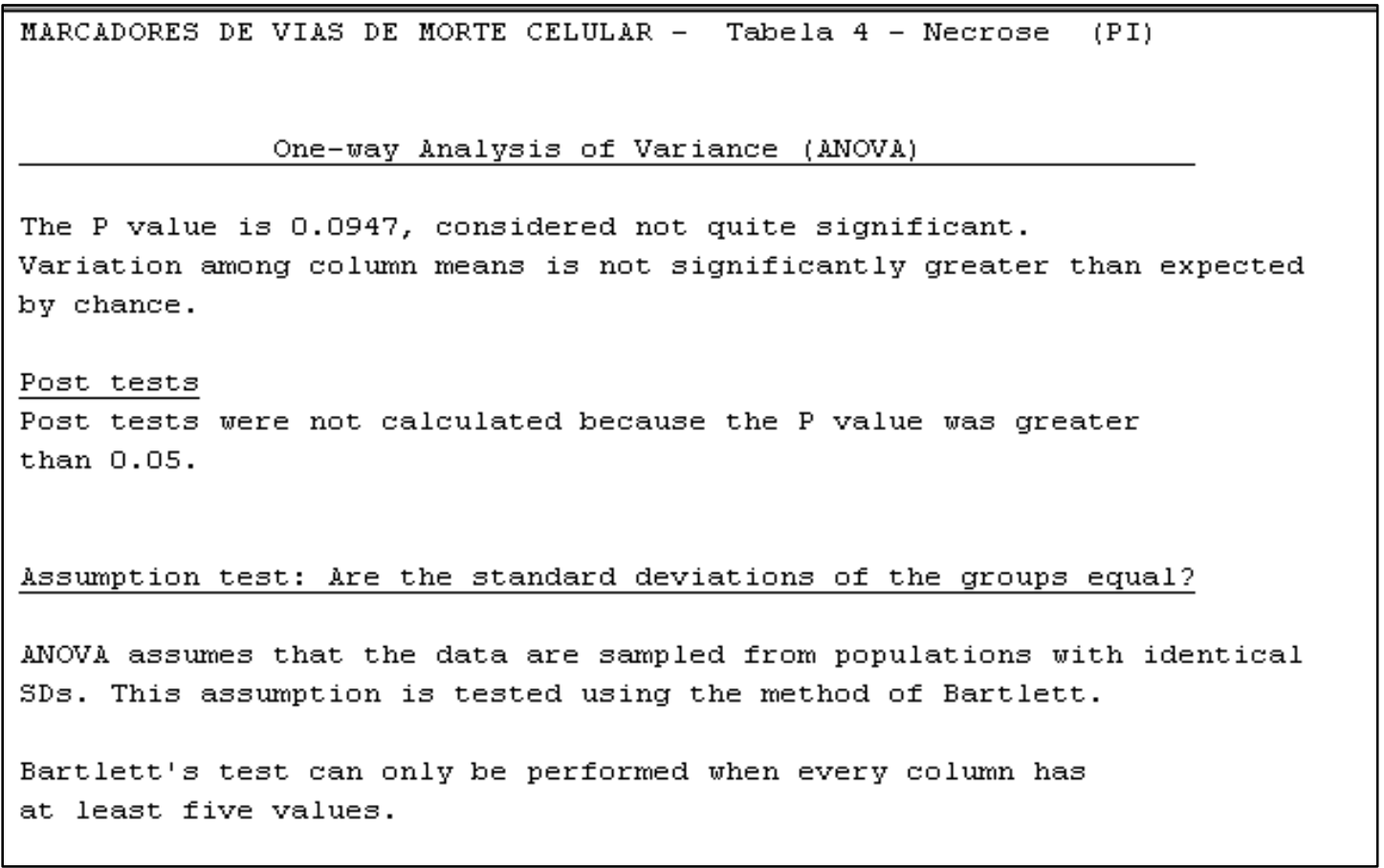

Apêndice P - Análise estatística do broto hepático de ratos Fischer 344 em diferentes idades gestacionais 12,5, 14,5 e 16,5 dias, para o marcador de morte celular CASPASE 3

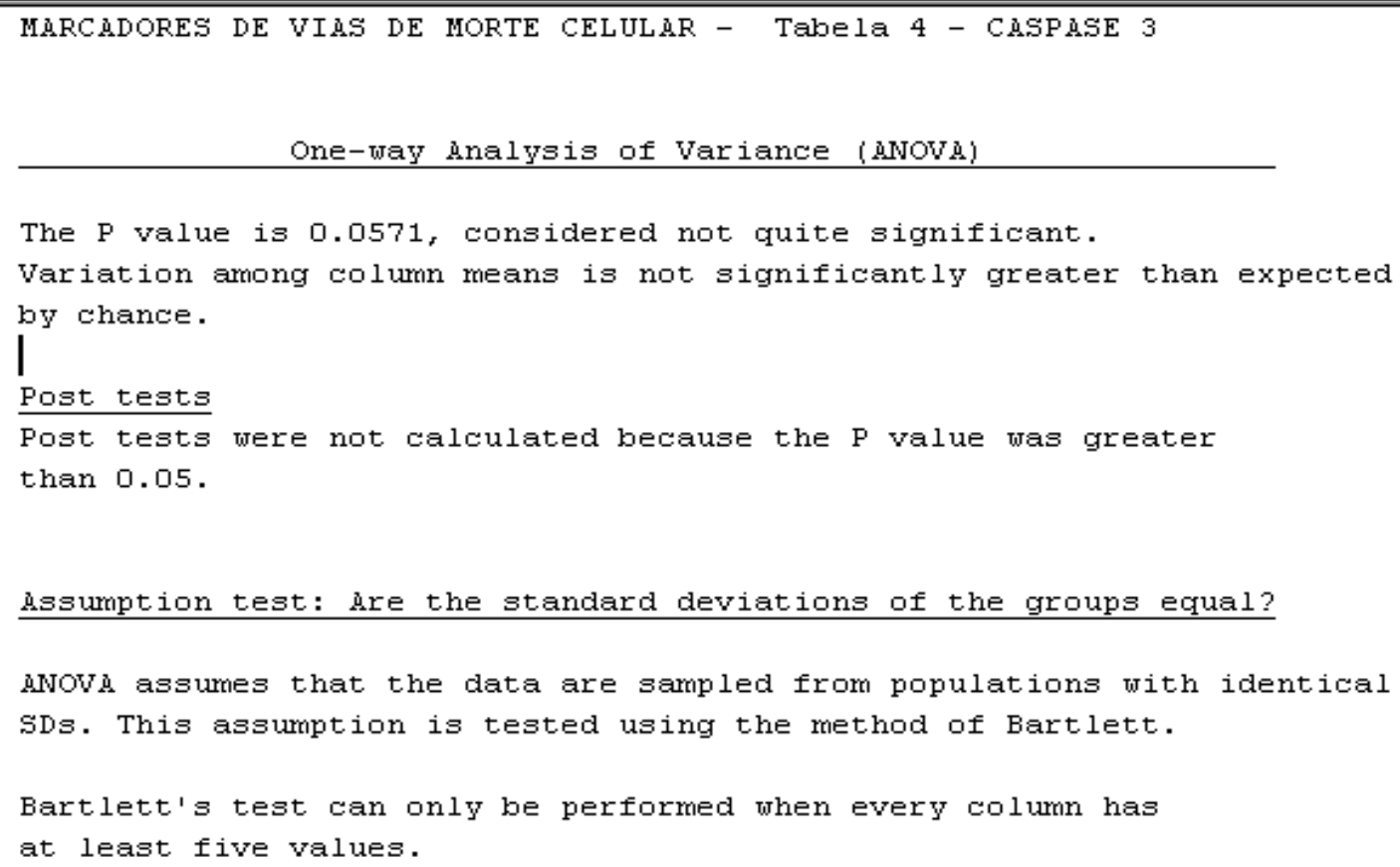


Apêndice Q - Análise estatística do broto hepático de ratos Fischer 344 em diferentes idades gestacionais 12,5, 14,5 e 16,5 dias, para o marcador de vias de morte celular BAX

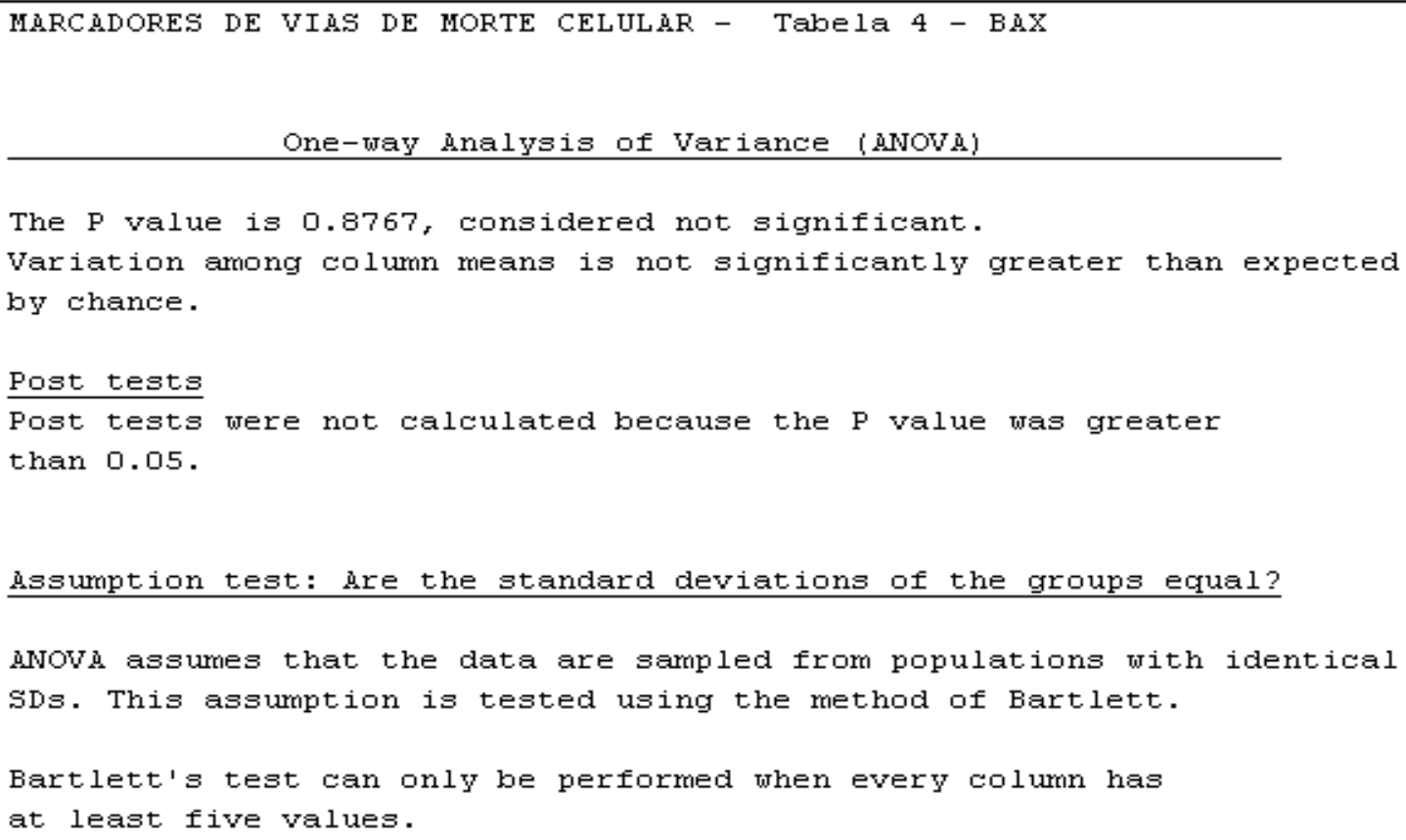

Apêndice R - Análise estatística do broto hepático de ratos Fischer 344 em diferentes idades gestacionais 12,5, 14,5 e 16,5 dias, para o marcador de morte celular BAD

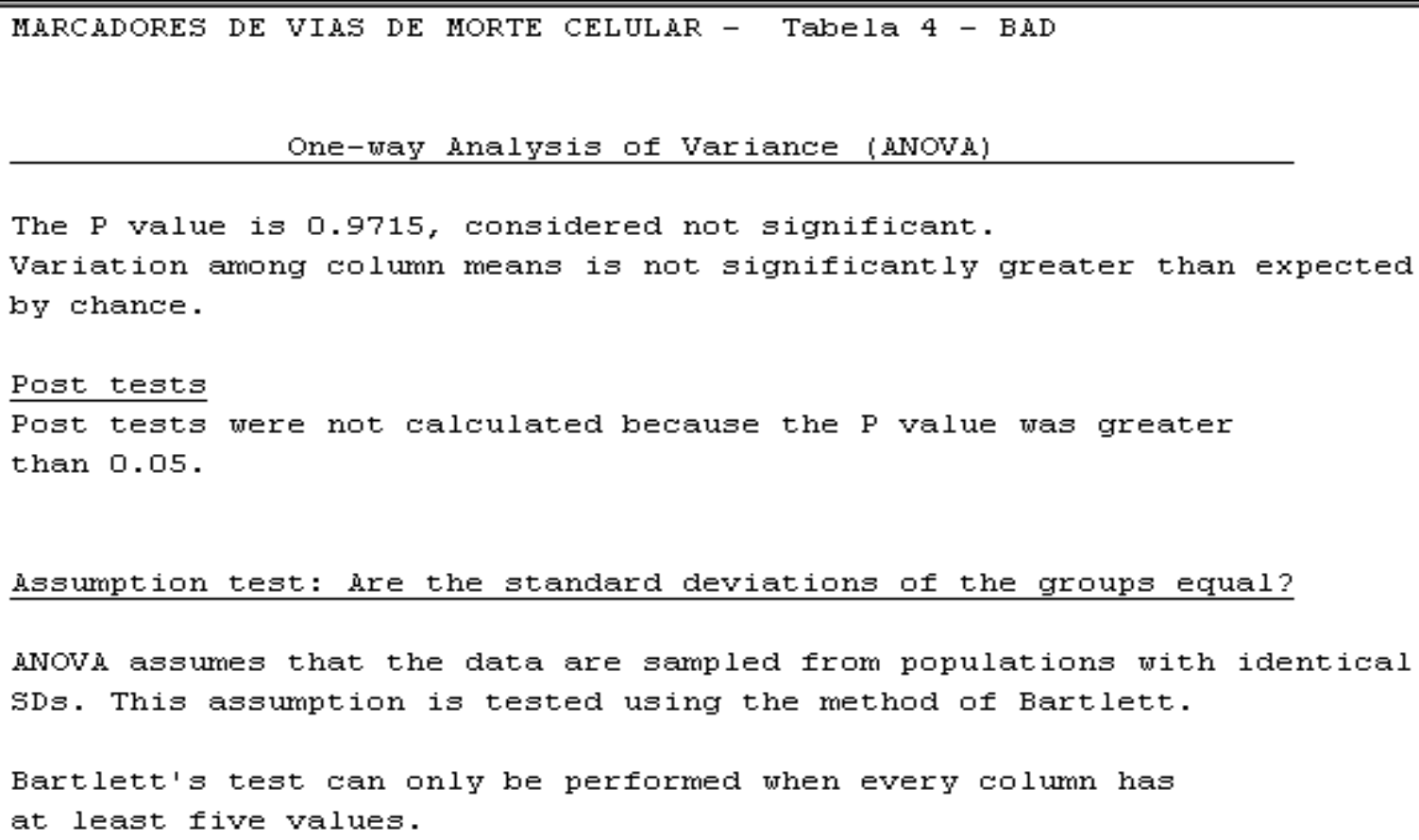


Apêndice S - Análise estatística do broto hepático de ratos Fischer 344 em diferentes idades gestacionais 12,5, 14,5 e 16,5 dias, para o marcador de vias de morte celular BCL-2

MARCADORES DE VIAS DE MORTE CELULAR - Tabela 4 - BCL-2

The $P$ value is 0.10 .52 , considered not significant.

Variation arong colum raeans is not significantly greater than expected by chance.

1

Past tests

Post tests were ngt calculated because the F value was greater

than D. $\square .5$.

Ảsurption test: Ảre the standard deviations af the graups equal?

ưowh assumes that the data are sempled from populations with identical

sDs. This assurptian is tested using the ruethod af Bart.lett.

Bartlet.' 3 test. can anly be performed when every colum has

at least five values. 
Apêndice T - Análise estatística do broto hepático de ratos Fischer 344 em diferentes idades gestacionais 12,5, 14,5 e 16,5 dias, para o marcador de citoesqueleto CK-18

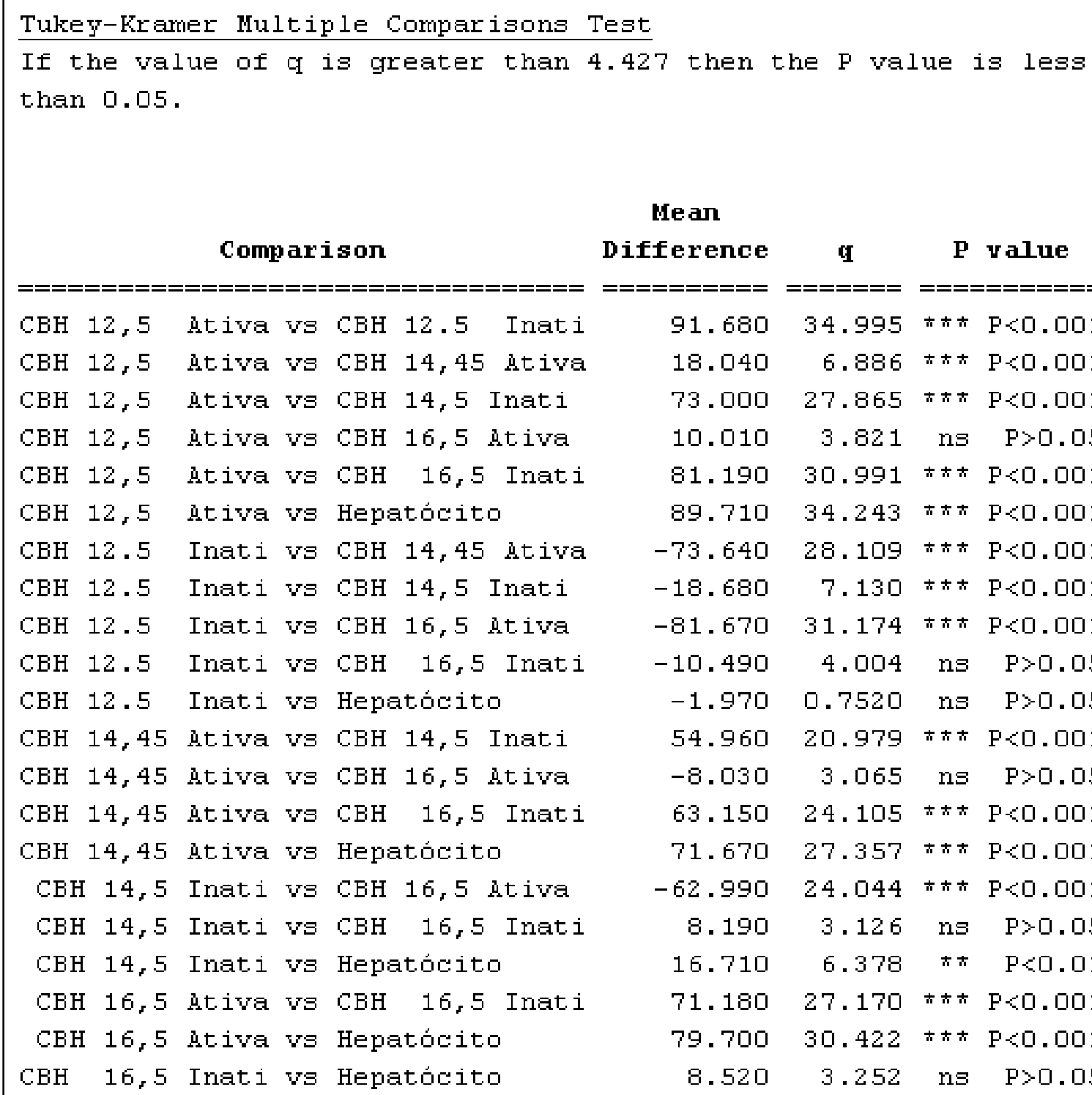

Mean Difference

$=======$

8. 520 
Apêndice U - Análise estatística do broto hepático de ratos Fischer 344 em diferentes idades gestacionais 12,5, 14,5 e 16,5 dias, para o ciclo celular na fase G0/G1

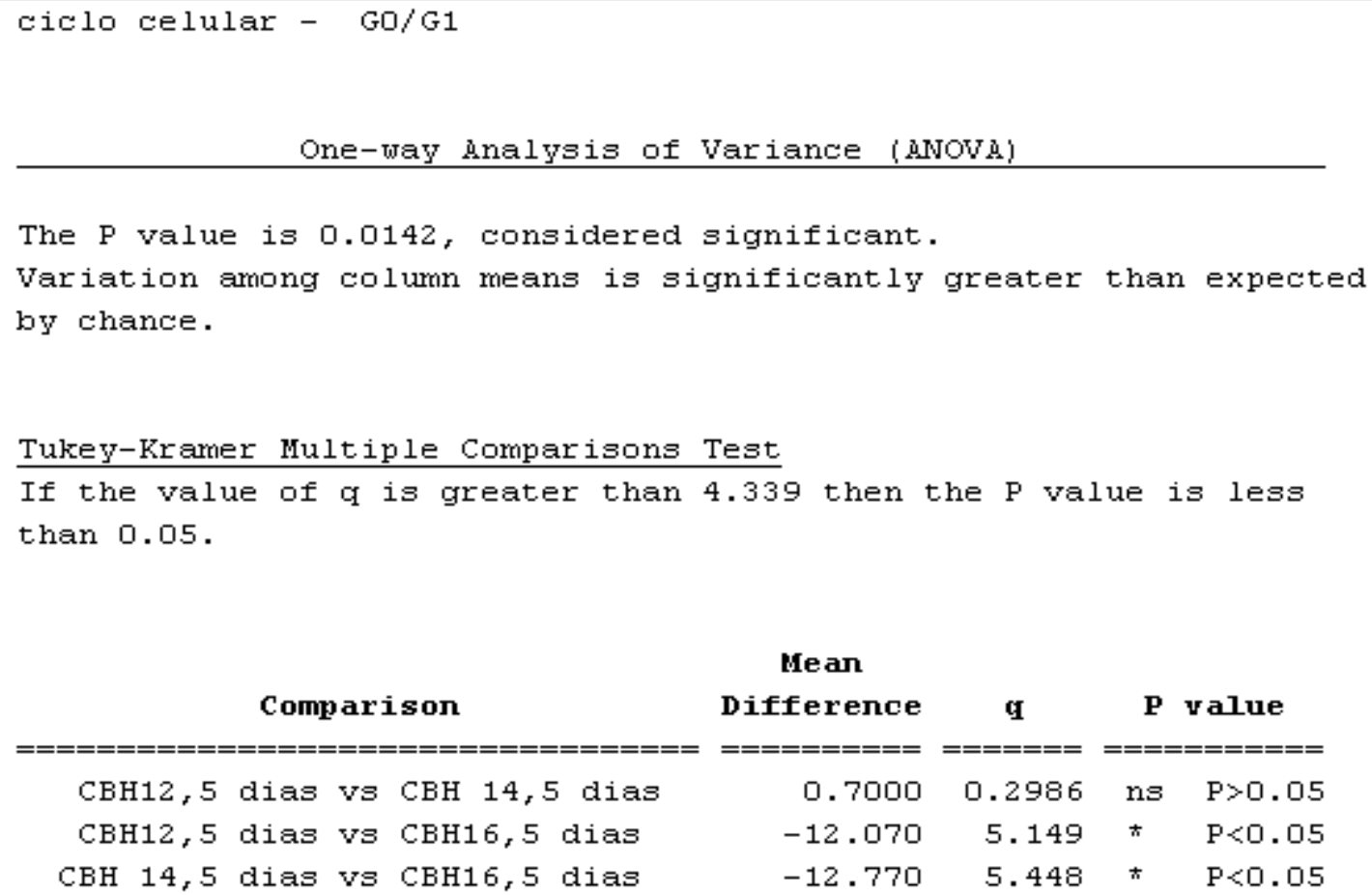

Apêndice V - Análise estatística do broto hepático de ratos Fischer 344 em diferentes idades gestacionais 12,5, 14,5 e 16,5 dias, para o ciclo celular na fase $\mathrm{S}$

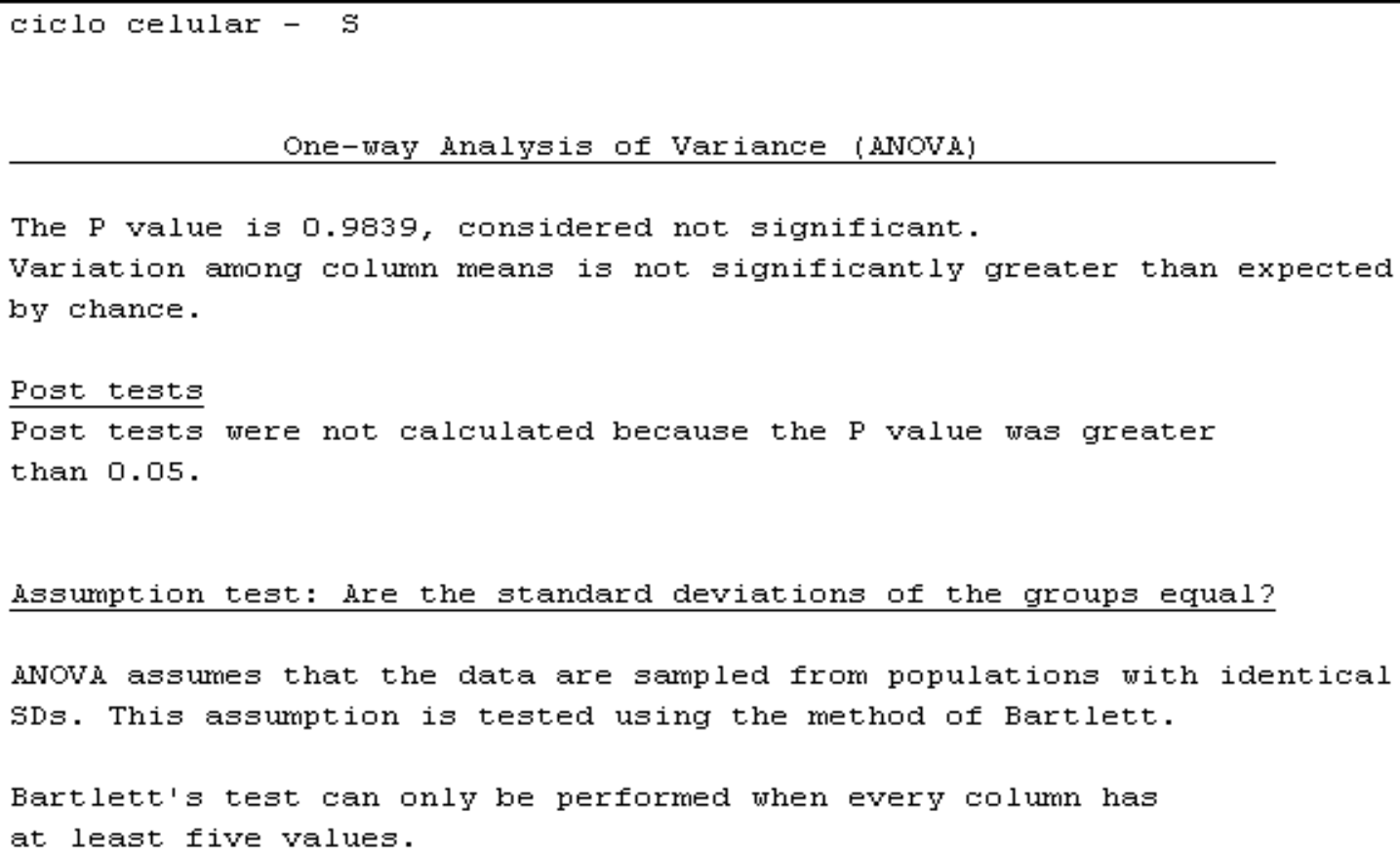


Apêndice W - Análise estatística do broto hepático de ratos Fischer 344 em diferentes idades gestacionais 12,5, 14,5 e 16,5 dias, para o ciclo celular na fase G2/M

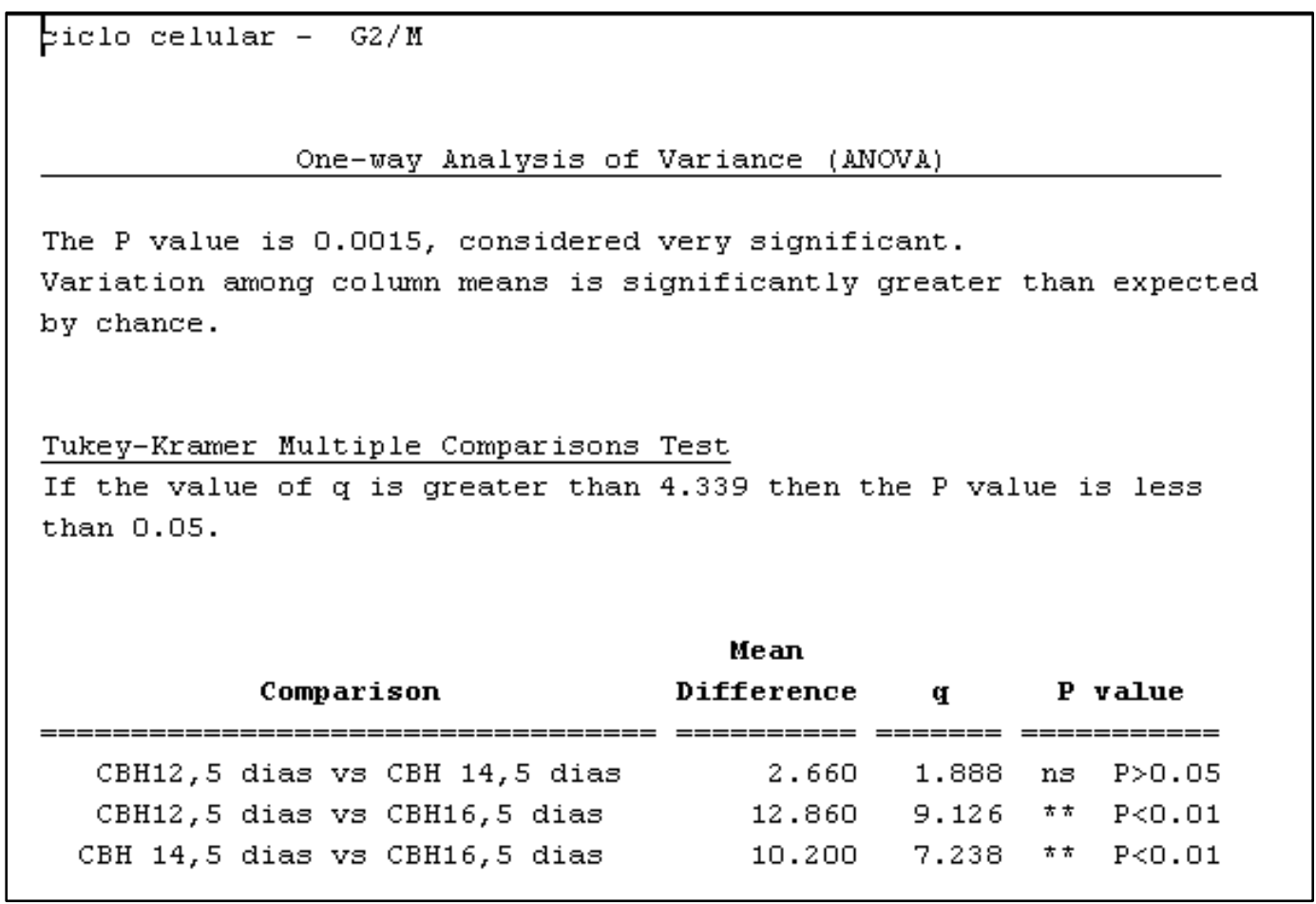

Apêndice X - Análise estatística do broto hepático de ratos Fischer 344 em diferentes idades gestacionais 12,5, 14,5 e 16,5 dias, para o ciclo celular na fase DNA fragmentado

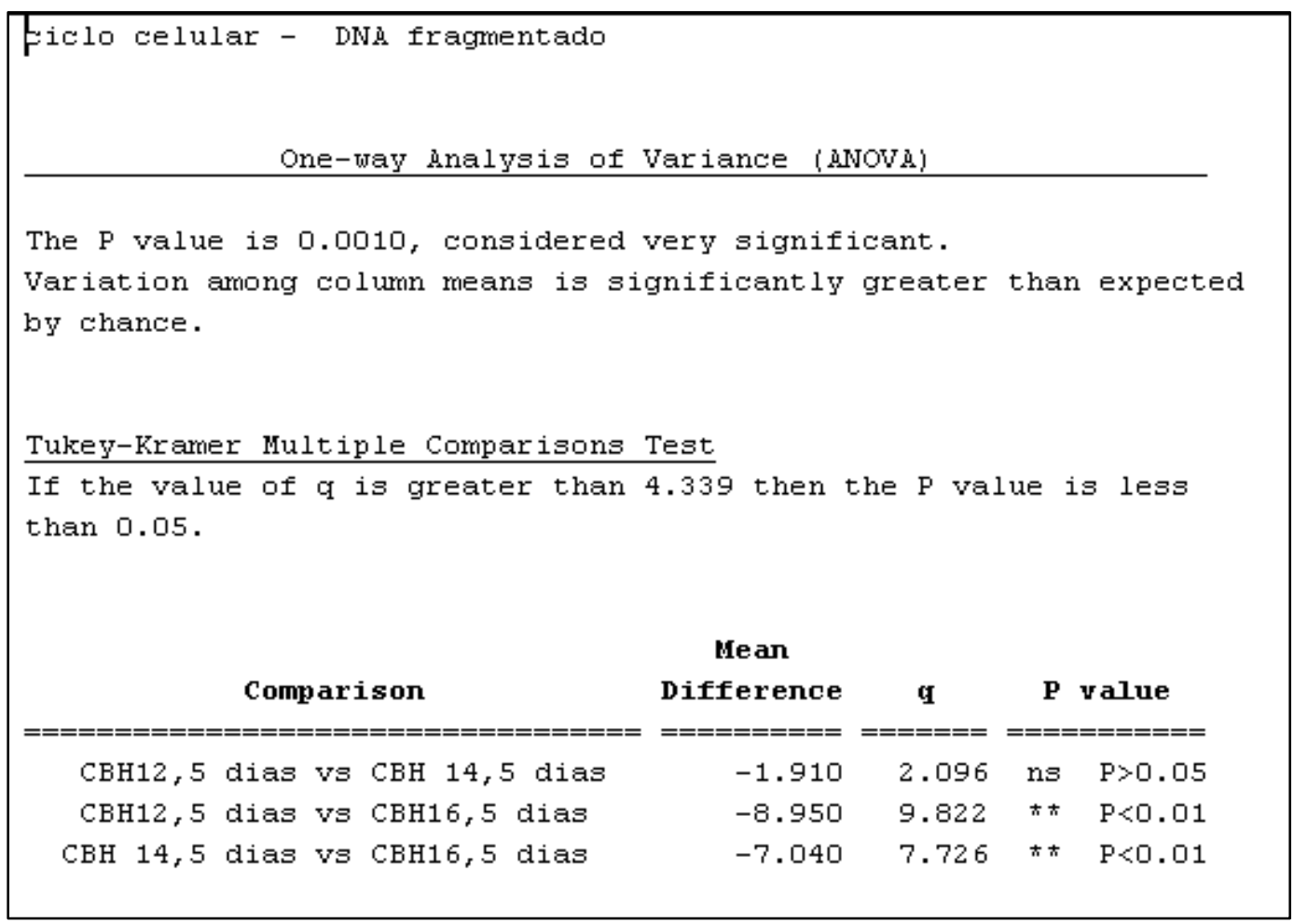


Apêndice Y - Análise estatística do broto hepático de ratos Fischer 344 em diferentes idades gestacionais 12,$5 ; 14,5$ e 16,5 dias, para LPO

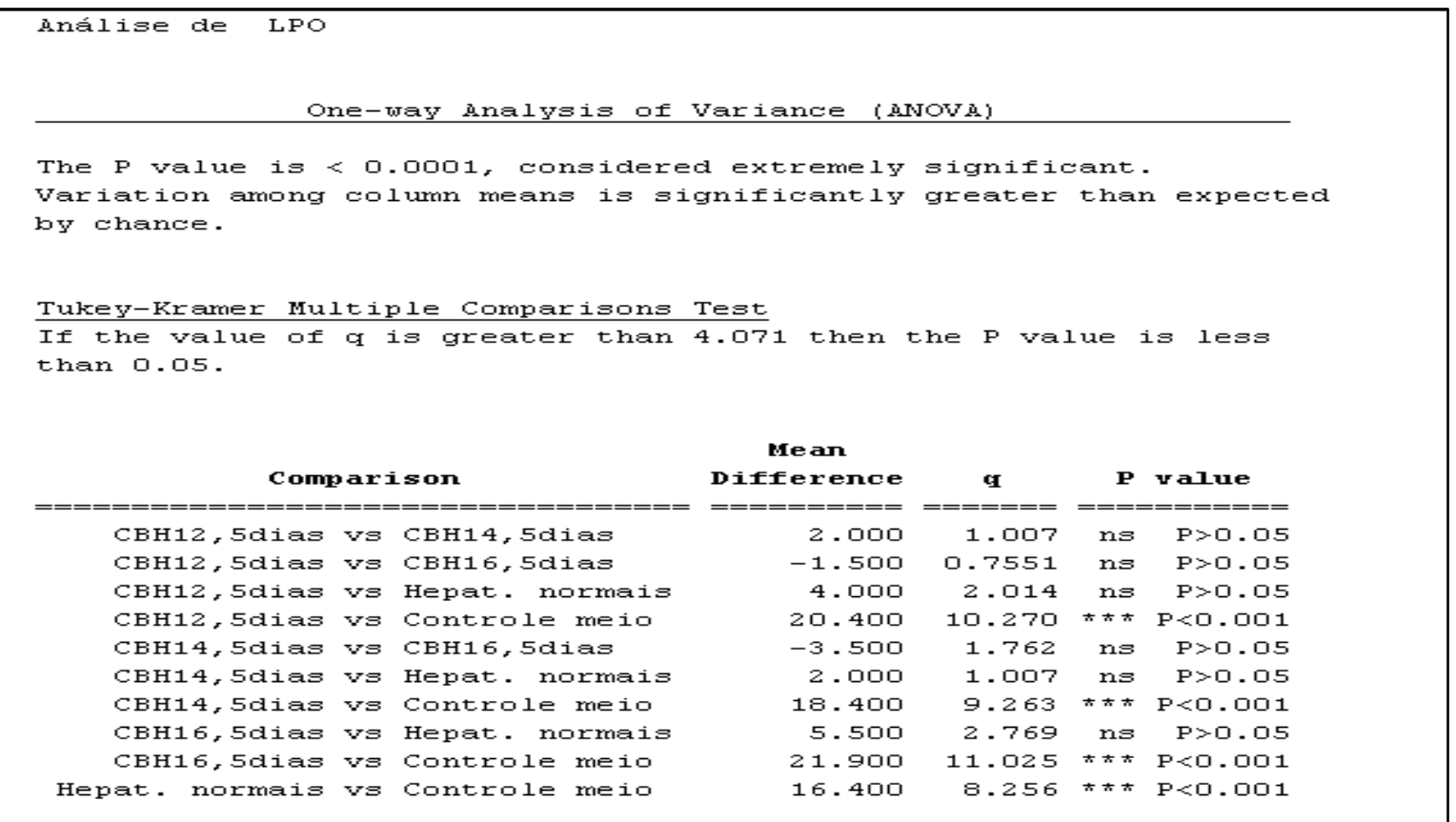

Apêndice Z - Curva padrão bradford

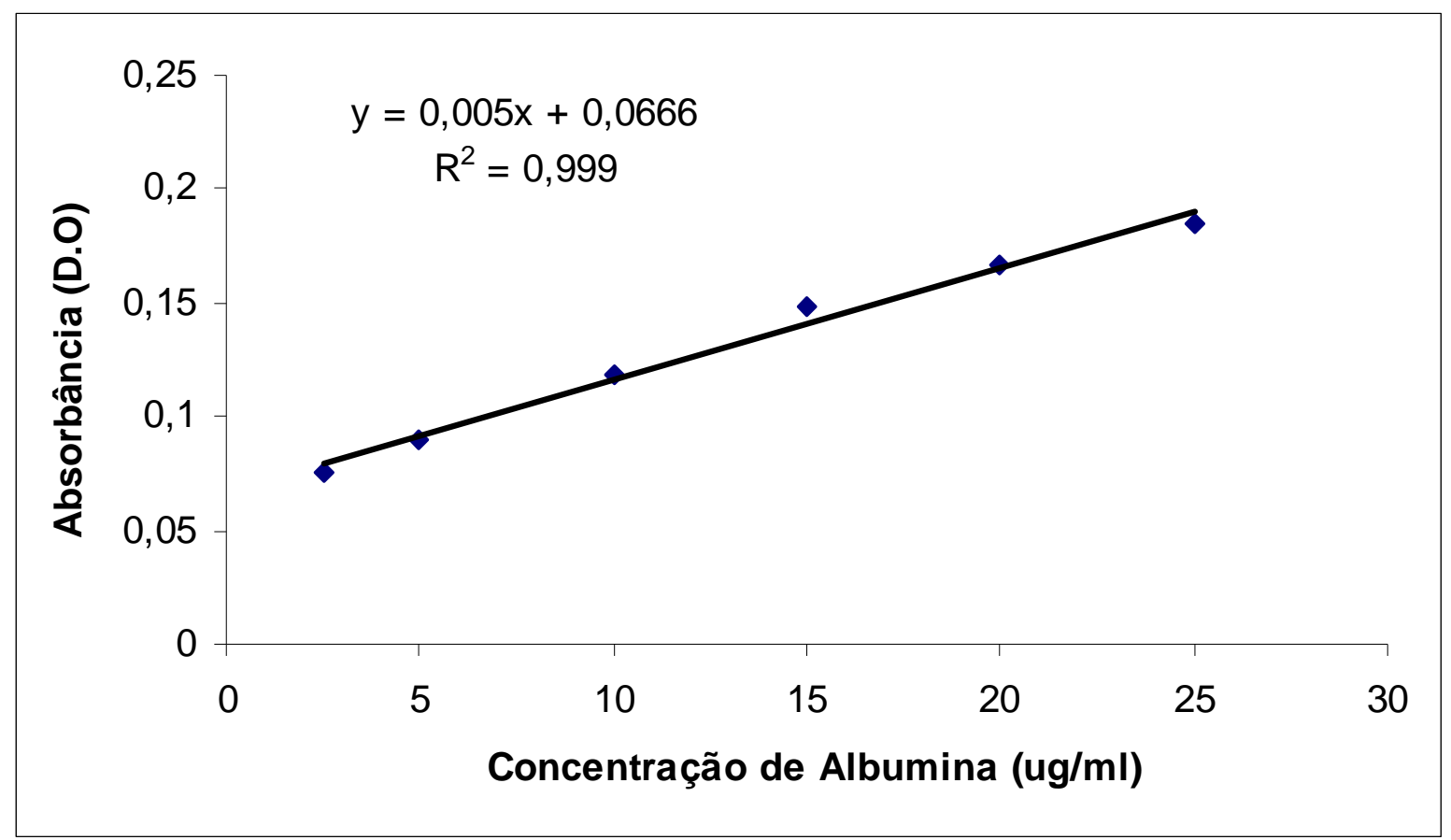

